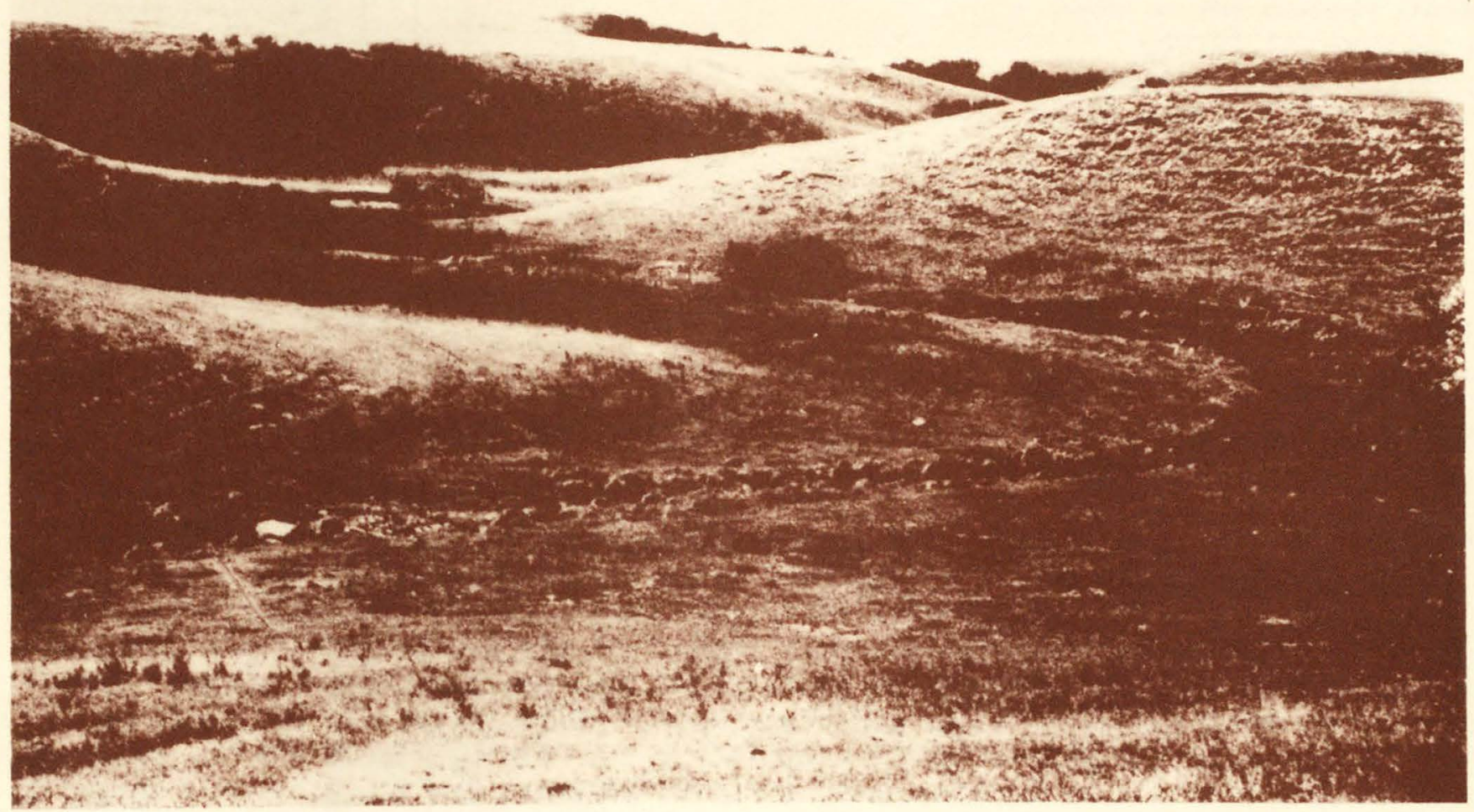

\title{
HYDROLOGIC CHARACTERISTICS AND POSSIBLE EFFECTS OF SURFACE MINING IN THE NORTHWESTERN PART OF WEST BRANCH ANTELOPE CREEK BASIN, MERCER COUNTY, NORTH DAKOTA
}

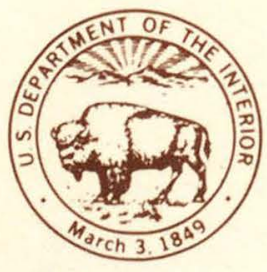




\begin{tabular}{|c|c|c|}
\hline $\begin{array}{l}\text { REPORT DOCUMENTATION } \\
\text { PAGE }\end{array}$ & \begin{tabular}{|l|l|}
1. REPORT NO. & 2. \\
\end{tabular} & 3. Recipient's Accession No. \\
\hline \multirow{2}{*}{\multicolumn{2}{|c|}{$\begin{array}{l}\text { 4. Title and subtitle HYDROLOGIC CHARACTERISTICS AND POSSIBLE EFFECTS OF } \\
\text { SURFACE MINING IN THE NORTHWESTERN PART OF WEST BRANCH ANTELOPE } \\
\text { CREEK BASIN, MERCER COUNTY, NORTH DAKOTA }\end{array}$}} & $\begin{array}{l}\text { 5. Report Date } \\
\text { December } 1981\end{array}$ \\
\hline & & 6. \\
\hline \multicolumn{2}{|c|}{ M. Author(s) Crawley and Douglas G. Emerson } & $\begin{array}{l}\text { 8. Performing Organization Rept. No. } \\
\text { WRI } 81-79\end{array}$ \\
\hline \multicolumn{2}{|c|}{$\begin{array}{l}\text { 9. Performing Organization Name and Address } \\
\text { U. S. Geological Survey } \\
821 \text { East Interstate Avenue } \\
\text { Bismarck, North Dakota } 58501\end{array}$} & $\begin{array}{l}\text { 10. Project/Task/Work Unit No. } \\
\text { 11. Contract(C) or Grant(G) No. } \\
\text { (C) } \\
\text { (G) }\end{array}$ \\
\hline \multirow{2}{*}{\multicolumn{2}{|c|}{$\begin{array}{l}\text { 12. Sponsoring Organization Name and Address } \\
\text { U. S. Geological Survey } \\
821 \text { East Interstate Avenue } \\
\text { Bismarck, North Dakota } 58501\end{array}$}} & $\begin{array}{l}\text { 13. Type of Report \& Period Covered } \\
\text { Final }\end{array}$ \\
\hline & & 14. \\
\hline
\end{tabular}

15. Supplementary Notes

Prepared in cooperation with the U.S. Bureau of Land Management

16. Abstract (Limit: 200 words) Lignite beds and abundant discontinuous sandstone beds of the Paleocene Sentinel Butte Member of the Fort Union Formation and sand and gravel beds in the Quaternary glaciofluvial deposits (Antelope Creek aquifer) are the most important aquifers in the West Branch Antelope Creek basin. In the Beulah-Zap 1ignite, ground water moves from highland area in the west toward the Antelope Creek aquifer. Water levels in the basal Sentinel Butte sandstone appear to be controlled by the level of Lake Sakakawea. In the glaciofluvial deposits of the Antelope Creek aquifer water moves from a ground-water divide northwestward to Lake Sakakawea and southeastward toward the Knife River.

Large water-level declines in wells completed in the lignite and shallower aquifers could be expected with mining. The effects probably would be 1 imited to within 1 to 2 miles of an active mine. Surface-runoff duration could be altered by increased infiltration and retention in the reclaimed area and possible temporal extension of base flow could occur.

Shallow ground water beneath mine sites would be expected to increase in dissolved solids and locally to contain large sodium and sulfate concentrations. In some locations movement of poor quality water toward Antelope Creek aquifer would be expected.

17. Document Analysis a. Descriptors

*Aquifers, *Ground water, *Runoff, *Surface drainage, Water chemistry, Mine drainage, Geochemistry.

b. Identifiers/Open-Ended Terms

Surface mining, Mercer County, North Dakota, Fort Union coal region

c. COSATI Field/Group

18. Availability Statement

No restriction on distribution

\begin{tabular}{l}
$\begin{array}{l}\text { 19. Security Class (This Report) } \\
\text { Unclass ified } \\
\text { 20. Security Class (This Page) } \\
\text { Unclassified }\end{array}$ \\
\hline
\end{tabular}

21. No. of Pages 73

22. Price


HYDROLOGIC CHARACTERISTICS AND POSSIBLE EFFECTS OF SURFACE MINING IN THE NORTHWESTERN PART OF WEST BRANCH ANTELOPE

CREEK BASIN, MERCER COUNTY, NORTH DAKOTA

By Mark E. Crawley and Douglas G. Emerson

U.S. GEOLOGICAL SURVEY

Water-Resources Investigations 81-79

Prepared in cooperation with the

U.S. BUREAU OF LAND MANAGEMENT

Bismarck, North Dakota

December 1981 


\section{UNITED STATES DEPARTMENT OF THE INTERIOR \\ JAMES G. WATT, Secretary \\ GEOLOGICAL SURVEY \\ Dallas L. Peck, Director}

For additional information write to:

District Chief,

U.S. Geological Survey

821 Interstate Avenue

Bismarck, ND 58501 
G1 os sary-

Abstract-1..

Introduction

Purpose and objectives-

Location-numbering system-...

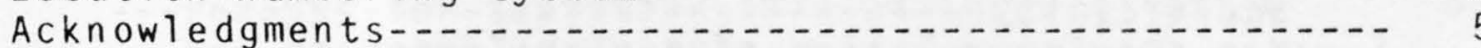

Future development plans in the study area...... 5

Previous investigations

Description of study area.

C1 imate-........... 7

Physiography

Ge 010 gy-

Fort Union Formation

Ludlow Member......................... 10

Cannonbal1 Member..................... 13

Tongue River Member..................... 13

Sentinel Butte Member................. 13

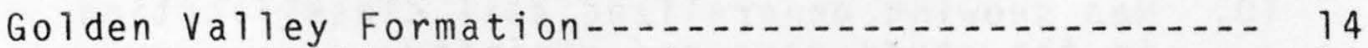

Glacial and alluvial deposits

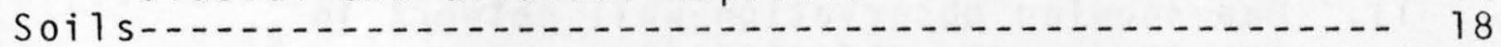

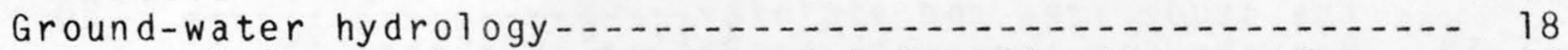

Basal Sentinel Butte and Beulah-Zap lignite aquifers--- 22

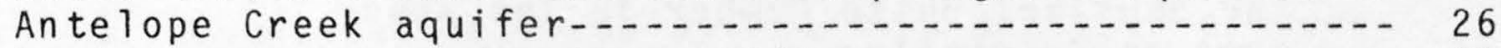

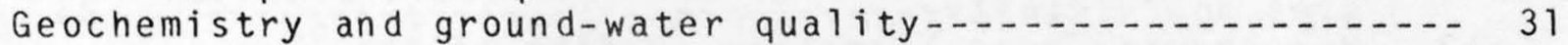

Mineralogy

Leaching potential-

Cation-exchange potential

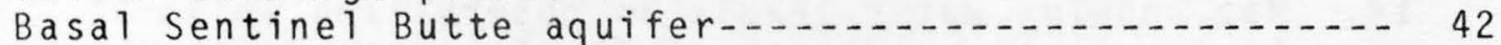

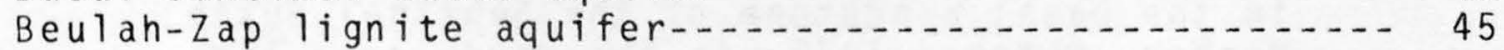

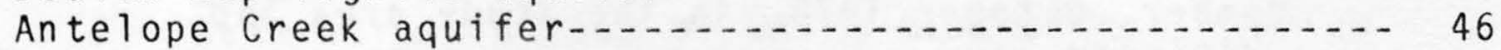

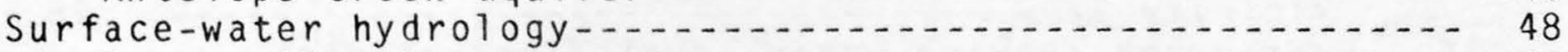

Data-collection network

Snowmelt and rainfall runoff_............... 50

Surface-water quality

Potential effects of future surface mining $\ldots \ldots \ldots . . . . . . . .63$

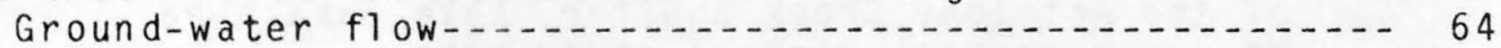

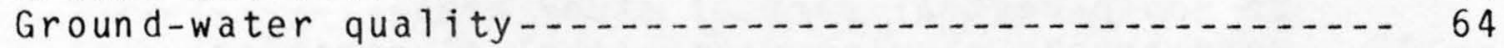

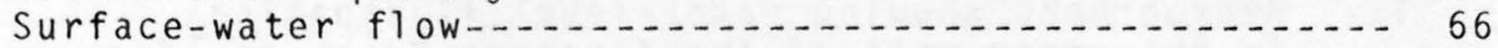

Surface-water quality

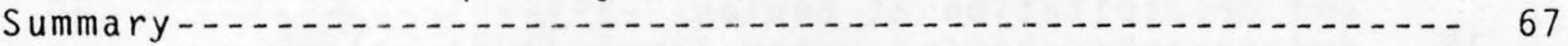

Selected references 
Figure 1. Map showing location study area-.......................

2. Diagram showing location-numbering

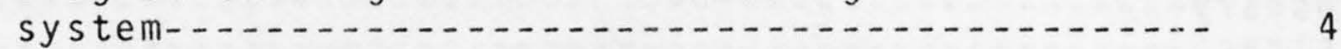

3. Map showing energy-development plans in the

study area and vicinity 6

4. Graphs showing climatic data for the study area and vicinity

5. Map showing relation of Beulah Trench to present drainage in the study area and vicinity- 9

6. Surficial geologic map of the study area and vicinity...... 12

7. Geohydrologic section across Beulah Trench glacial deposit (Antelope Creek aquifer)..... 15

8. Structure map of the top of the Beulah-Zap lignite bed in the study area and vicinity-.... 16

9. Geolohydrologic section through the Beulah Trench glacial deposit (Antelope Creek aquifer), Lake Sakakawea to southern boundary of study area-.--

10. Map showing generalized soil classification in the study area and vicinity.....

11. Map showing observation-well network in

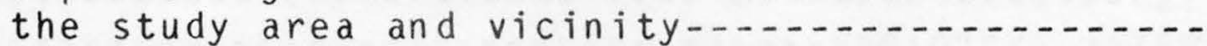

12. Map showing aggregate sandstone thickness of the Sentinel Butte Member in the study

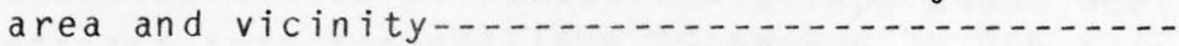

13. Map showing potentiometric surface of the Beulah-Zap lignite aquifer, July 1978, in the

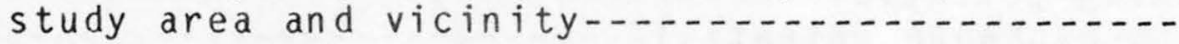

14. Map showing water levels in observation wells in the basal sandstone of the Sentinel Butte Member, October 1978, in the study area and

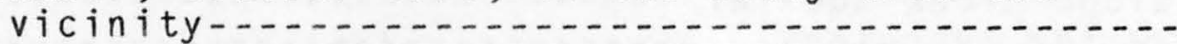

15. Hydrograph showing water-level fluctuations in the Beulah-Zap lignite aquifer and

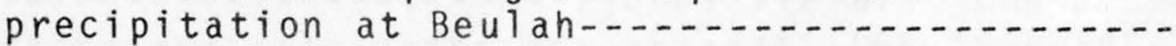

16. Map showing estimated transmissivities of part of the Antelope Creek aquifer, Lake Sakakawea to south-central part of study area...........

17. Hydrographs showing water-level fluctuations in the upper unit of the Antelope Creek aquifer

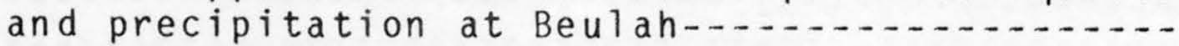

18. Hydrographs showing water-level fluctuations in the basal unit of the Antelope Creek aquifer

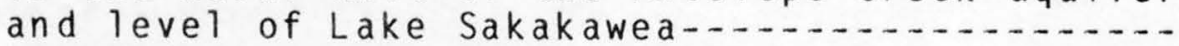

19. Map showing potentiometric surface of the basal unit of the Antelope Creek aquifer, September 1978, with stage of Lake Sakakawea at 1,845 feet, Lake Sakakawea to south-central part

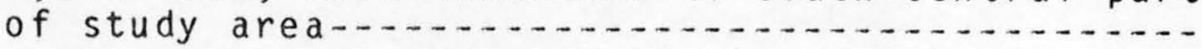


Figure 20. Map showing location of data-collection sites, excluding wells, in the study area and vicinity-

21. Graph showing rainfall frequency curves for the

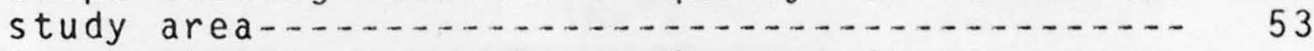

22. Graph showing comparison of precipitation records for september 1977 at three sites in

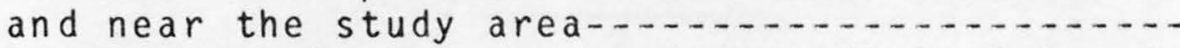

23. Hydrograph showing precipitation at Beulah and discharge at site M0.0....

24. Graph showing relationships of major ions in streamflow at sites Ml0.4, M5.8, and M0.0.....

25. Graph showing concentrations of dissolved constituents in streamflow at sites Ml0.4,

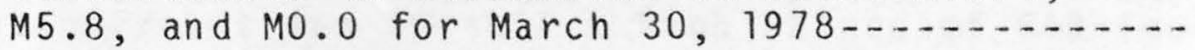

\section{TABLES}

Table 1. Generalized stratigraphy of rocks in the study area-1

2. Selected data for 27 wells in the study area and vicinity and water level of Lake Sakakawea-.....

3. Quantitative X-ray diffraction analyses of core material from two locations in the study area-.-

4. Composition of leachate from samples of core

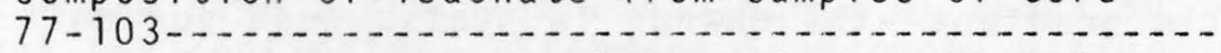

5. Exchangeable cation analyses of core 77-103.....

6. Chemical analyses of selected ground-water

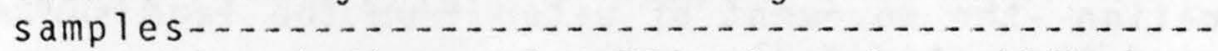

7. Saturation indices of WATEQ mineral equilibrium and solubility calculations for selected ground-

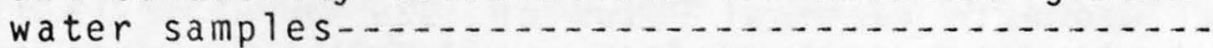

8. Monthly, annual, and average precipitation

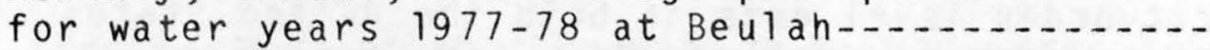

9. Flood discharges at selected recurrence probabilities and maximum recorded discharge for water years 1977-78 at sites M0.0, M5.8, and M10.4 0.4

10. Chemical analyses of surface-water

Sediment-sample data for sites Ml0.4, M5.8, and

11. Sediment-sample data for sites M10.4, M5.8, and 
Aquifer--a formation, group of formations, or part of a formation that contains sufficient saturated permeable material to yield significant amounts of water to wells and springs.

Bedrock--consolidated or semiconsolidated rock that underlies soil or other unconsolidated surficial material.

Gage height--the height of a water surface above an established datum. Stage commonly is interchangeable with the term "gage height."

Glaciofluvial--pertaining to streams flowing from glaciers or to the sediments deposited by such streams.

Ground water--water in the zone of saturation.

Head, static--the height above a standard datum of the surface of a column of water (or other liquid) that can be supported by the static pressure at a given point.

Hydraulic conductivity--the capacity of a rock to transmit water--usually described as the rate of flow in cubic feet per day through 1 square foot of the aquifer under unit hydraulic gradient, at existing kinematic viscosity.

Hydraulic gradient--the change in static head per unit of distance in a given direction.

Infiltration--the movement of water from the land surface toward the water table.

National Geodetic Vertical Datum of 1929 (NGVD of 1929)--A geodetic datum derived from a general adjustment of the first-order level nets of both the United States and Canada, formerly called "Mean Sea Level."

Porosity--a property of rock or soil containing interstices or voids, expressed as the ratio of the volume of its interstices to its total volume.

Potentiometric surface--the surface that represents the static head. It may be defined as the level to which water will rise in tightly cased wells. A water table is a potentiometric surface.

Recharge--the addition of water to the zone of saturation.

Second-order stream--a method of numbering streams as part of a drainage basin network. The smallest, unbranched tributary 
is called first order, the stream receiving the tributary is called second order.

Sodium-adsorption ratio--the sodium-adsorption ratio (SAR) of water is defined as:

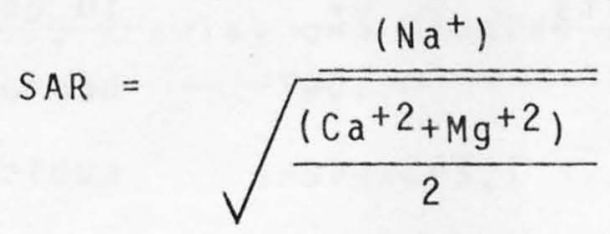

where ion concentrations are expressed in milliequivalents per liter. Experiments cited by the U.S. Salinity Laboratory Staff (1954) show that SAR predicts reasonably well the degree to which irrigation water tends to enter into cation reactions in soil. High values of SAR imply a hazard of sodium replacing adsorbed calcium and magnesium. This replacement is damaging to soil structure.

Specific capacity--The rate of discharge of water from a well divided by the drawdown of the water level within the well.

Specific conductance--electrical conductance is the ability of a solution to conduct an electrical current. The electrical conductivity of water is related to the concentration of ions in the water. Distilled water normally will have a specific conductance of about 1.0 micromhos per centimeter, whereas sea water may have a specific conductance of about 50,000 micromhos per centimeter. Standard laboratory measurements report the specific conductance of water in micromhos per centimeter at $25^{\circ}$ Celsius.

Storage coefficient--the volume of water an aquifer releases or takes into storage per unit surface area of the aquifer per unit change in static head.

Third-order stream--the stream receiving a second-order tributary.

Transmissivity--the rate at which water of the prevailing kinematic viscosity is transmitted through a unit width of the aquifer under a unit hydraulic gradient. It is equal to an integration of the hydraulic conductivities across the saturated part of the aquifer perpendicular to the flow paths.

Zone, saturated--that part of the water-bearing material in which all voids, large and small, are filled with water under pressure of 1 atmosphere or greater. 
The following factors may be used to convert the inch-pound units published herein to the International system (SI) of metric units.

\begin{tabular}{|c|c|c|}
\hline Multiply inch-pound units & By & To obtain SI units \\
\hline Acre & 0.4047 & hectare \\
\hline Acre-foot & 1,233 & cubic meter \\
\hline & 0.001233 & cubic hectometer \\
\hline $\begin{array}{l}\text { Acre-foot per square } \\
\left.\text { mile (acre-ft/mi } \mathrm{m}^{2}\right)\end{array}$ & 476.1 & $\begin{array}{l}\text { Cubic meter per square } \\
\text { kilometer }\end{array}$ \\
\hline $\begin{array}{l}\text { Cubic foot per second } \\
\left(\mathrm{ft}^{3} / \mathrm{s}\right)\end{array}$ & 0.02832 & cubic meter per second \\
\hline Foot & 0.3048 & meter \\
\hline Foot per day $(\mathrm{ft} / \mathrm{d})$ & 0.3048 & meter per day \\
\hline Foot per foot $(\mathrm{ft} / \mathrm{ft})$ & 0.3048 & meter per meter \\
\hline Foot per mile $(\mathrm{ft} / \mathrm{mi})$ & 0.18943 & meter per kilometer \\
\hline $\begin{array}{l}\text { Foot squared per day } \\
\qquad\left(f t^{2} / d\right)\end{array}$ & 0.9029 & meter squared per day \\
\hline $\begin{array}{l}\text { Gallon per minute } \\
(\mathrm{gal} / \mathrm{min})\end{array}$ & 0.6309 & liter per second \\
\hline Inch & 25.4 & millimeter \\
\hline Mile & 1.609 & kilometer \\
\hline Square mile $\left(\mathrm{mi}^{2}\right)$ & 2.590 & square kilometer \\
\hline
\end{tabular}




\section{HYDROLOGIC CHARACTERISTICS AND POSSIBLE EFFECTS \\ OF SURFACE MINING IN THE NORTHWESTERN PART OF \\ WEST BRANCH ANTELOPE CREEK BASIN, MERCER COUNTY, NORTH DAKOTA}

\section{By Mark E. Crawley and Douglas G. Emerson}

\section{ABSTRACT}

The Beulah-zap lignite bed in the sentinel Butte Member of the Fort Union Formation (Paleocene age) occurs at depths of 0 to 270 feet in the study area and vicinity. Strip mining, to supply a coal-fired electric generating plant and possibly a coal gasification plant, will commence in the area in the near future.

Abundant discontinuous sandstone beds and lignite beds of the Sentinel Butte Member and sand and gravel beds in the Quaternary glaciofluvial deposits are the most important aquifers for domestic and livestock water supplies. Water levels in the basal Sentinel Butte aquifer appear to be controlled by the level of Lake Sakakawea. In the Beulah-zap lignite, water moves from the highland area in the west toward the Quaternary deposits (Antelope Creek aquifer). In the Antelope Creek aquifer water moves from a ground-water divide northwestward to Lake Sakakawea and southeastward toward the Knife River.

Water in the basal sentinel Butte aquifer generally is a sodium bicarbonate type. Water in the Beulah-zap lignite is a calcium-magnesium sulfate or sodium bicarbonate type. Water from the Antelope Creek aquifer ranges from a calcium-magnesium bicarbonate to a sodium bicarbonate type.

The surface drainage in the study area generally is well developed. The streams are ephemeral and most of the flow occurs during spring snowmelt. The chemical quality of snowmelt runoff generally does not vary significantly from rainfall runoff. Surface water ranges from calcium-magnesium bicarbonate type to calcium-magnesium bicarbonate-sulfate type.

Large water-level declines in wells completed in the lignite and shallower aquifers could be expected with mining. The effects probably would be limited to within 1 to 2 miles of the active mine. Surface-runoff duration could be altered by increased infiltration and retention in the reclaimed area and possible temporal extension of base flow could occur. Shallow ground water beneath mine sites would be expected to increase in dissolved solids and locally to have large sodium and sulfate concentrations. In some locations, movement of the more mineralized water toward the Antelope Creek aquifer would be expected. 


\section{INTRODUCTION}

The study area $\left(28 \mathrm{mi}^{2}\right)$, which is in the Fort Union coal region, is the northwestern part of the West Branch Antelope Creek basin (fig. 1) in north-central Mercer County, North Dakota. The area was selected for study primarily because the location and availability of lignite deposits indicated that development of these deposits would occur in the near future and there could be significant hydrologic impact resulting from the development. The major economic activities in the general area are agriculture, lignite mining, and the production of energy by coal-fired generating complexes. Synthetic natural gas produced by coal gasification may become an economic product in the near future.

\section{Purpose and 0 bjectives}

Preliminary studies (Benson, 1952; Croft, 1970, 1973) indicated that proposed strip-mining activities in the west Branch Antelope Creek basin of North Dakota may result in changes in the streamflow, geochemical, and ground-water regimens. Some changes may be temporary, vet others may remain even after strip mining has ceased. Therefore, the purpose of this hydrologic investigation was to establish premining conditions as a standard to identify, measure, and evaluate any future changes.

The specific objectives of the study were to: (1) Determine the premining hydrologic and geochemical conditions in the 28 $\mathrm{mi}^{2}$ area; (2) provide a premining data base from which to measure the magnitude of change in the hydrologic system due to coal mining; and (3) determine the probable effects of mining on the water resources in the area.

\section{Location-Numbering System}

The location-numbering system used in this report is based on a system of land survey used by the U.S. Bureau of Land Management. The system is illustrated in figure 2. The first numeral denotes the township north of a base line, the second numeral denotes the range west of the Fifth Principal Meridian, and the third numeral denotes the section in which the well is located. The letters A, B, C, and D designate, respectively, the northeast, northwest, southwest, and southeast quarter section, quarter-quarter section, and quarter-quarter-quarter section (10-acre tract). For example, well 145-088-15ADC is in the 


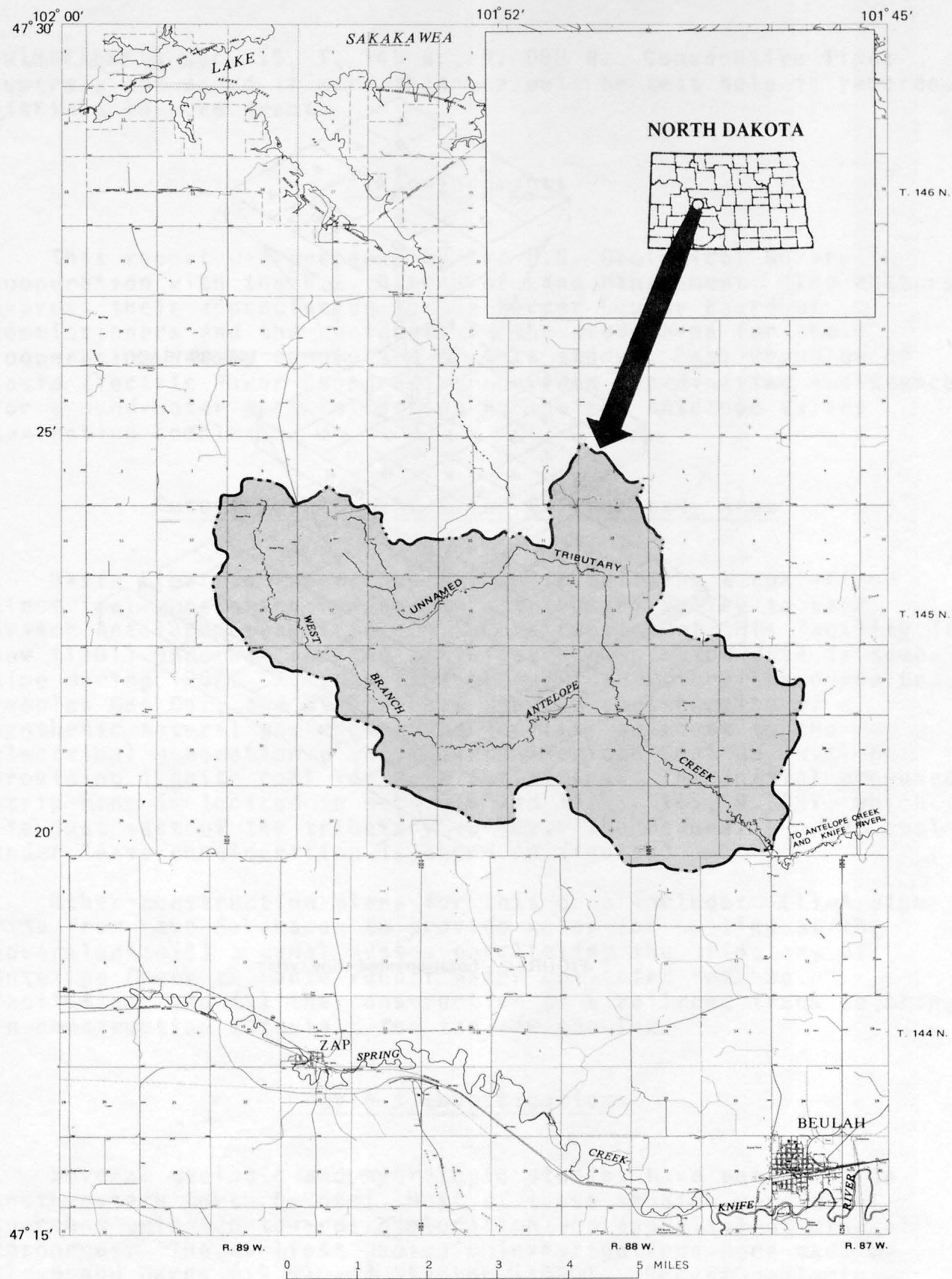

FIGURE 1.-Location of study area. 


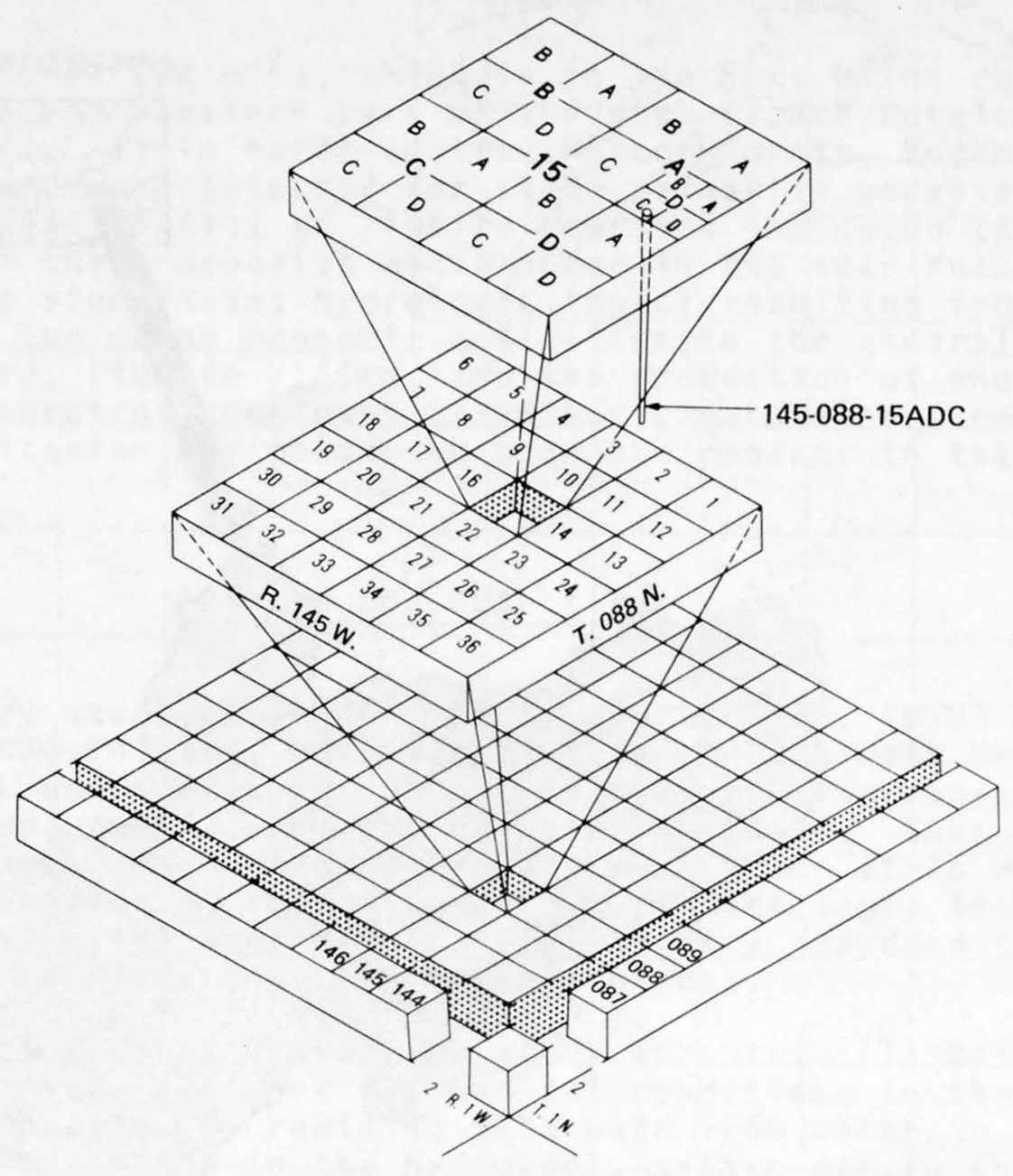

FIGURE 2.-Location-numbering system. 
SW $1 / 4$ SE $1 / 4$ NE1/4 sec. 15, T. 145 N., R. 088 W. Consecutive final numerals are added if more than one well or test hole is recorded within a 10-acre tract.

\section{Acknowledgments}

This report was prepared by the U.S. Geological Survey in cooperation with the U.S. Bureau of Land Management. The authors express their appreciation to the Mercer County Board of Commissioners and the residents in the study area for their cooperation in the completion of this study. Paul Reynolds of Basin Electric Power Cooperative provided coordinating assistance for ground-water data collection at the new Antelope Valley generating complex.

\section{Future Development Plans in the Study Area}

Basin Electric Power Cooperative is building a coal-fired electrical generating complex in a tributary valley to West Branch Antelope Creek (fig. 3). Construction of this facility is now (1981) underway and the anticipated completion date is sometime during 1982. A consortium of American Natural Resource Co., Peoples Gas Co., and others have started construction of a synthetic natural gas production facility adjacent to the electrical generation plant. North American Coal Co. will be providing lignite coal for both facilities. The initial proposed strip mine is located in secs. 18 and 19, T. 145, R. 087, which lie just east of the tributary valley. The Federally-owned coal under lease consideration is shown on figure 3 .

Other construction plans for this area include: (1) A pipeline from Lake Sakakawea to provide water for cooling at the powerplant; (2) a canal system paralleling the tributary of Antelope Creek to route runoff water collected near both facilities; and (3) the construction of a railroad track to bring in construction materials for the new complex.

\section{Previous Investigations}

Several geologic and hydrologic studies have been made in southwestern North Dakota. Most of these studies were areal searches oriented towards exploration and appraisal of mineral resources. The earliest geologic investigations were made by Lloyd and Hares (1915) and Stanton (1920). Recent geologic investigations have been made by Benson (1952), Johnson and Kunkel (1959), Denson and Gill (1965), Pipiringos, Chisholm, and 


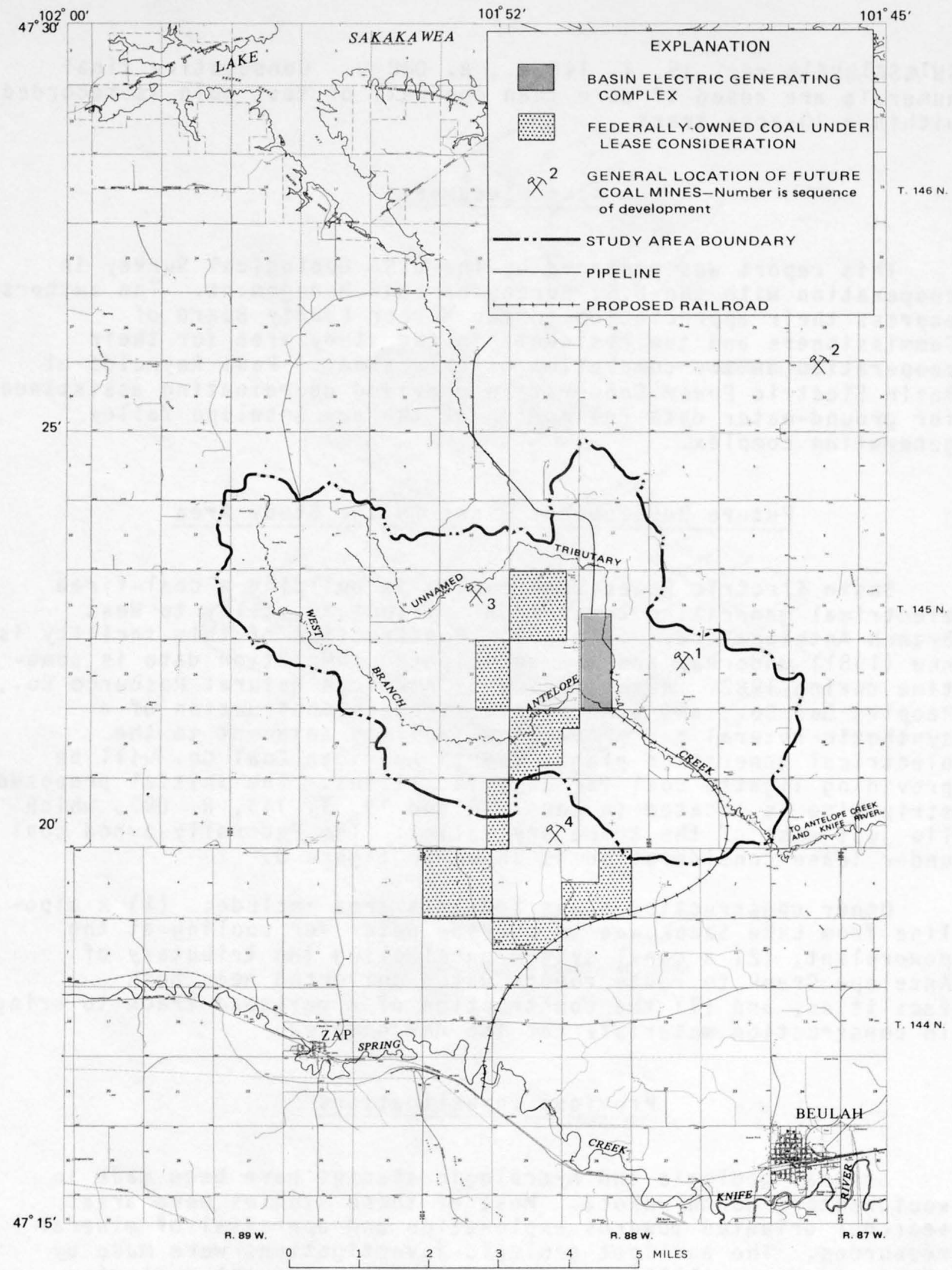

FIGURE 3.-Energy-development plans in the study area and vicinity. 
Kepferle (1965), and Kume and Hansen (1965). Bradley and Jensen (1962) made a ground-water study near Beulah and reported the results of their test drilling. Croft (1973) made a ground-water study of Mercer and 01 iver Counties and Carlson (1973) reported on the geology of those two counties. Croft's and Carlson's reports provided much of the background information for this investigation.

\section{DESCRIPTION OF STUDY AREA}

\section{Climate}

The climate of the west Branch Antelope Creek study area is cool and semi-arid. The mean annual temperature at Beulah for 1959-78 as recorded by the U.S. Environmental Data Service (1960-79) was $41.0^{\circ} \mathrm{F}$ (fig. 4A). January, with a mean temperature of $7^{\circ} \mathrm{F}$, usually is the coldest month. The record low temperature at Beulah was $-42^{\circ} \mathrm{F}$ during February 1959 and during January 1968. July, with a mean temperature of about $70^{\circ} \mathrm{F}$, is the warmest

month of the year. Record high temperature was $108^{\circ} \mathrm{F}$ during July 1960. The average growing season is 120 days.

The mean annual precipitation recorded at Beulah for 1959-78 was 16.5 inches (fig. 4B). The spring and summer (April-September) usually have the greatest amount of precipitation, while the fall and winter have the least (fig. 4C).

\section{Physiography}

Part of a topographic feature known as the Beulah Trench lies within the study area (Benson, 1952). The Beulah Trench (fig. $5)$ is a glacial river valley extending from Lake Sakakawea southward to about 4 miles north of Beulah where it splits into two branches. One branch trends southwest toward Spring Creek and the other branch trends east-southeast toward Antelope Creek and the Knife River.

The uplands in the western part of the study area have a maximum altitude of about 2,300 feet. The lowest altitude, 1,860 feet, occurs at the downstream point of West Branch Antelope Creek where it leaves the study area. Maximum relief is 440 feet. Much of the uplands are covered with thin glacial drift, however, isolated ridges and buttes are capped by sandstone, claystone, or "scoria"--a local term for fused or baked clay, shale, or sandstone that resulted from the burning of adjacent lignite beds. The valley floor is covered with alluvium. 

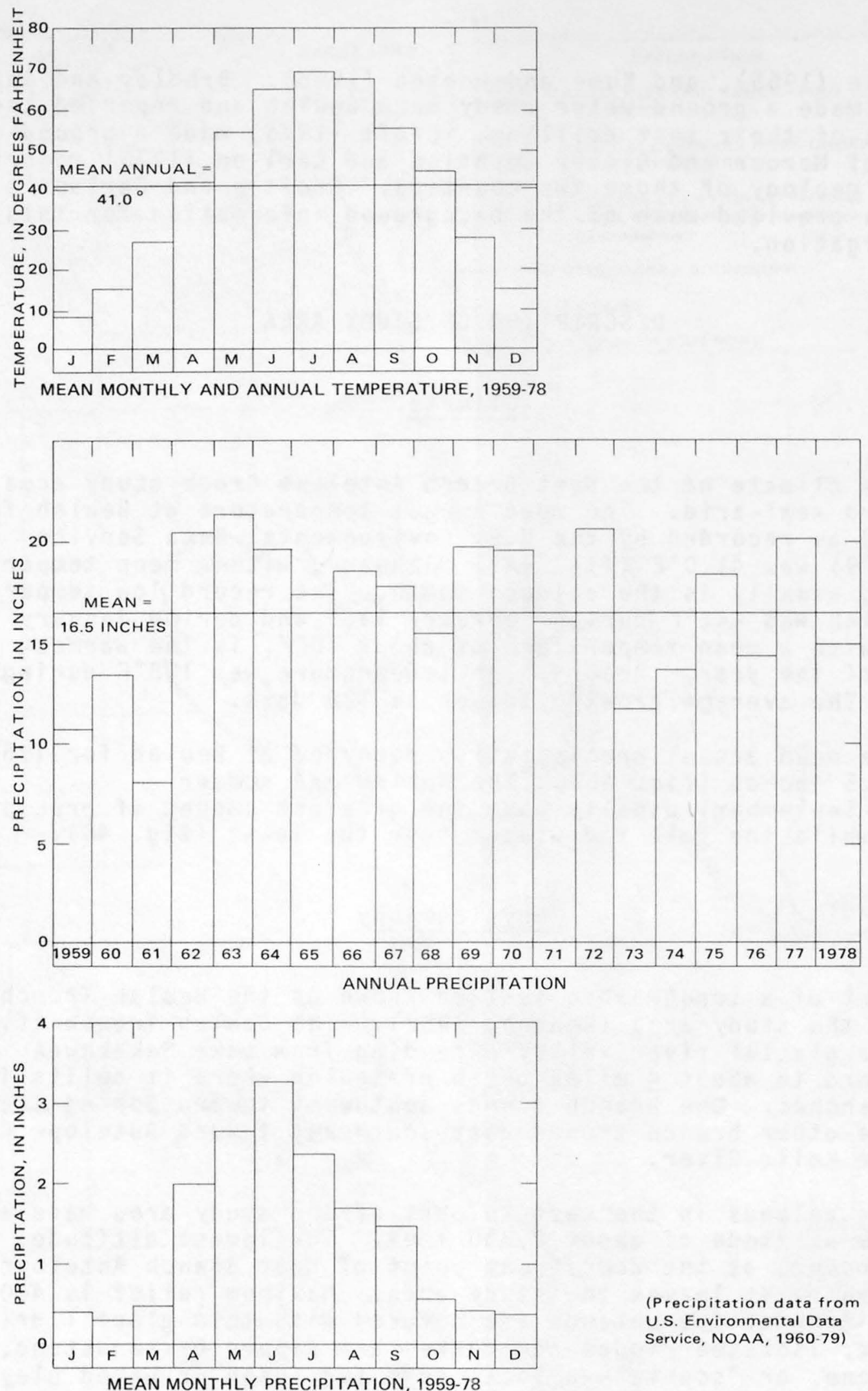

(Precipitation data from U.S. Environmental Data Service, NOAA, 1960-79)

FIGURE 4.-Climatic data for the study area and vicinity, recorded at Beulah, North Dakota. 


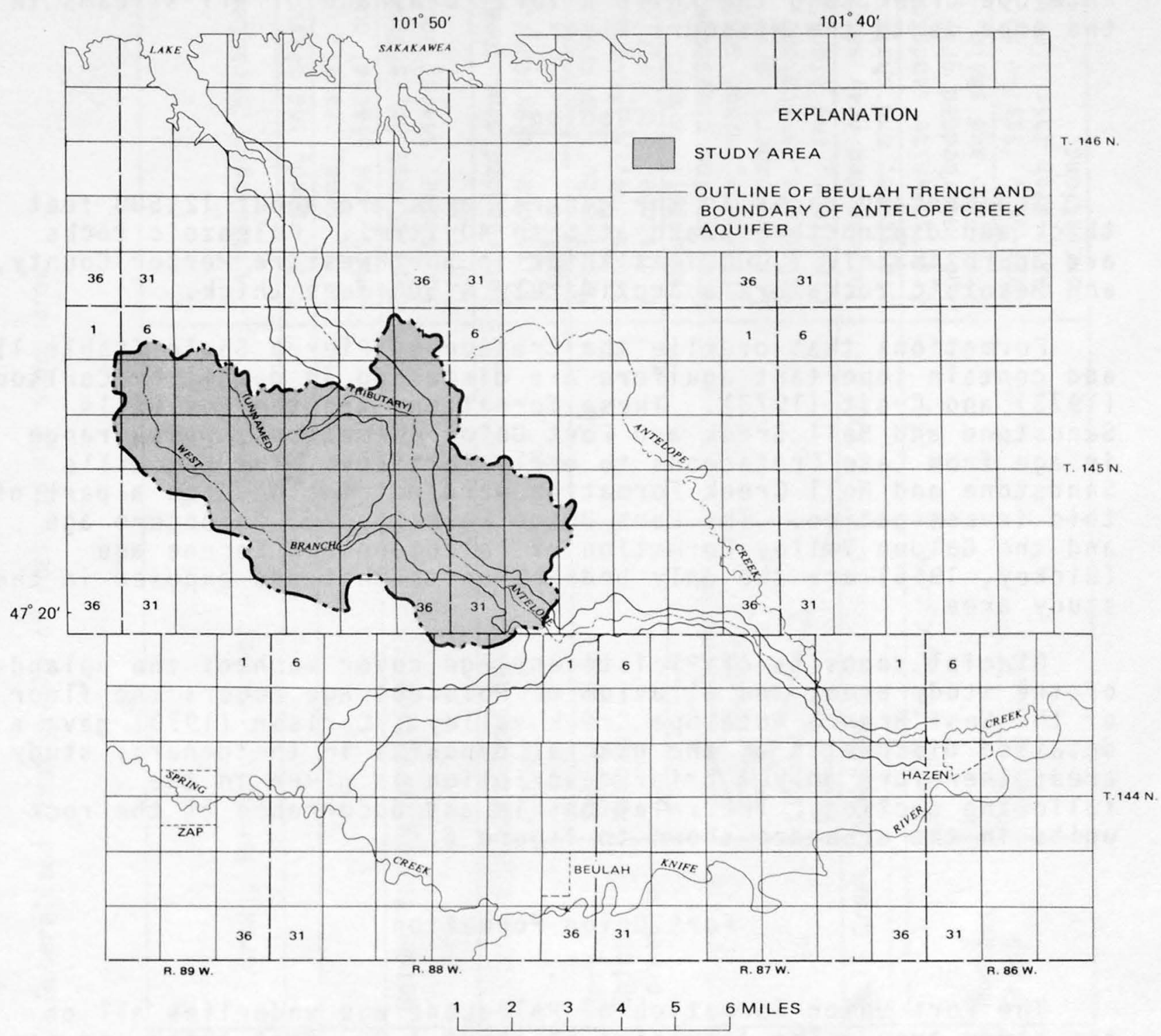

FIGURE 5.-Relation of Beulah Trench to present drainage in the study area and vicinity. 
Principal streams in the general area are Spring Creek, Antelope Creek, and the Knife River. Drainage of all streams in the area is to the Missouri River.

\section{$\underline{\text { Geology }}$}

Sedimentary rocks in the general area are about 12,500 feet thick and dip northwestward at 5 to $40 \mathrm{ft} / \mathrm{mi}$. Paleozoic rocks are approximately 7,000 feet thick in northwestern Mercer County, and Mesozoic rocks are approximately 4,500 feet thick.

Formations that overlie the Cretaceous Pierre Shale (table 1) and contain important aquifers are discussed in detail by Carlson (1973) and Croft (1973). These formations are the Fox Hills Sandstone and Hell Creek and Fort Union Formations, which range in age from Late Cretaceous to early Tertiary. The Fox Hills Sandstone and Hell Creek Formation were not included as a part of this investigation. The Fort Union Formation of Paleocene age and the Golden Valley Formation of Paleocene and Eocene age (Hickey, 1966) are the only bedrock units that are exposed in the study area.

Glacial deposits of Pleistocene age cover much of the uplands of the study area, and alluvium of Holocere age covers the floor of the West Branch Antelope Creek valley. Carlson (1973) gave a detailed discussion of the glacial deposits in the general study area; therefore only a brief description is given in the following section. The relationship and occurrence of the rock units in the area are shown in figure 6 .

\section{Fort Union Formation}

The Fort Union Formation of Paleocene age underlies all of the study area. The formation is about 1,200 feet thick and consists of interbedded claystone, siltstone, sandstone, and lignite. The formation has been divided into the Ludlow, Cannonball, Tongue River, and Sentinel Butte Members. The Sentinel Butte Member is the only one that is exposed in the study area (fig. 6).

\section{Ludlow Member}

The Ludlow Member is a continental deposit that consists of olive-gray sandstone, siltstone, brown lignitic shale and claystone, and lignite. The top of the Ludlow occurs at depths of from 950 to 1,150 feet (Carlson, 1973) and the member is about 
TABLE 1.--Generalized stratigraphy of rocks in the study area

\begin{tabular}{|c|c|c|c|c|c|c|}
\hline Era & System & Series & \multicolumn{2}{|c|}{ Group, formation, member } & $\begin{array}{l}\text { Approximate } \\
\text { thickness, } \\
\text { in feet }\end{array}$ & Lithologic characteristics \\
\hline \multirow{6}{*}{$\begin{array}{l}\frac{0}{0} \\
\text { O } \\
\text { O } \\
\text { d } \\
\end{array}$} & \multirow{2}{*}{ Quaternary } & Holocene & & & $0-30$ & Silt, sand, and clay. \\
\hline & & Pleistocene & & & $0-350$ & $\begin{array}{l}\text { Silt, sand, gravel, glacial } \\
\text { drift, and glacial outwash. }\end{array}$ \\
\hline & \multirow{4}{*}{ Tertiary } & Eocene & \multicolumn{2}{|c|}{ Golden Valley Formation } & $?$ & $\begin{array}{l}\text { Gray claystone, siltstone, } \\
\text { sandstone, shaie, and }\end{array}$ \\
\hline & & \multirow{3}{*}{ Paleocene } & \multirow{3}{*}{$\begin{array}{l}\text { Fort } \\
\text { Union } \\
\text { Formation }\end{array}$} & $\begin{array}{l}\text { Sentinel Butte } \\
\text { Member }\end{array}$ & $0-500$ & $\begin{array}{l}\text { Interbedded sandstone, } \\
\text { siltstone, claystone, and } \\
\text { lignite. }\end{array}$ \\
\hline & & & & $\begin{array}{l}\text { Tongue River } \\
\text { Member }\end{array}$ & 400 & $\begin{array}{l}\text { Massive buff to gray } \\
\text { sandstone, siltstone, } \\
\text { claystone, and lignite. }\end{array}$ \\
\hline & & & & $\overbrace{\substack{\text { Ludlow } \\
\text { Member }}}$ & 300 & $\begin{array}{l}\text { Cannonball Member: greenish- } \\
\text { gray marine claystone, } \\
\text { siltstone, minor sandstone. } \\
\text { Ludlow Member: gray } \\
\text { sandstone, siltstone, } \\
\text { claystone, and lignite. }\end{array}$ \\
\hline \multirow{3}{*}{$\begin{array}{l}0 \\
\text { O } \\
N \\
0 \\
心 \\
\sum\end{array}$} & \multirow{3}{*}{ Cretaceous } & \multirow{3}{*}{$\begin{array}{l}\text { Upper } \\
\text { Cretaceous }\end{array}$} & \multicolumn{2}{|c|}{ Hell Creek Formation } & 300 & $\begin{array}{l}\text { Interbedded gray sandstone, } \\
\text { claystone, and shale. }\end{array}$ \\
\hline & & & \multirow{2}{*}{$\begin{array}{l}\text { Montana } \\
\text { Group }\end{array}$} & Fox Hills Sandstone & 250 & $\begin{array}{l}\text { Grayish-white sandstone } \\
\text { and interbedded gray } \\
\text { siltstone and shale. }\end{array}$ \\
\hline & & & & Pierre Shale & 1,100 & $\begin{array}{l}\text { Dark-gray fissile marine } \\
\text { shale with thin limestone } \\
\text { concretions. }\end{array}$ \\
\hline
\end{tabular}




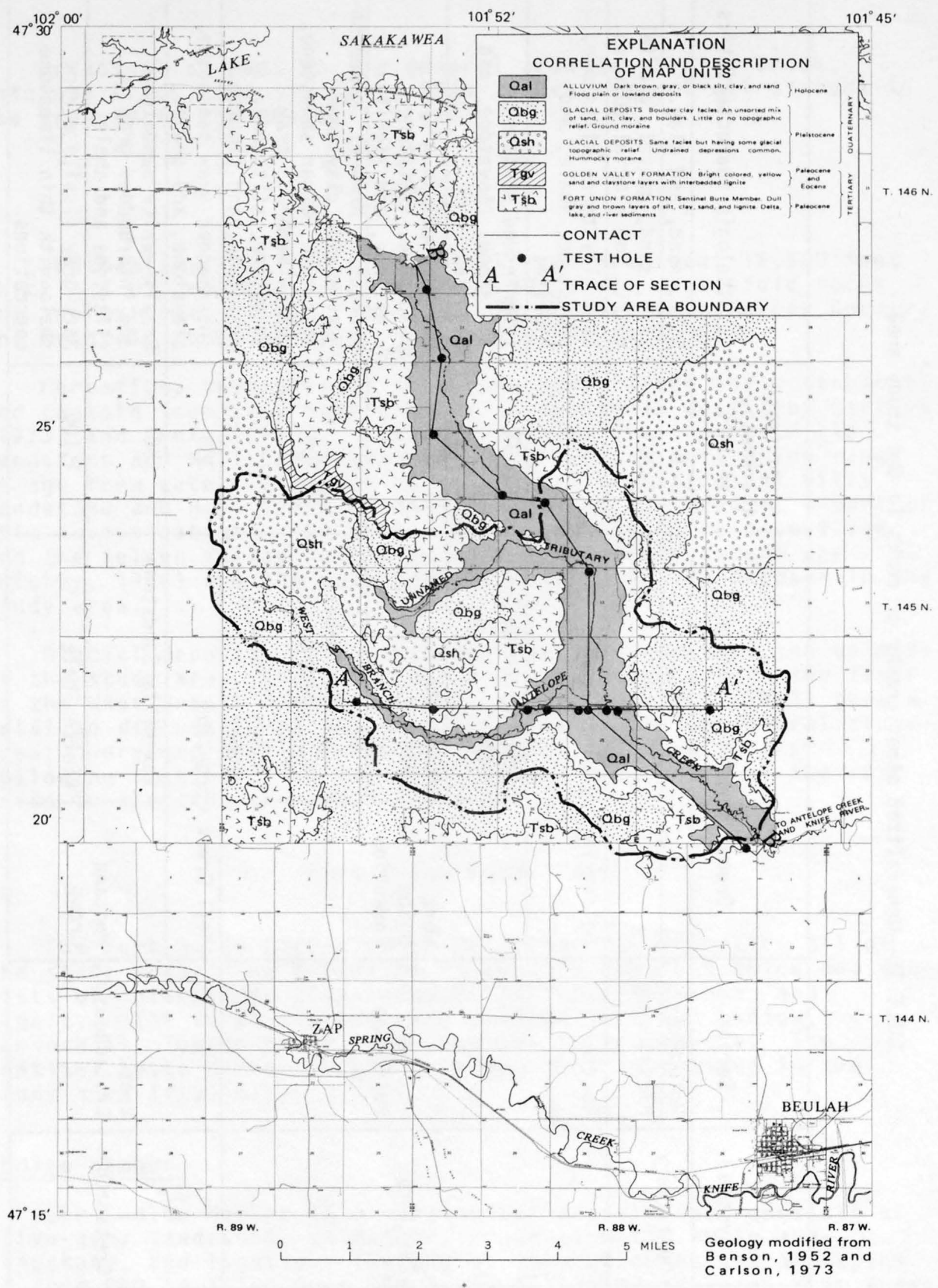

FIGURE 6.-Surficial geologic map of the study area and vicinity. 
80 feet thick in the study area. It generally dips northwestward at about 10 to $20 \mathrm{ft} / \mathrm{mi}$ toward the center of the Williston basin.

\section{Cannonball Member}

The Cannonball Member represents the youngest marine strata in the northern Great Plains. The Cannonball consists of interbedded olive to greenish-black siltstone and nearly impermeable claystone and shale and minor sandstone. This member occurs at depths of 750 to 960 feet in the study area (Carlson, 1973). It has a local thickness of 180 to 200 feet and dips northwestward at about 10 to $20 \mathrm{ft} / \mathrm{mi}$. The fine-grained sedimentary rocks of the Cannonball act as a confining bed to aquifer systems above and below the member.

\section{Tongue River Member}

The Tongue River Member consists of continental deposits. The Tongue River consists of interbedded light-olive-gray to greenish-gray claystone, siltstone, sandstone, and lignite that weather to light gray and light yellowish gray in outcrop exposures. Lignite beds are common in the Tongue River, but in the study area there are no mineable lignites in this member. Sandstone comprises about 10 percent of the Tongue River Member, while siltstone and claystone comprise about 70 to 80 percent, and lignite comprises about 10 percent. The Tongue River occurs at depths of 300 to 600 feet and is about 400 feet thick in the study area.

\section{Sentinel Butte Member}

The Sentinel Butte Member is a lignite-bearing, nonmarine unit of Paleocene age. It is very similar in lithology to the Tongue River; however, its outcrop is darker in color. The Sentinel Butte consists of interbedded sandstone, siltstone, claystone, limestone, and lignite. Sandstones comprise about 30 percent of the member, whereas siltstone and claystone comprise about 65 percent, and lignite only a few percent. There usually is a sandstone at the base of the member.

The Sentinel Butte Member is conformably underlain by the Tongue River Member. In most of the study area the Sentinel Butte Member has been extensively eroded and is overlain by glacial sediment; however, it is conformably overlain by the Paleocene and Eocene Golden Valley Formation in a small area. The Sentinel Butte crops out along the sides of the valleys (fig. 6 ) and locally caps ridges and buttes. It generally is 300 to 500 feet thick in the study area. In the western part of the study area the member occurs at a maximum altitude of 2,123 feet 
in wel1 145-088-16BBB, and has a thickness of about 500 feet. It has been eroded to an altitude of about 1,975 feet on the eastern side of the study area (fig. 7), where it is about 300 feet thick (we 11 145-087-29BBB).

The Sentinel Butte Member contains several lignite beds, including the Stanton, Spear, Insert, Beulah Zap, and Schoolhouse beds. The Beulah-Zap is the main lignite bed to be mined. It occurs at a depth of 0 to 270 feet in the study area and has an average thickness of 20 feet. A regional trend is not discernible on the structural-contour map (fig. 8) of the Beulah-Zap bed. There are minute folds and warps that are not reflected in the contours. These were apparently due to differential compaction during Pleistocene glaciation.

\section{Golden Valley Formation}

The Golden Valley Formation is Eocene in age and consists of claystone, siltstone, shale, minor carbonaceous beds, and some sandstone. The formation usually is very light gray and weathers to a bright yellowish and orange gray. The Golden Valley conformably overlies the Sentinel Butte and crops out in the study area in T. 145, R. 88, secs. 5, 6, and 9 (fig. 6). Thickness is variable, depending on the degree of erosion. The thickness of the Golden Valley in the study area was not determined because of 1 imited outcrop exposures.

\section{Glacial and Alluvial Deposits.}

Pleistocene glacial and Holocene alluvial deposits cover much of the surface of the study area (fig. 6). The glacial deposits in the uplands consist of from 0 to 60 feet of till, which is characterized by intermixed dark-brown clay, silt, sand, pebbles, and large boulders. The thickest deposits occur in the western part of the study area. The intermixed pebbles usually consist of scoria, limestone or dolomite, and igneous and metamorphic rock fragments. The landscape in the scudy area is littered with large boulders derived from melting and retreating glaciers.

Glacial deposits that occur in the Beulah Trench consist of glaciofluvial sand and gravel interbedded with silt and clay (fig. 9). Maximum recorded thickness in the study area is 350 feet in well 145-088-25BAB. Beulah Trench has incised all of the Sentinel Butte Member and the glacial deposits rest upon the Tongue River Member (fig. 7). Overlying much of the Beulah Trench glacial deposit is 10 to 30 feet of alluvium, which consists of dark silt and clay derived from the uplands adjacent to the valley. 


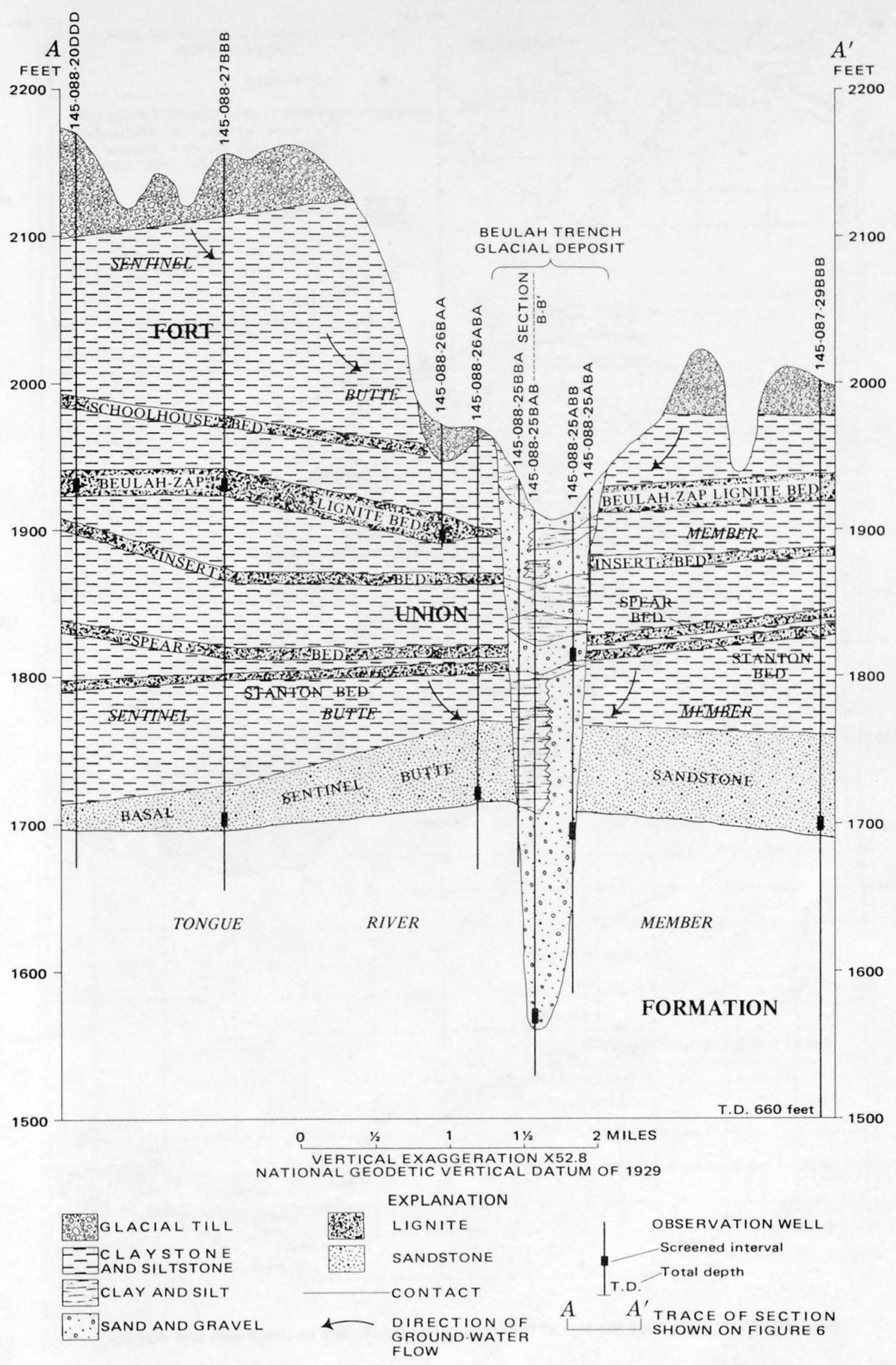

FIGURE 7 -Geohydrologic section across Beulah Trench glacial deposit (Antelope Creek aquifer). 


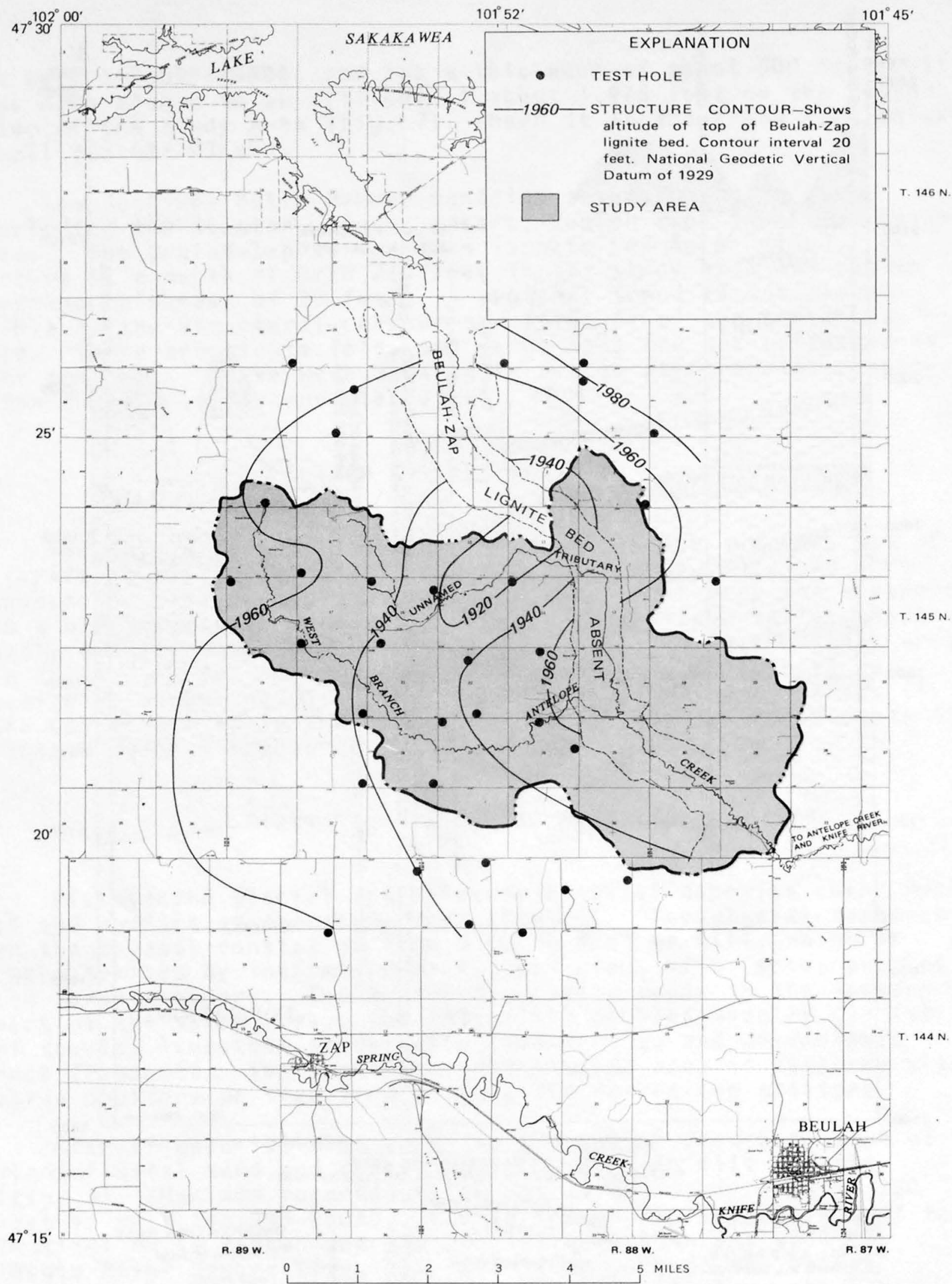

FIGURE 8.-Structure of the top of the Beulah-Zap lignite bed in study area and vicinity. 


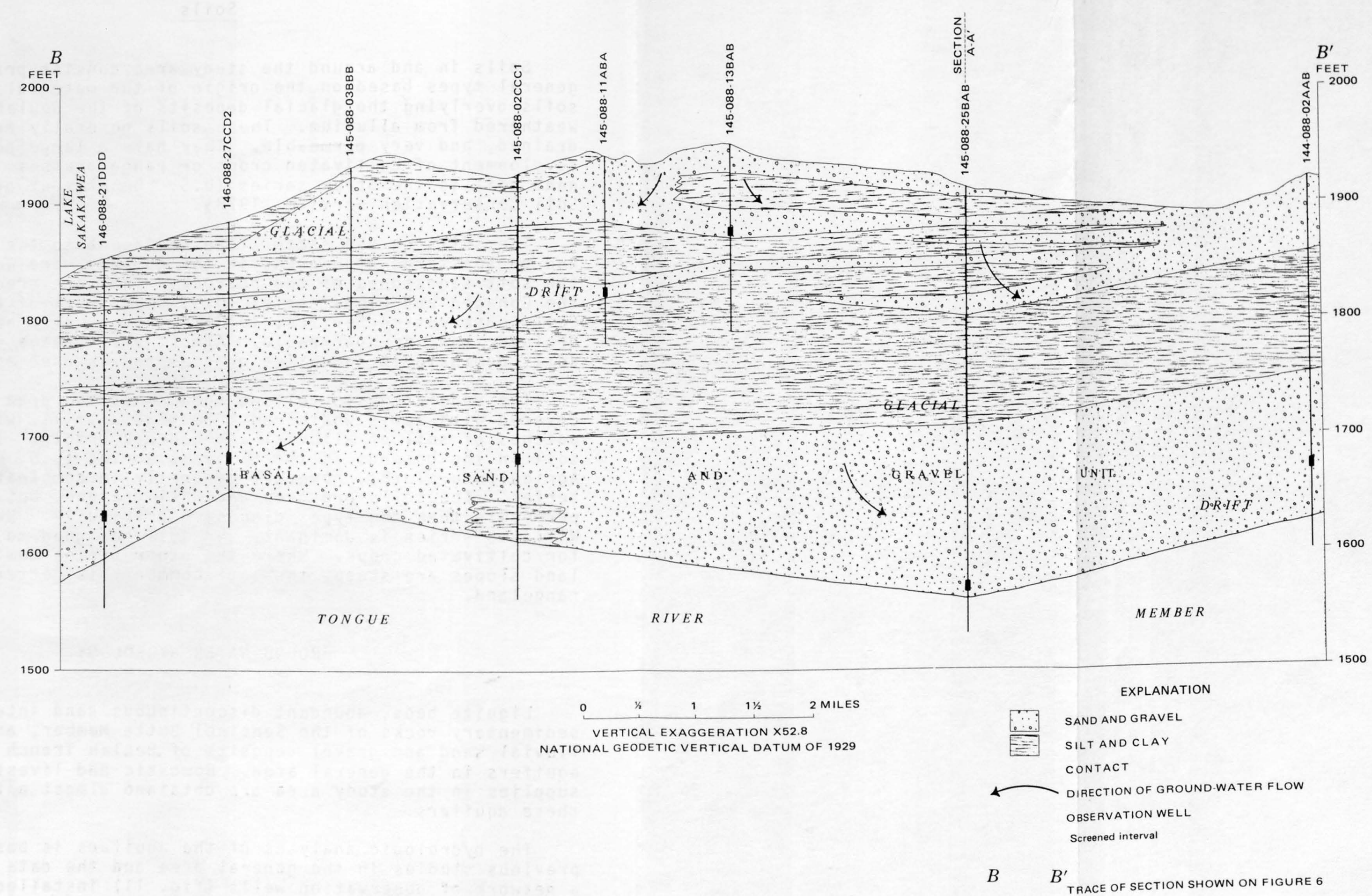

FIGURE 9.-Geohydrologic section through the Beulah Trench glacial deposit (Antelope Creek aquifer) Lake Sakakawea to southern boundary of study area. 
Soils in and around the study area consist primarily of three general types based on the origin of the material (fig. 10). The soils overlying the glacial deposits of the Beulah Trench were weathered from alluvium. These soils generally are deep, well drained, and very permeable. They have a large potential for development of cultivated crops or range grasses. The predominant soil is the Straw series (U.S. Department of Agriculture, Soil Conservation Service, 1978).

The soils on the steep slopes adjacent to the Beulah Trench and on scattered high areas in the uplands were weathered from the soft sandstones of the bedrock. They are predominantiy of the Cohagen and Cabba series (U.S. Department of Agriculture, Soil Conservation Service, 1978). They usually are shallow, well drained, and very permeable. Almost all acreage where these soils dominate is in native grasses and is used as rangeland.

The undulating to rolling uplands of the area generally are covered with soils weathered from glacial till, with scattered patches of soil of alluvial and bedrock origin. The predominant soil in the uplands is the Williams series (U.S. Department of Agriculture, 1978), however, generally in combination with other series. The soils are deep and well drained, but generally less permeable than the types discussed previously. Where the Williams series is dominant, the soil has good to fair potential for cultivated crops. Where the other series dominate or where land slopes are steep, the soil commonly is better suited to rangeland.

\section{GROUND-WATER HYDROLOGY}

Lignite beds, abundant discontinuous sand intervals in the sedimentary rocks of the Sentinel Butte Member, and the glaciofluvial sand and gravel deposits of Beulah Trench are important aquifers in the general area. Domestic and livestock water supplies in the study area are obtained almost entirely from these aquifers.

The hydrologic analyses of the aquifers is based primarily on previous studies in the general area and the data collected from a network of observation wells (fig. 11) installed in the study area. The location, water levels, and other related information for selected wells from the network are listed in table 2 . 


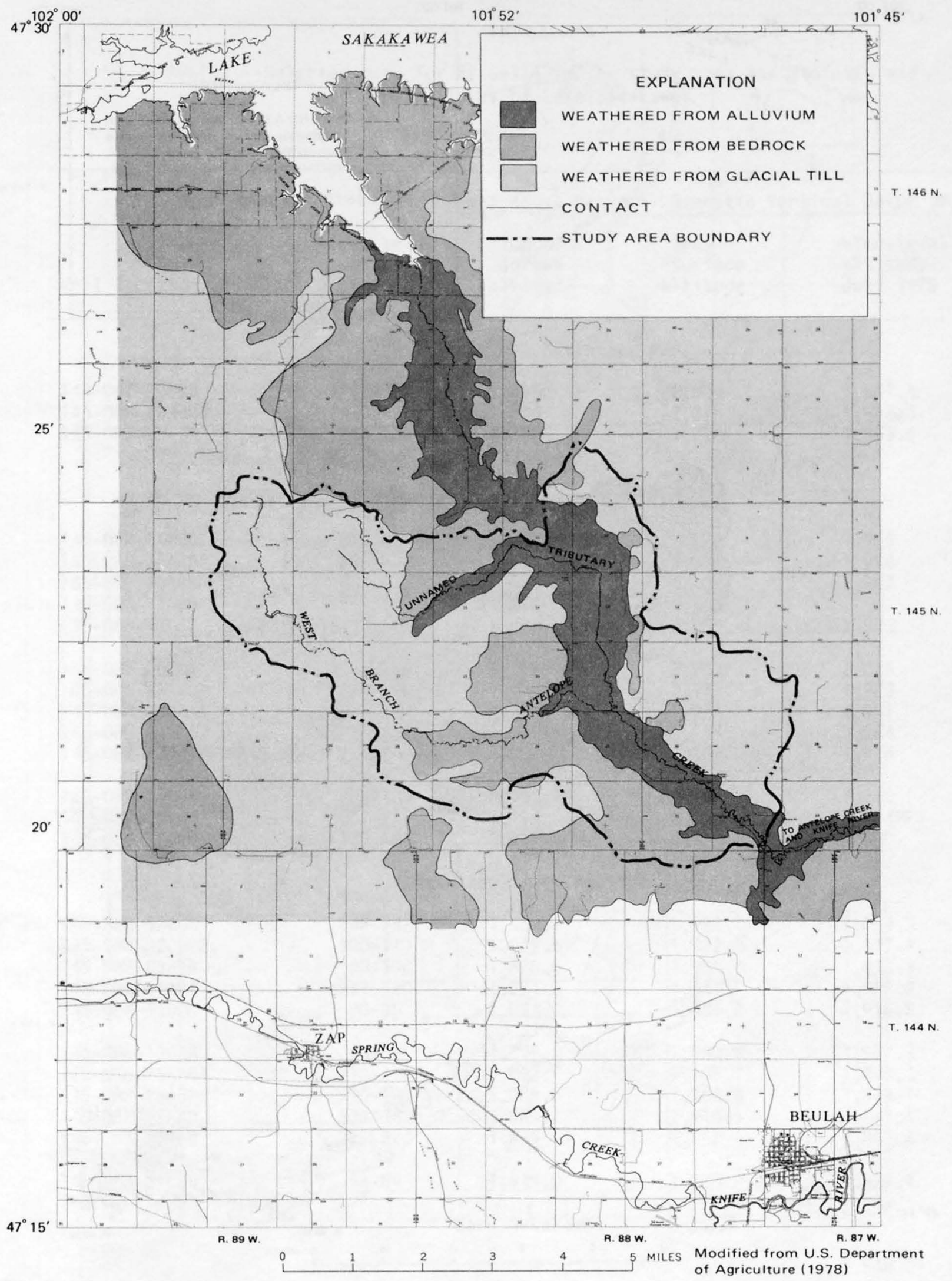

FIGURE 10.-Generalized soil classification in the study area and vicinity. 


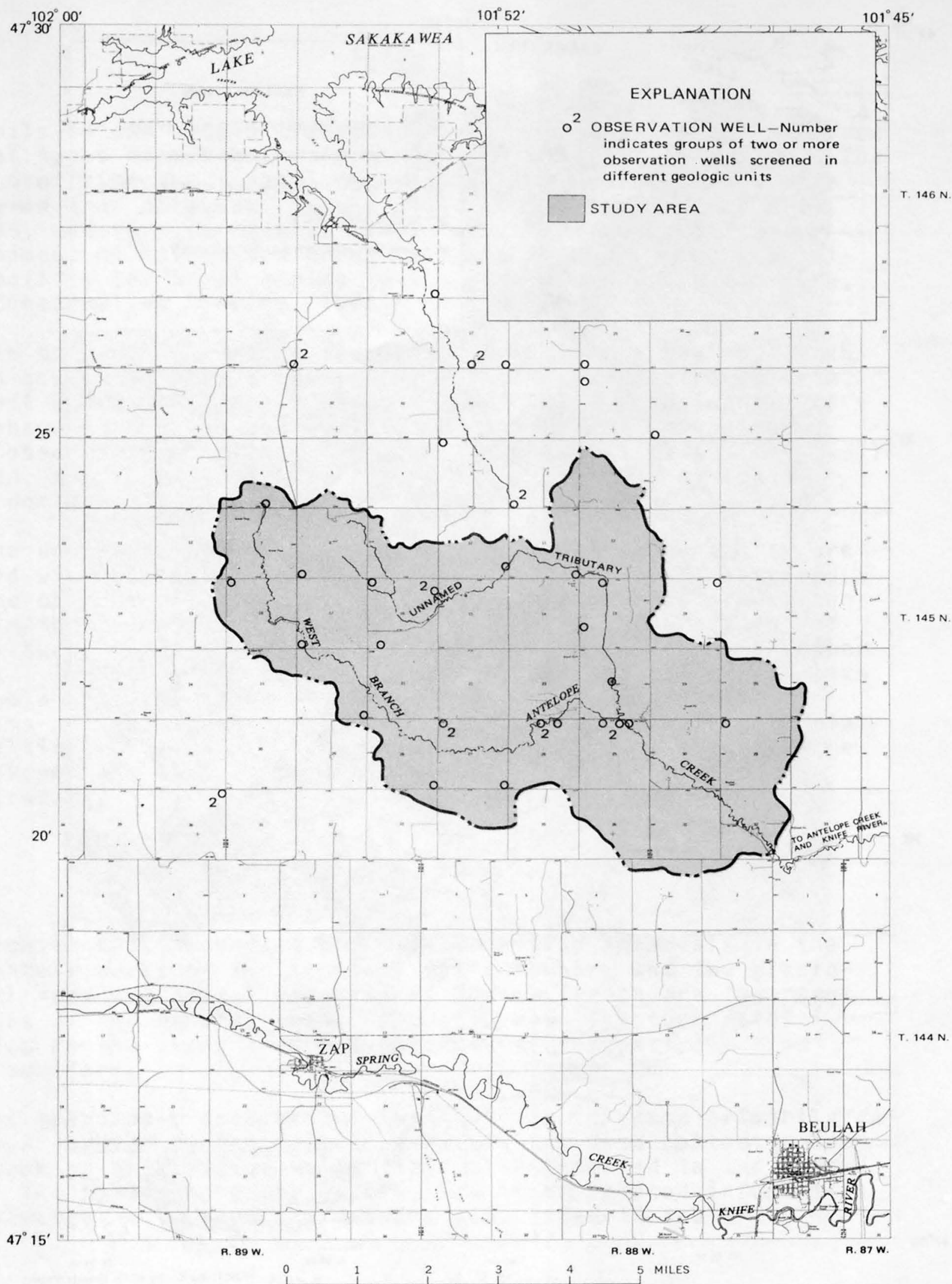

FIGURE 11.-Observation-well network in the study area and vicinity. 
TABLE 2.--Selected data for 27 wells in the study area and vicinity and water level of Lake Sakakawea

\begin{tabular}{ccccc}
\hline & $\begin{array}{c}\text { Screened } \\
\text { depth }\end{array}$ & Feet above National Geodetic Vertical Datum of 1929 \\
\cline { 3 - 5 } (feet below & Top of & Ground- & Water-level \\
ground & screen & surface & altitude \\
surface) & altitude & altitude & July 1978
\end{tabular}

145-087-29BBB

$145-088-16 A A D 1$

145-088-26ABA

$145-088-06 D C C$

145-088-16AAD2

$145-088-16 B B B$

$145-088-16 C C D$

$145-088-17 C C C$

$145-088-18 B B B$

145-088-20DDD

145-088-26BAA

$145-088-27 B B B 2$

$145-088-28 D D D$

145-088-290DD

145-089-36AAA1

146-088-30DDD 1

$145-088-02 \mathrm{CCC} 1$

145-088-02CCC2

145-088-03BBB

145-088-11 1 ABA

145-088-110DD

145-088-13BAR

$145-088-25 A B B 1$

$145-088-25 A B B 2$

$145-088-25 B A B$

$146-088-210 D D$

$146-088-27 C C D$
Basal Sentinel Butte aquifer

$\begin{array}{llll}293-305 & 1,699 & 2,004 & 1,847.4 \\ 420-426 & 1,644 & 2,070 & 1,847.3 \\ 258-264 & 1,706 & 1,970 & 1,853.6\end{array}$

Beulah-Zap lignite aquifer

$\begin{array}{cccr}317-323 & 1,947 & 2,270 & 1,976 \\ 168-174 & 1,908 & 2,082 & 1,976 \\ 239-245 & 1,947 & 2,192 & 1,967 \\ 258-269 & 1,919 & 2,188 & -- \\ 237-243 & 1,937 & 2,180 & 1,983 \\ & & & \\ 296-302 & 1,961 & 2,263 & 2,025 \\ 234-240 & 1,931 & 2,171 & 1,983 \\ 64-70 & 1,901 & 1,971 & 1,931 \\ 226-232 & 1,924 & 2,156 & 1,964 \\ 234-240 & 1,921 & 2,161 & 1,976 \\ 199-205 & 1,933 & 2,138 & 2,046 \\ 207-219 & 1,914 & 2,133 & 1,984 \\ 183-195 & 1,915 & 2,110 & 1,960\end{array}$

Antelope Creek aquifer

$\begin{array}{cccc}236-242 & 1,680.7 & 1,922.7 & 1,854.3 \\ 100-110 & 1,812.5 & 1,922.5 & 1,877.6 \\ 90-100 & 1,830.0 & 1,930.0 & 1,872.1 \\ 117-120 & 1,821.0 & 1,941.0 & 1,888.2 \\ 80-86 & 1,864.0 & 1,950.2 & 1,916.8 \\ & & 1,8 & 1,907.3 \\ 74-80 & 1,870.0 & 1,950.0 & 1,847.3 \\ 210-216 & 1,692.7 & 1,908.7 & 1,879.1 \\ 90-100 & 1,808.8 & 1,908.8 & 1,847.1 \\ 338-341 & 1,569.1 & 1,910.1 & 1,847.4 \\ 218-224 & 1,629 & 1,852.8 & 1,859.4 \\ 58-64 & 1,819.0 & 1,883 & \end{array}$

Lake Sakakawea
$1,854.3$

$1,877.6$

$1,872.1$

1,888.?

$1,907.3$

$1,847.3$

$1,879.1$

$1,847.1$

$1,859.4$

1,848 
The Sentinel Butte Member consists mostly of fine-grained clastic sedimentary rocks, and generally is not an aquifer. Fine grain size and the large clay mineral content result in minimal hydraulic conductivity. However, individual beds of poorly cemented sandstone and lignite in the member may have greater hydraulic conductivity.

Generally the sandstones occurring in the Sentinel Butte in the study area are poorly cemented but, because they are poorly sorted and have large clay content, they have limited hydraulic conductivity. The porosity of the sandstone ranges from less than 5 percent to a maximum of about 45 percent. The aggregate sandstone thickness in the Sentinel Butte varies greatiy (fig. 12). Most of the sandstone occurs as a basal unit (fig. 7), which forms the basal Sentinel Butte aquifer.

Alger (1966) describes a technique for determining the hydraulic conductivity of sand aquifers from resistivity logs. Croft (1971) used this technique in a study of the Fox Hills Sandstone in North Dakota. Croft's study showed close agreement between hydraulic conductivity calculated by Alger's method and that determined by aquifer testing. Analyses of resistivity logs from the basal Sentinel Butte sandstone using Alger's method yielded values of hydraulic conductivity that ranged from 2 to 6 $\mathrm{ft} / \mathrm{d}$.

Lignite beds form aquifers in many parts of western North Dakota. The Beulah-Zap lignite bed forms a shallow confined aquifer on the western side of the study area. Hydraulic conductivity and direction of ground-water flow in this lignite bed probably are controlled by fractures and joints, and therefore, vary from one location to another. Analyses of the Beulah-Zap lignite aquifer using Alger's method yielded fairly consistent values for hydraulic conductivity of 0.5 to $2.0 \mathrm{ft} / \mathrm{d}$. However, the validity of this type of analysis for aquifer material such as lignite is not clear.

The horizontal hydraulic gradient in the Beulah-Zap lignite aquifer (fig. 13) is about $25 \mathrm{ft} / \mathrm{mi}$. There are insufficient data on horizontal permeabilities in the lignite to estimate average velocity. The horizontal gradient in the basal Sentinel Butte sandstone could not be defined with available data (fig. $14)$.

The water-level data for the basal Sentinel Butte sandstone ( fig. 14) do not define a gradient across the study area and appear to be controlled by the level of Lake Sakakawea. The lake probably acts as a constant hydraulic-head boundary for the aquifer in the basal Sentinel Butte sandstone and may provide 


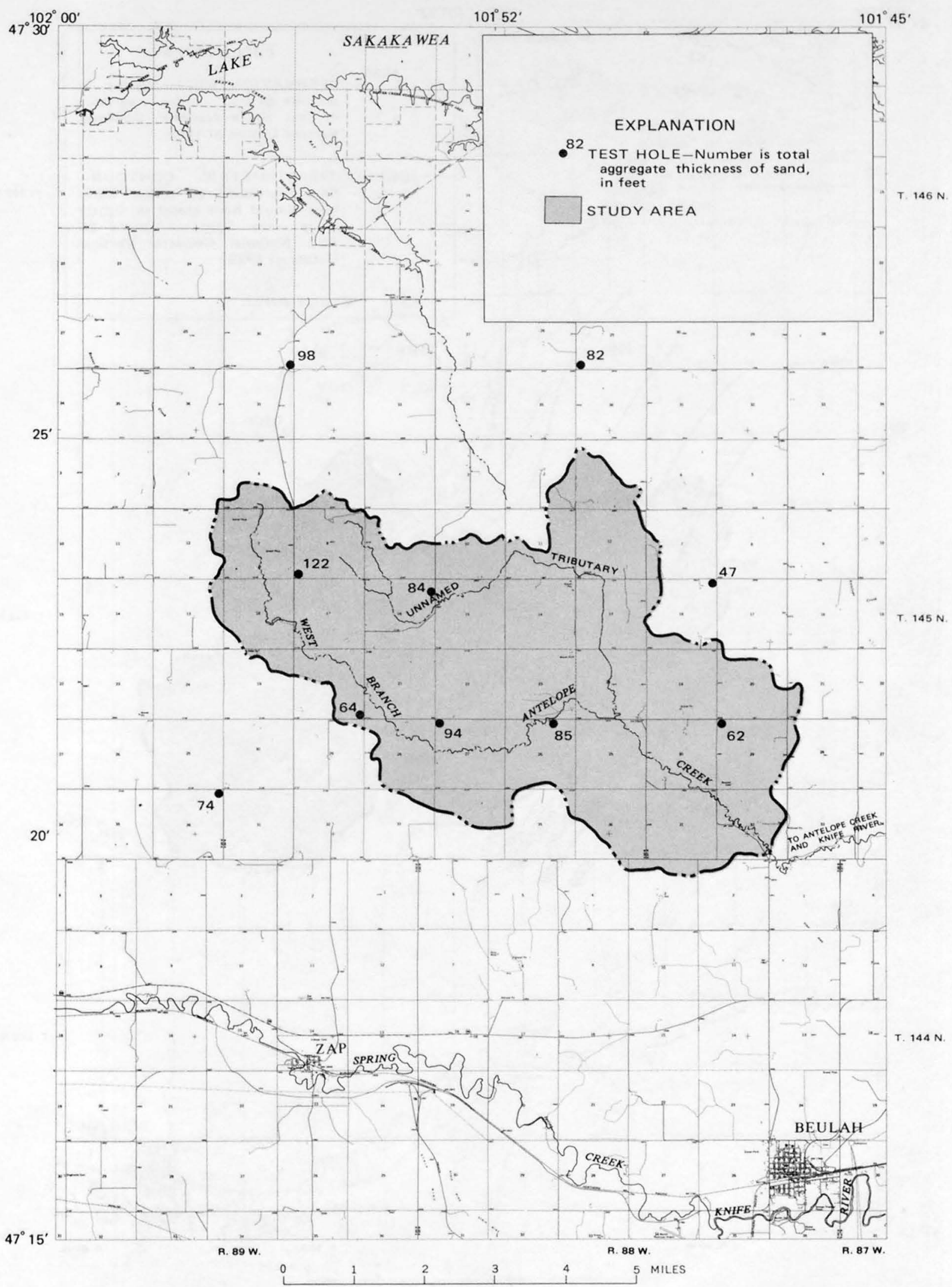

FIGURE 12.-Aggregate sandstone thickness of the Sentinel Butte Member in the study area and vicinity. 


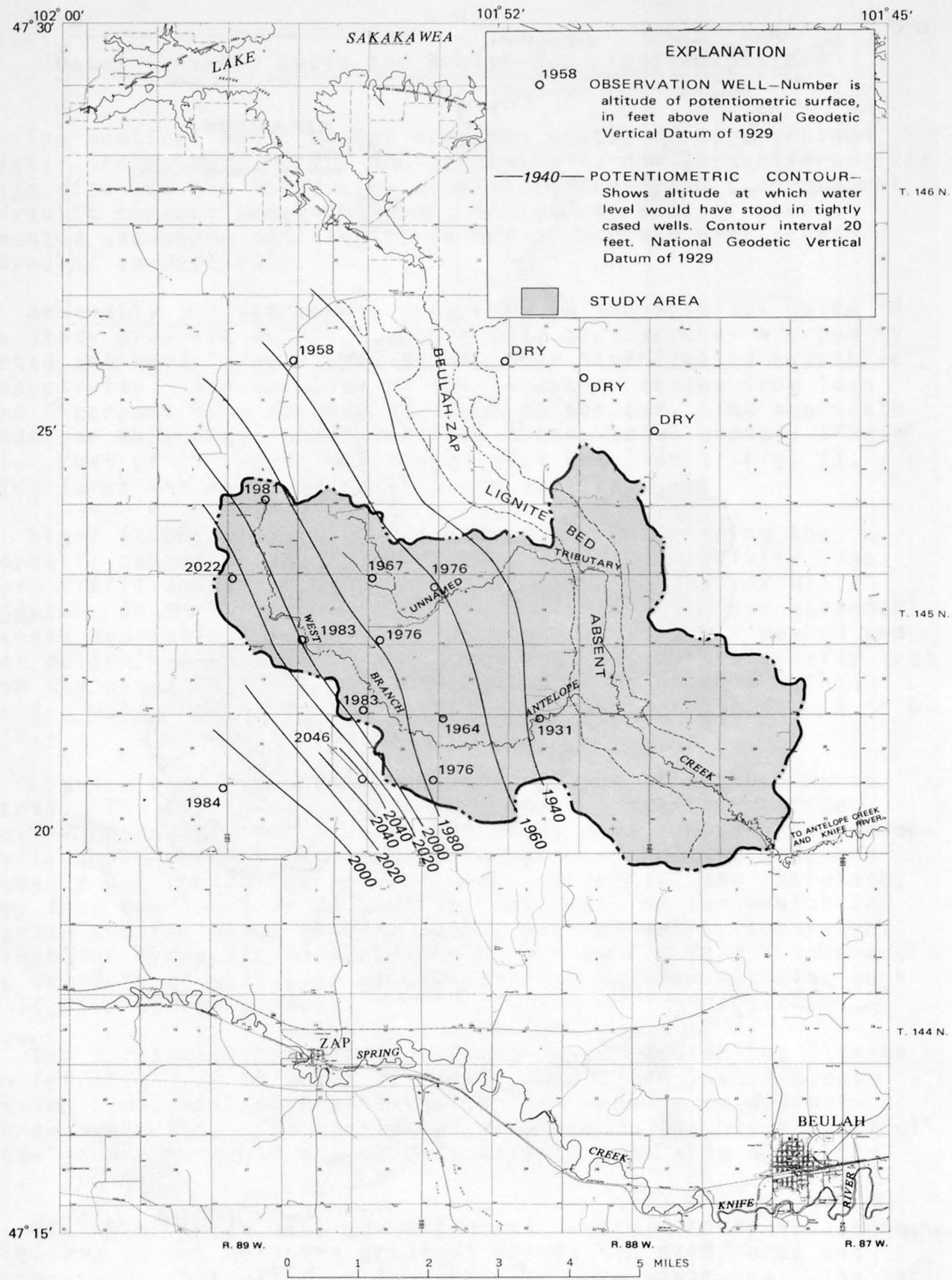

FIGURE 13.-Potentiometric surface of the Beulah-Zap lignite aquifer, July 1978, in the study area and vicinity. 


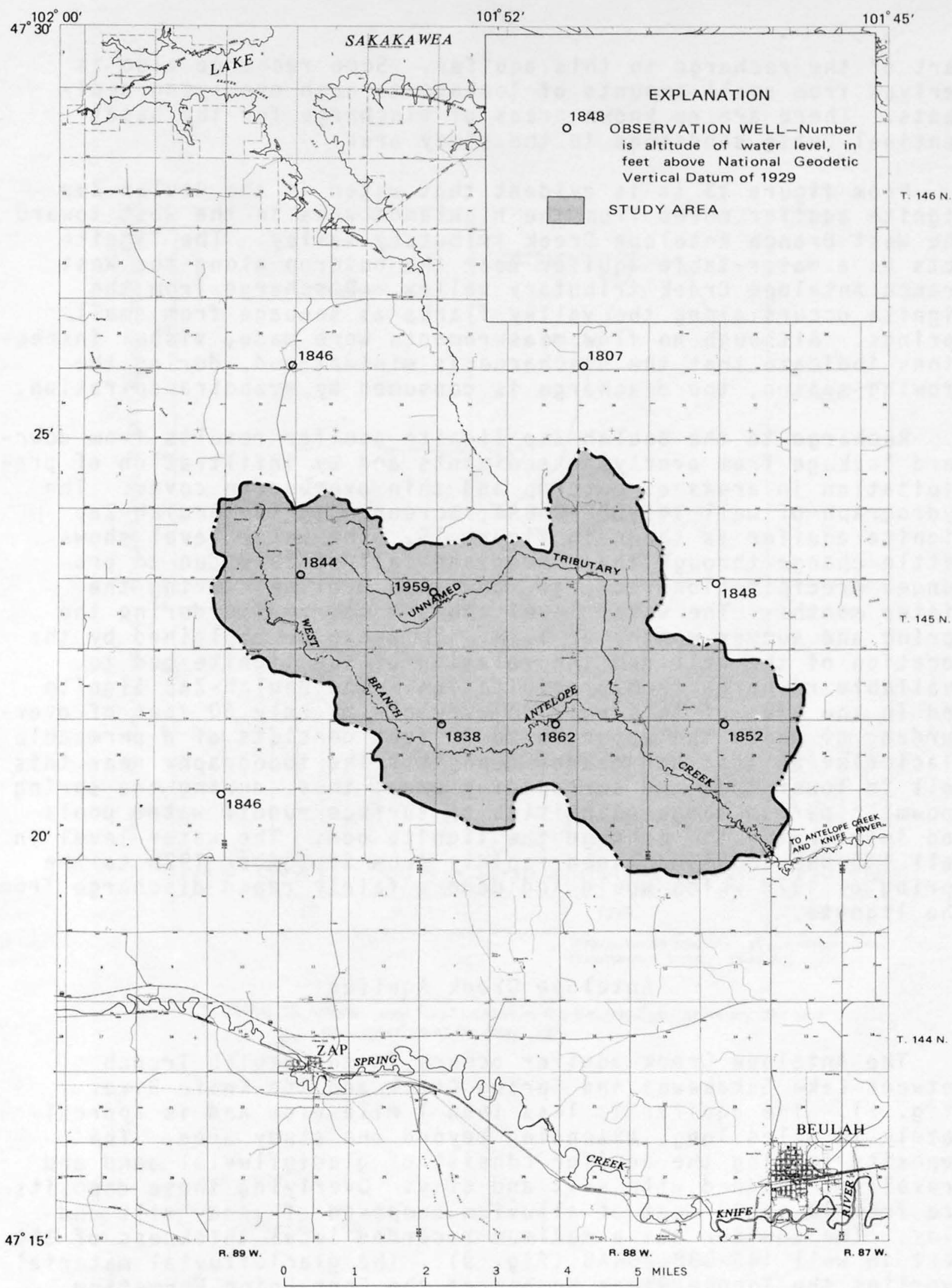

FIGURE 14.-Water levels in observation wells in the basal sandstone of the Sentinel Butte Member, October 1978, in the study area and vicinity. 
part of the recharge to this aquifer. Some recharge also is derived from small amounts of leakage through overlying sediments. There are no known areas of discharge for the basal Sentinel Butte sandstone in the study area.

From figure 13 it is evident that water in the Beulah-Zap lignite aquifer moves from the highlands area in the west toward the West Branch Antelope Creek tributary valley. The lignite acts as a water-table aquifer near the outcrop along the West Branch Antelope Creek tributary valley. Discharge from the lignite occurs along the valley flanks as seepage from small springs. Although no flow measurements were made, visual inspections indicate that the discharge is minimal and, during the growing season, the discharge is consumed by evapotranspiration.

Recharge to the Beulah-Zap lignite aquifer results from downward leakage from overlying sediments and by infiltration of precipitation in areas of outcrop and thin overburden cover. The hydrograph of well 145-088-26BAA, screened in the Beulah-Zap 1 ignite aquifer is shown in figure 15. The water level shows little change through the summer and fall of 1977 due to prolonged precipitation recharge, and then declines during the winter months. The water level shows a sharp rise during the spring and summer months of 1978. This can be explained by the location of the well and the relation of the lignite bed to available recharge from precipitation. The Beulah-Zap lignite bed in the area of this well is overlain by only 60 feet of overburden, of which the upper 20 to 30 feet consists of a permeable glaciofluvial sand and gravel deposit. The topography near this well is lower than the surrounding area; thus, during the spring snowmelt period large quantities of surface runoff water pools and infiltrates to recharge the 1 ignite bed. The water level in well 145-088-26BAA declined rapidly from September 1978 to the spring of 1979 which would indicate a fairly rapid discharge from the lignite.

\section{Antelope Creek Aquifer}

The Antelope Creek aquifer occurs in the Beulah Trench between Lake Sakakawea and Spring Creek and the Knife River (fig. 5). The aquifer is less than 1 mile wide and is approximately 16 miles long, extending beyond the study area. The deposits forming the aquifer consist of glaciofluvial sand and gravel interbedded with silt and clay. Overlying these deposits are from 10 to 30 feet of alluvium composed of sandy silt and clay. The aquifer has a maximum recorded local thickness of 350 feet in well 145-088-25BAB (fig.9). The glaciofluvial material overlies the Tongue River Member of the Fort Union Formation (fig. 9). The sand and gravel deposits of the aquifer for the most part are unconsolidated and very permeable. 

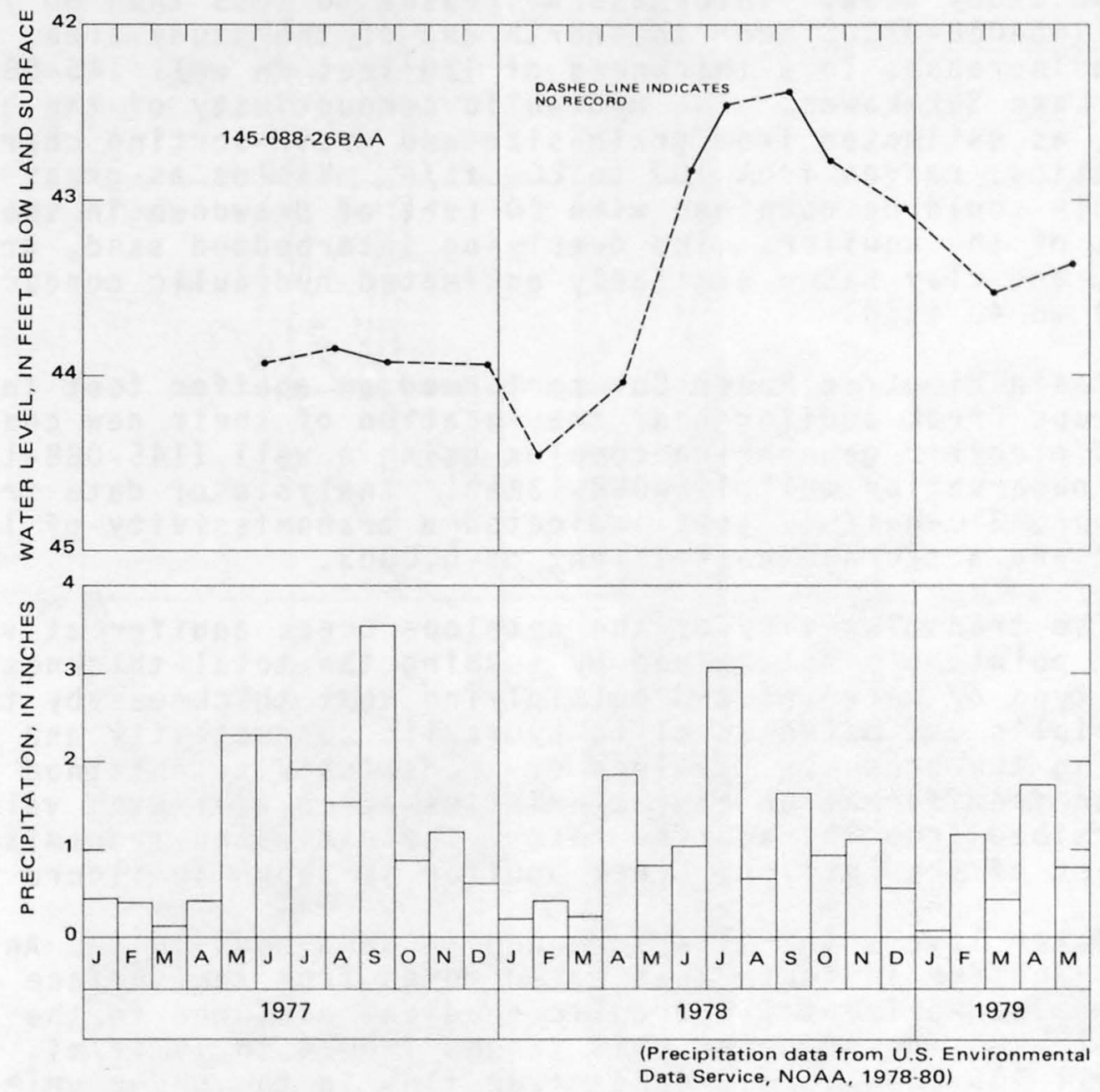

FIGURE 15.-Water-level fluctuations in the Beulah-Zap lignite aquifer and precipitation at Beulah. 
The Antelope Creek aquifer (fig. 9) has two basic units; a thick and continuous sand and gravel unit at the base, overlain by a unit of interbedded sand, gravel, silt, and clay. The basal sand unit has a maximum known thickness of 140 feet in well 145-088-25BAB in the center of the aquifer near the southern end of the study area. Thickness decreases to less than 50 feet in well 145-088-02CCC near the north end of the study area, and again increases to a thickness of 120 feet in we11 146-088-21DDD near Lake Sakakawea. The hydraulic conductivity of the basal unit, as estimated from grain-size and grain-sorting characteristics, ranges from 100 to $200 \mathrm{ft} / \mathrm{d}$. Yields as great as 800 gal/min could be obtained with 20 feet of drawdown in the thicker parts of the aquifer. The overlying interbedded sand, gravel, silt, and clay has a similarly estimated hydraulic conductivity of 10 to $40 \mathrm{ft} / \mathrm{d}$.

Basin Electric Power Co. performed an aquifer test in the Antelope Creek aquifer near the location of their new coalfired electric generating complex using a well (145-088-12CDC) near observation well 145-088-13BAB. Analysis of data from the 72-hour, 310-gal/min test indicated a transmissivity of 18,000 $\mathrm{ft}^{2} / \mathrm{d}$ and a storage coefficient of 0.0003 .

The transmissivity of the Antelope Creek aquifer at various other points was determined by summing the total thickness of each type of material and multiplying that thickness by the material's estimated specific hydraulic conductivity and then summing the products. Values of transmissivity obtained by estimation from formation characteristics agree well with values determined from the aquifer test. The estimated transmissivity of part of the Antelope Creek aquifer is shown in figure 16.

Water levels in wells screened in sand beds in the Antelope Creek aquifer indicate that water moves from the surface downward. The horizontal hydraulic gradient measured in the sand and gravel beds in the upper unit ranges from 4 to $16 \mathrm{ft} / \mathrm{mi}$. North of well 145-088-13BAB ground-water flow in the upper unit is northward toward Lake Sakakawea, and south of this well flow is southward (fig. 9) toward the knife River. The area near this well is a ground-water divide for the upper unit.

The upper unit of the Antelope Creek aquifer is recharged by infiltration of precipitation. The relationship of precipitation and the water levels in wells screened in the upper unit of the aquifer is shown in figure 17. The water-level decline in well 145-088-25ABB2 from Ju1y 1977 to March 1978 indicates a decrease in the amount of water in storage in the aquifer during the fall and winter. Water levels in the well rose sharply from April through June 1978 and maintained a high level through late fall and winter, indicating rapid infiltration and continuing recharge from snowmelt and rainfall during the spring and summer. The maintenance of high levels into the winter of 1978-79 and not 


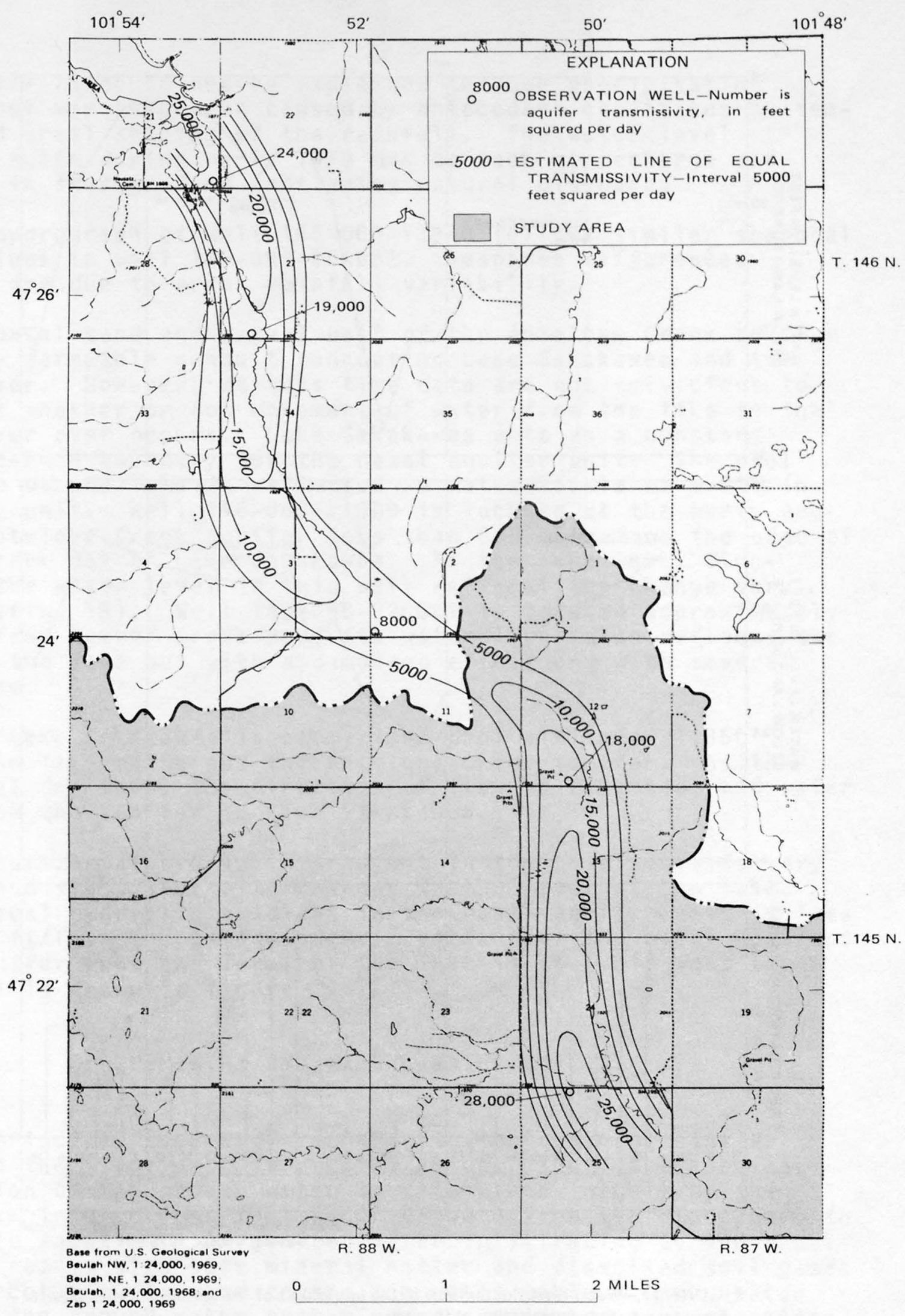

FIGURE 16.-Estimated transmissivities of the Antelope Creek aquifer, La!'e Sakakawea to south-central part of study area. 

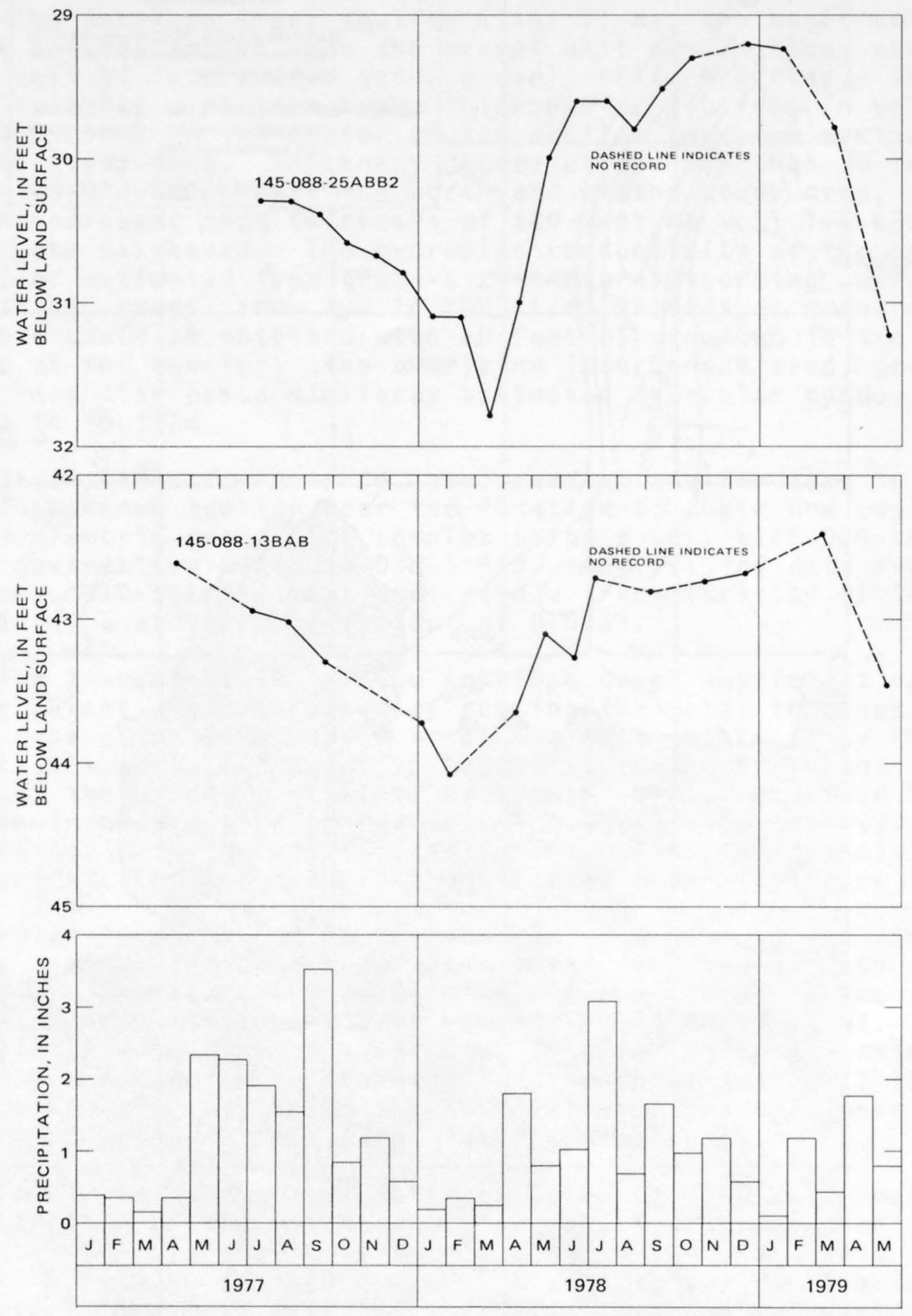

(Precipitation data from U.S. Environmental Data Service, NOAA, 1978-80)

FIGURE 17.-Water-level fluctuations in the upper unit of the Antelope Creek aquifer and precipitation at Beulah. 
during 1977-78 could not be explained through precipitation records but may have been caused by antecedent conditions or temporal and areal spacing of the rainfall. The water level declined again during early 1979 due to lack of recharge and decrease in storage from continuing natural discharge.

The hydrograph of well 145-088-13BAB follows similar seasonal fluctuations to well 145-088-25ABB2. Response differences probably are due to areal rainfall variability.

The basal sand and gravel unit of the Antelope Creek aquifer is a very permeable conduit connecting Lake Sakakawea and the Knife River. However, at this time data are not sufficient to determine whether or not movement of water from the lake to the Knife River ever occurs. Lake Sakakawea acts as a constant hydraulic-head boundary for the basal aquifer unit. The pool elevation of the lake is reflected in water levels of wells in the basal unit. Well 146-088-210DD is located at the north end of the Antelope Creek aquifer less than 0.5 mile from the edge of Beaver Creek Bay of Lake Sakakawea. As the lake level fluctuates, the water level in this well reflects the change very rapidly (fig. 18). Well 145-088-02CCCl is located approximately 4 miles from Beaver Creek Bay; its water level also reflects the level of the lake but with a dampened effect and with several days delay.

When Lake Sakakawea is at maximum pool altitude $(1,850$ feet), the lake recharges the Antelope Creek aquifer. As the lake level declines, the direction of flow is reversed, and water moves from the aquifer to Lake Sakakawea.

The horizontal hydraulic gradient in the basal unit is very gradual and fluctuates with changes in the level of the lake. The vertical hydraulic gradient in the basal aquifer unit is less than $0.1 \mathrm{ft} / \mathrm{ft}$. The potentiometric surface of the basal Antelope Creek aquifer when the level of the lake is at 1,845 feet (June 15,1978 ) is shown in figure 19.

\section{GEOCHEMISTRY AND GROUND-WATER QUALITY}

The principal source of recharge to the regional aquifer system in the study area is precipitation. Thus, the chemical composition of the ground water is determined largely by the water-rock interactions that occur enroute from the atmosphere to the sample location. Oxygenated water infiltrating during precipitation reacts with some mineral matter and dissolved soil gases as it percolates downward toward the water table. Thus, water entering the ground-water system usually contains concentrations of oxidized solutes alien to the reducing environment below the water table. Further reaction between the water and rocks will continue as the ground water migrates downward and laterally. 


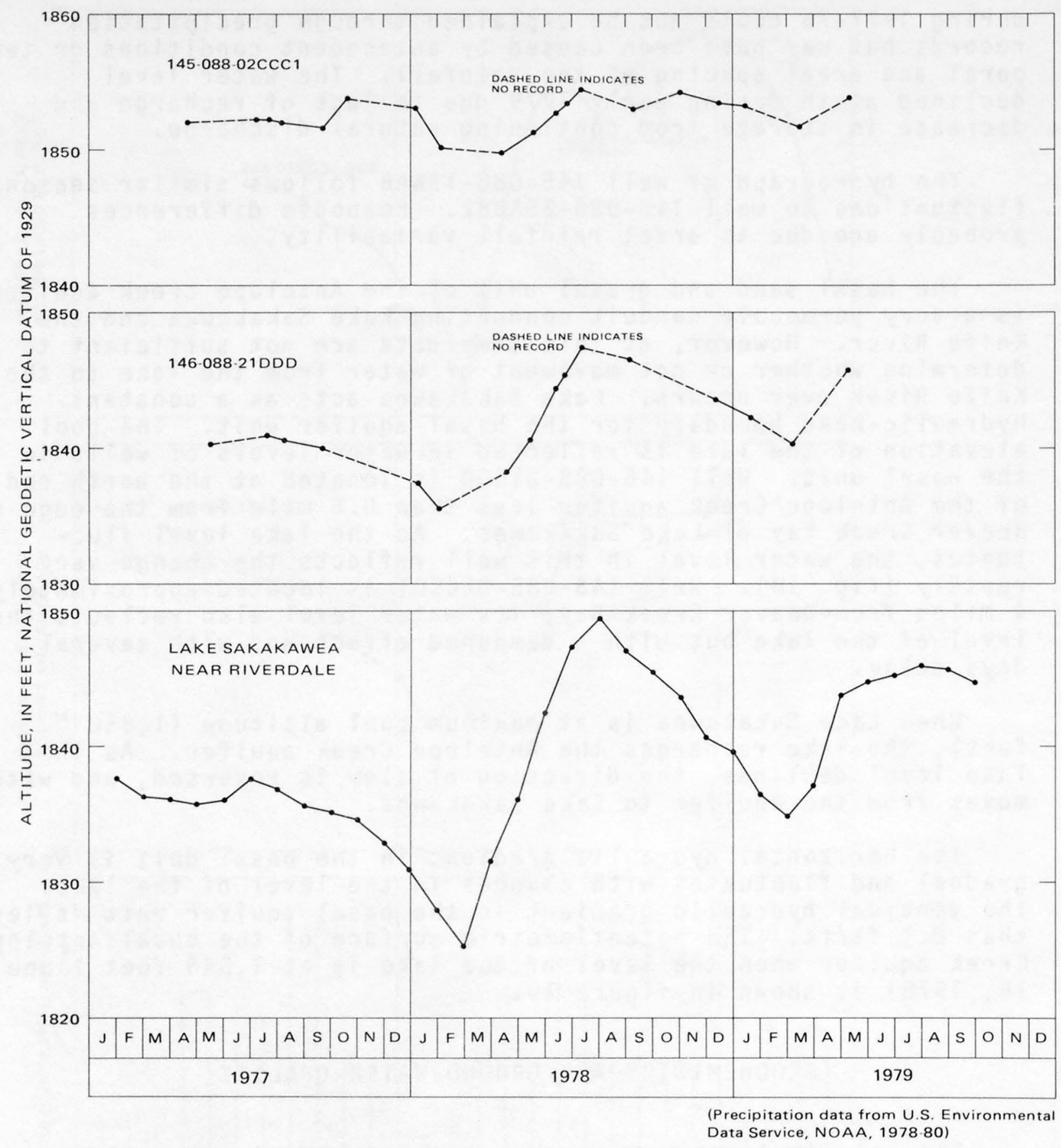

FIGURE 18.-Water-level fluctuations in the basal unit of the Antelope Creek aquifer and level of Lake Sakakawea. 


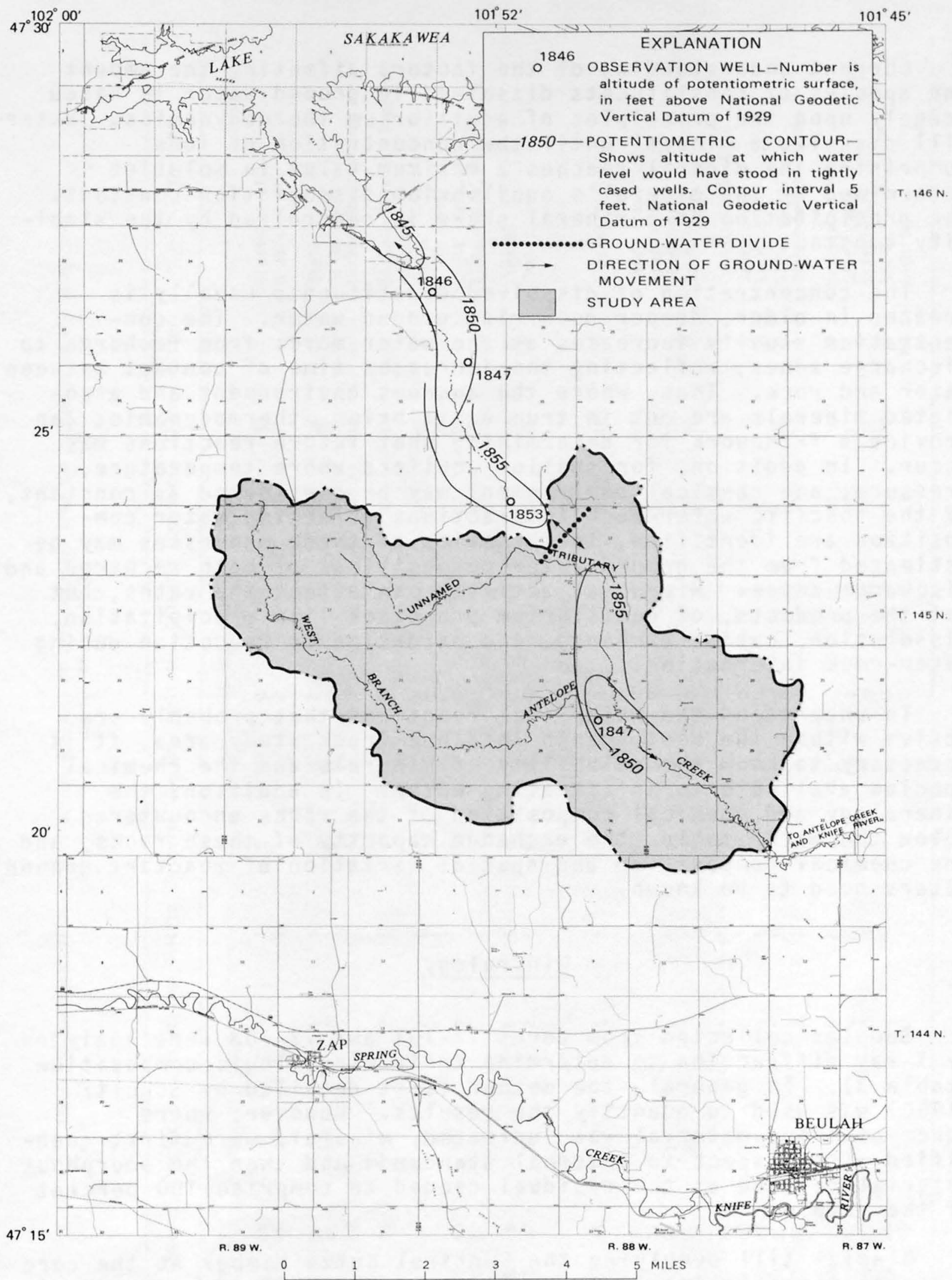

FIGURE 19.-Potentiometric surface of the basal unit of Antelope Creek aquifer, September 1978, with stage of Lake Sakakawea at 1,845 feet, Lake Sakakawea to south-central part of study area. 
Current understanding of the factors affecting the amount and species of constituents dissolved in ground water is based largely upon the principles of equilibrium thermodynamics. Water will dissolve a mineral until the concentration of ions comprising the mineral reaches a maximum value in solution determined by the mineral's equilibrium dissociation constant. The precipitation of a mineral phase is controlled by the stability constant.

The concentration of dissolved constituents usually is greater in older, deeper occurring ground water. The concentration usualiy increases as the water moves from recharge to discharge zones, reflecting the increased time of contact between water and rock. Thus, where the aqueous environment and associated minerals are not in true equilibrium, thermodynamics can provide a framework for determining what future reactions may occur. In addition, for shallow aquifers where temperature, pressure, and chemical environment may be considered as constant, if the specific water-rock interactions affecting water composition are identified, the kinetics of these processes may be estimated from the ground-water compositions of both recharge and discharge zones. Microbial activity can affect the rates, but not the products, of equilibrium processes like precipitation, dissolution, cation exchange, and oxidation or reduction during water-rock interaction.

To understand the water-rock reactions that probably are active within the West Branch Antelope Creek study area, it is necessary to know the solubility of minerals and the chemical species available to infiltrating water. In addition, the mineralogy and chemical composition of the rocks encountered below the water table, the exchange capacity of these rocks, and the chemical composition and spatial variation of reactant ground waters need to be known.

\section{Mineralogy}

Samples collected from cores 77-101 and 77-103 were analyzed by $x$-ray diffraction to determine their mineralogic composition (table 3). In general, the method first detailed by Schultz (1960) was used to quantify the results. However, where noncrystalline material was indicated, minerals were first quantified with respect to internal standards and then the amorphous material defined as the residual needed to comprise 100 percent of the sample.

Glacial till overlying the Sentinel Butte Member at the core sites is mineralogically very uniform. The till is composed of 25 to 35 percent quartz, 25 to 33 percent smectite, and 10 to 33 percent illite. Dolomite can locally exceed 10 percent of the til1. 
TABLE 3.--Quantitative X-ray diffraction analyses of core material from two locations in the study area (percent minerals)

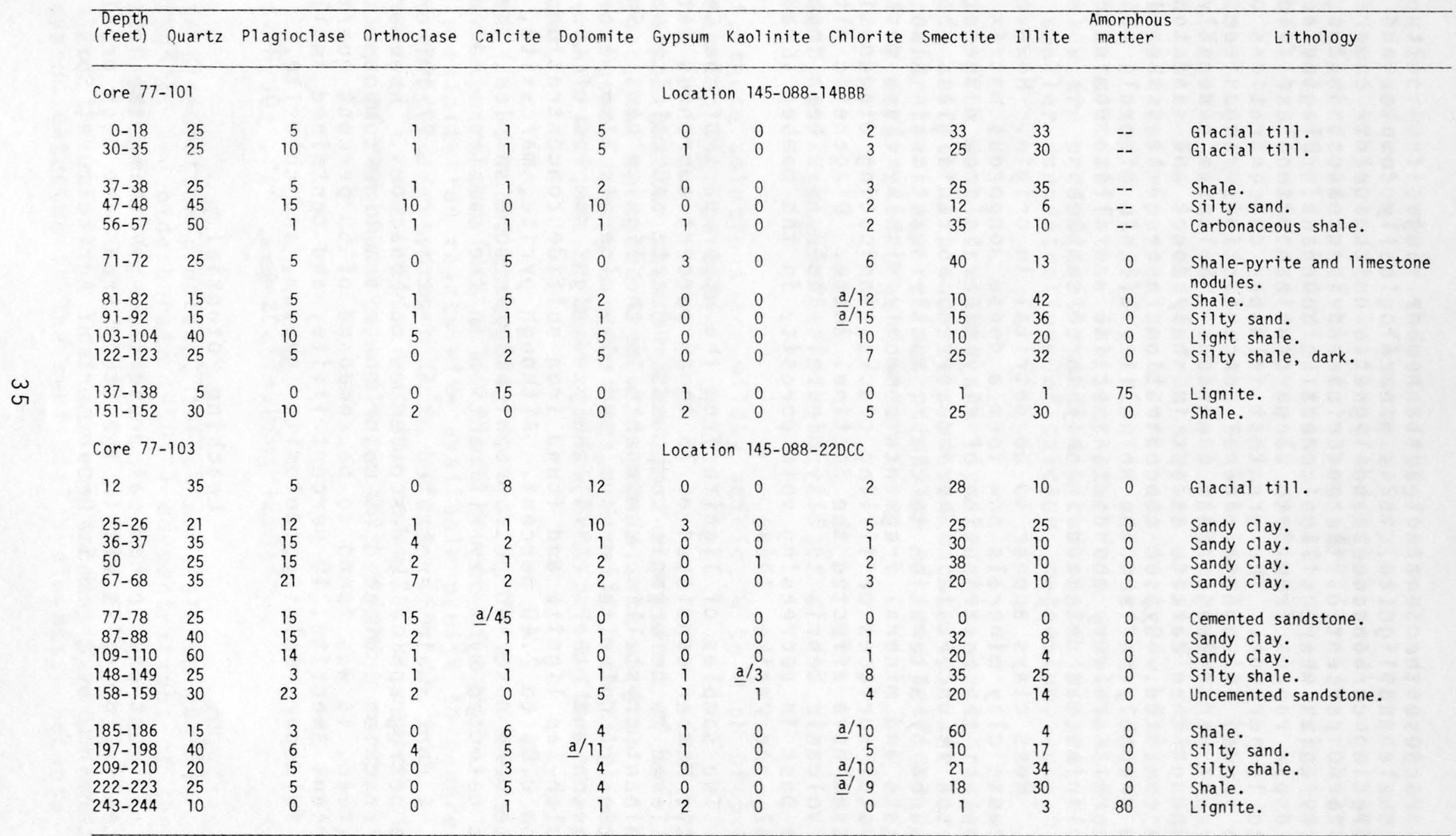

a/ Presence of this mineral phase confirmed; quantity estimated by the difference method. 
Because the Sentinel Butte Member ranges from silty sandstone to shale and lignite, it is mineralogically complex and variable. Excluding carbonaceous and lignitic units, quartz comprises from 15 to 60 percent of the material and is greatest in the sandy and silty units where silica cement is abundant. Plagioclase

feldspar ranges from 3 to 23 percent and orthoclase feldspar from 1 to 15 percent. The greatest feldspar concentrations occur in the sands. Carbonate mineral concentrations range from 1 to 45 percent and average about 6 percent. Dolomite generally is more abundant than calcite except in shaly zones and sandstones that are cemented. Gypsum concentrations average less than 1 percent, and probably reflect the solubility of this mineral. clay minerals are very abundant; smectite and illite dominate. Kaolinite was detected in only three samples.

Most clays appear to be detrital in origin. However, because clay minerals now form a dense nonporous matrix in most samples, the contribution of clay minerals from diagenetic processes is uncertain. Where observed, volcanic glass shards are clouded by alteration to clays, mostiy smectites. Also, 1ithiclasts and mineral fragments commonly display clays masking crystal surfaces or filling cracks, indicating diagenetic processes have affected the Sentinel Butte. Diagenetic alteration of volcanic debris to clay minerals could have been important in the past in decreasing void porosity in the member (Krauskopf, 1967 , and Papike, 1969).

Two samples of lignite from the upper part of the Sentinel Butte Member consisted of 75 to 80 percent amorphous matter believed to be organic compounds. Quartz and calcite were the dominant crystalline components in the lignite beds. Small quantities of dolomite, gypsum, and clay minerals also were detected. Swanson and others (1974) analyzed eight samples of the Beulah-zap lignite and found iron sulfide concentrations ranging from 0.08 to 2.40 percent. Although pyrite, marcasite, and hematite were observed petrographically in some samples, they were not detected by $x$-ray diffraction in the samples studied.

A dark shale penetrated at 56 feet in core 77-101 originally was petrographically described as carbonaceous. However, $x-r a y$ diffraction indicated no major noncrystalline component. Instead, it was found to be composed of 50 percent quartz, 35 percent smectite, 10 percent $i 11$ ite, and contained small amounts of feldspar, calcite, dolomite, gypsum, and chlorite.

\section{Leaching Potential}

As most physiochemical properties governing the leaching potential of soils within the study area have been previously determined by the U.S. Department of Agriculture, Soil 
Conservation Service (1978), this investigation centered on the properties of rock below the soil zone. Samples collected from core 77-103 were subjected to leaching and soluble-salt analyses using the procedures of Sandoval and others (1973). The results of these analyses (table 4) indicate the locations and relative amounts of available water-soluble ionic species.

Leachates from samples above the Beulah-Zap lignite bed (shallower than 235 feet) were alkaline, with a maximum pH of 9.60 at 158 feet. The leachate from samples above 87 feet generally were calcium-magnesium bicarbonate in type. Only leachate from a sample at 25 feet rich in secondary gypsum is enriched in calcium sulfate. The leachates from samples at 87 feet and below are predominantly sodium bicarbonate in type, possessing smaller concentrations of calcium, magnesium, and sulfate.

Leachates from samples within the lignite zone were enriched in sodium and sulfate with some calcium and magnesium. The large sulfate concentrations may reflect oxidation of iron sulfides in the lignite by oxygenated ground water:

$$
2 \mathrm{FeS}_{2}(\mathrm{~s})+7 \mathrm{O}_{2}(\mathrm{~g})+2 \mathrm{H}_{2} \mathrm{O} \rightleftarrows 2 \mathrm{Fe}^{2+}+2 \mathrm{H}_{2} \mathrm{SO}_{4}+2 \mathrm{SO}_{4}{ }^{2-}
$$

As a result, these solutions are mildly acidic, with a pH of 5.00 in the Beulah-Zap lignite bed.

At $\mathrm{pH}$ values greater than $\mathrm{pH}=3$ and in the presence of sufficient oxygen, the released iron will precipitate as iron sesquioxides, usually as grain coatings. Hematitic coatings were observed in thin sections of some shallow sentinel Butte sedimentary rocks.

Reaction (1) is rapid especially in near-surface sediments where the atmosphere provides a limitless source of oxygen. oxygenated precipitation reacts with available pyrite to generate pore fluids enriched in hydrogen $\left(\mathrm{H}^{+}\right)$, sulfate $\left(\mathrm{SO}_{4}{ }^{-}\right)$, and ferrous iron ( $\mathrm{Fe}^{2+}$ ) ions. This reaction normally is coupled with the dissolution of carbonate minerals by this slightly acidic water:

$$
2 \mathrm{CaCO}_{3}(\mathrm{~s})+\mathrm{H}_{2} \mathrm{SO}_{4}+\mathrm{SO}_{4} 2-\rightleftarrows 2 \mathrm{Ca}^{2+}+2 \mathrm{HCO}_{3}{ }^{-}+2 \mathrm{SO}_{4}^{2-}
$$

As carbonate dissolution proceeds, the $\mathrm{pH}$ and calcium $\left(\mathrm{Ca}^{2+}\right)$, magnesium $\left(\mathrm{Mg}^{2+}\right)$, and bicarbonate $\left(\mathrm{HCO}_{3}{ }^{-}\right)$concentrations of the water may be expected to increase.

Removal of the sulfate by calcium may account for the small amount of gypsum detected in the surficial sediments. Because 
TABLE 4.--Composition of leachate from samples of core 77-103

\begin{tabular}{|c|c|c|c|c|c|c|c|c|c|c|}
\hline \multirow[b]{2}{*}{$\begin{array}{l}\text { Sample } \\
\text { depth } \\
\text { (feet) }\end{array}$} & \multirow{2}{*}{$\begin{array}{l}\text { Specific } \\
\text { conductance } \\
\text { (micromhos per } \\
\text { centimeter } \\
\text { at } 25^{\circ} \mathrm{Cel} \text { sius) }\end{array}$} & \multirow{2}{*}{$\stackrel{\mathrm{pH}}{\text { (units) }}$} & \multicolumn{8}{|c|}{ Milliequivalents per 100 grams of leachate } \\
\hline & & & $\begin{array}{l}\text { Bicar- } \\
\text { bonate } \\
\left(\mathrm{HCO}_{3}^{-}\right)\end{array}$ & $\begin{array}{l}\text { Sulfate } \\
\left(\mathrm{SO}_{4}{ }^{2-}\right)\end{array}$ & $\begin{array}{c}\text { Chloride } \\
\left(\mathrm{Cl}^{-}\right)\end{array}$ & $\begin{array}{c}\text { Carbo- } \\
\text { nate } \\
\left(\mathrm{CO}_{3}{ }^{2-}\right.\end{array}$ & $\begin{array}{l}\text { Calcium } \\
\left(\mathrm{Ca}^{2+}\right)\end{array}$ & $\begin{array}{c}\text { Magnes- } \\
\text { ium } \\
\left(\mathrm{Mg}^{2+}\right)\end{array}$ & $\begin{array}{l}\text { Sodium } \\
\left(\mathrm{Na}^{+}\right)\end{array}$ & $\begin{array}{l}\text { Potas- } \\
\text { sium } \\
\left(K^{+}\right)\end{array}$ \\
\hline $\begin{array}{l}12 \\
25 \\
36 \\
50 \\
67\end{array}$ & $\begin{array}{r}133.0 \\
1,090.0 \\
81.0 \\
51.7 \\
105.6\end{array}$ & $\begin{array}{l}8.52 \\
8.90 \\
7.95 \\
7.74 \\
8.41\end{array}$ & $\begin{array}{r}0.92 \\
.80 \\
.50 \\
.47 \\
1.10\end{array}$ & $\begin{array}{r}0.50 \\
11.30 \\
.27 \\
.30 \\
.30\end{array}$ & $\begin{array}{r}0.15 \\
.14 \\
.05 \\
.06 \\
.04\end{array}$ & $\begin{array}{l}0.10 \\
.12 \\
0 \\
0 \\
.05\end{array}$ & $\begin{array}{r}0.68 \\
8.90 \\
.23 \\
.40 \\
.30\end{array}$ & $\begin{array}{r}0.50 \\
2.70 \\
.20 \\
.04 \\
.44\end{array}$ & $\begin{array}{r}0.34 \\
.50 \\
.35 \\
.38 \\
.66\end{array}$ & $\begin{array}{r}0.05 \\
.04 \\
.05 \\
.02 \\
.04\end{array}$ \\
\hline $\begin{array}{r}87 \\
109 \\
148 \\
158 \\
168\end{array}$ & $\begin{array}{r}97.1 \\
59.0 \\
309.0 \\
372.0 \\
502.0\end{array}$ & $\begin{array}{l}7.90 \\
6.92 \\
9.07 \\
9.60 \\
8.40\end{array}$ & $\begin{array}{l}.58 \\
.37 \\
3.30 \\
2.75 \\
2.22\end{array}$ & $\begin{array}{l}.47 \\
.34 \\
.90 \\
1.20 \\
3.35\end{array}$ & $\begin{array}{l}.06 \\
.07 \\
.22 \\
.14 \\
.10\end{array}$ & $\begin{array}{l}0 \\
0 \\
.20 \\
.24 \\
0^{.24}\end{array}$ & $\begin{array}{l}.50 \\
.33 \\
.35 \\
.20 \\
.27\end{array}$ & $\begin{array}{l}.05 \\
.10 \\
.15 \\
.10 \\
.08\end{array}$ & $\begin{array}{l}.60 \\
.26 \\
3.85 \\
3.90 \\
5.33\end{array}$ & $\begin{array}{l}.01 \\
.04 \\
.08 \\
.08 \\
.02\end{array}$ \\
\hline $\begin{array}{l}185 \\
197 \\
209 \\
223 \\
233\end{array}$ & $\begin{array}{l}568.0 \\
550.0 \\
544.0 \\
531.0 \\
372.0\end{array}$ & $\begin{array}{l}8.98 \\
9.47 \\
9.10 \\
9.11 \\
8.20\end{array}$ & $\begin{array}{l}4.83 \\
3.65 \\
6.98 \\
5.22 \\
2.91\end{array}$ & $\begin{array}{l}2.00 \\
2.13 \\
1.05 \\
1.35 \\
1.70\end{array}$ & $\begin{array}{l}.11 \\
.13 \\
.14 \\
.11 \\
.16\end{array}$ & $\begin{array}{l}.19 \\
.16 \\
.27 \\
.30 \\
0\end{array}$ & $\begin{array}{l}.46 \\
.12 \\
.20 \\
.26 \\
.20\end{array}$ & $\begin{array}{l}.04 \\
.10 \\
.31 \\
.04 \\
.04\end{array}$ & $\begin{array}{l}6.74 \\
5.98 \\
8.16 \\
6.76 \\
4.57\end{array}$ & $\begin{array}{l}.03 \\
.02 \\
.05 \\
.03 \\
.04\end{array}$ \\
\hline $\begin{array}{l}243 \\
266\end{array}$ & $\begin{array}{l}2,270.0 \\
1,056.0\end{array}$ & $\begin{array}{l}5.00 \\
6.23\end{array}$ & $\begin{array}{l}.25 \\
.65\end{array}$ & $\begin{array}{l}24.50 \\
10.45\end{array}$ & $\begin{array}{l}.07 \\
.08\end{array}$ & $\begin{array}{l}0 \\
0\end{array}$ & $\begin{array}{r}4.15 \\
.30\end{array}$ & $\begin{array}{r}3.30 \\
.05\end{array}$ & $\begin{array}{l}17.41 \\
10.55\end{array}$ & $\begin{array}{l}.08 \\
.03\end{array}$ \\
\hline
\end{tabular}


of the infrequency of infiltration in the area, pore water usually undergoes concentration by evaporation resulting in locallized precipitation of gypsum that may temporarily decrease sulfate concentrations in the water passing to the water table. However, subsequent infiltration of precipitation can produce even more concentrated sulfate waters upon dissolution of this secondary gypsum. Similar dissolution of carbonate minerals present in rocks underlying the Beulah-zap lignite by sulfate waters may be expected to have a buffering effect on this slightly acidic leachate, neutralizing the sulfuric acid and restoring the water to bicarbonate type.

The results of the leaching experiments also indicate that the amount of currently available leachable material increases with depth, perhaps indicating a decrease in water reactivity with depth due to progressive saturation of downward percolating water with the soluble material. Presumably, future leaching will be effective at progressively deeper levels.

\section{Cation-Exchange Potential}

From a general chemical point of view, the most important class of minerals in soils and rock are those having ion-exchange capacity. These minerals possess most of the total inorganic surface area in soils and many sedimentary rocks (Bolt and Bruggenwert, 1976), thus having a large potential for water-rock interaction. Within the unsaturated zone, these same minerals also have a major effect on water retention and other physical properties. Further, as the rates of ion-exchange reactions are fast, relative to most other types of water-rock interaction (Garrels and Mackenzie, 1967), the effects of these minerals on water chemistry is most readily noticeable.

Samples obtained from core 77-103 at the same intervals selected for mineralogic determination were subjected to exchangeable-cation analysis (table 5). Because soils, glacial deposits, and Sentinel Butte sands in the study area have similar clay mineral composition, the exchange potentials were found to be comparable. The clay minerals in the Sentinel Butte sands were deposited in an excessive sodium environment at the margin of a regressive sea (Carlson, 1973, and Rehbein, 1978) and would thus be expected to be predominantiy sodium in character. However, the amount of natural exchangeable sodium in this core decreased sharply up-core, and calcium and magnesium became the dominant exchangeable cations above 110 feet.

Numerous investigators (Renick, 1925; Tettenhorst, 1962; and Mackenzie, 1963) have demonstrated the preference of chargedeficient clays for divalent over univalent cations. Laboratory 
TABLE 5.--Exchangeable cation analyses of core 77-103

\begin{tabular}{|c|c|c|c|c|c|c|c|c|c|c|c|c|c|}
\hline \multirow[b]{2}{*}{$\begin{array}{l}\text { Sample } \\
\text { depth } \\
\text { (feet) }\end{array}$} & \multicolumn{12}{|c|}{ Milliequivalents per 100 grams } & \multirow{2}{*}{$\begin{array}{c}\begin{array}{c}\text { Percent } \\
\text { total } \\
\text { exchangeable } \\
\text { species }\end{array} \\
\begin{array}{c}\text { Percent sodium } \\
\left(\mathrm{Na}^{+}\right)\end{array}\end{array}$} \\
\hline & $\begin{array}{l}\text { Cation } \\
\text { exchange } \\
\text { capacity }\end{array}$ & $\begin{array}{l}\text { Calcium } \\
\left(\mathrm{Ca}^{2+}\right)\end{array}$ & $\begin{array}{l}\text { Magnesium } \\
\left(\mathrm{Mg}^{2+}\right)\end{array}$ & $\begin{array}{l}\text { Sodium } \\
\qquad\left(\mathrm{Na}^{+}\right)\end{array}$ & $\begin{array}{c}\text { Potassium } \\
\qquad\left(\mathrm{K}^{+}\right)\end{array}$ & $\begin{array}{l}\text { Strontium } \\
\left(\mathrm{Sr}^{2+}\right)\end{array}$ & $\begin{array}{l}\text { Lithium } \\
\left(\mathrm{Li}^{+}\right)\end{array}$ & $\begin{array}{c}\text { Zinc } \\
\left(2 n^{2+}\right)\end{array}$ & $\begin{array}{l}\text { Molybdenum } \\
\left(\mathrm{Mo}^{3+}\right)\end{array}$ & $\begin{array}{l}\text { Barium } \\
\left(\mathrm{Ba}^{2+}\right)\end{array}$ & $\begin{array}{c}\text { Iron } \\
\left(\mathrm{Fe}^{3+}\right)\end{array}$ & $\begin{array}{l}\text { Manganese } \\
\left(\mathrm{Mn}^{3+}\right)\end{array}$ & \\
\hline $\begin{array}{l}12 \\
25 \\
36 \\
50 \\
67\end{array}$ & $\begin{array}{l}20 \\
35 \\
18 \\
15 \\
24\end{array}$ & $\begin{array}{c}15 \\
27 \\
9.5 \\
7.3 \\
15\end{array}$ & $\begin{array}{l}3.0 \\
6.0 \\
7.2 \\
7.0 \\
6.6\end{array}$ & $\begin{array}{r}0.35 \\
.41 \\
.33 \\
.55 \\
.60\end{array}$ & $\begin{array}{r}0.33 \\
.87 \\
.23 \\
.31 \\
.26\end{array}$ & $\begin{array}{r}0.03 \\
.09 \\
.06 \\
.06 \\
.07\end{array}$ & $\begin{array}{l}0 \\
0 \\
0 \\
0 \\
0\end{array}$ & $\begin{array}{c}0.002 \\
.002 \\
0 \\
.015 \\
.01\end{array}$ & $\begin{array}{l}0 \\
0 \\
0 \\
0 \\
0\end{array}$ & $\begin{array}{r}0.03 \\
.01 \\
.01 \\
.05 \\
.01\end{array}$ & $\begin{array}{r}0.001 \\
.001 \\
.001 \\
.001 \\
0\end{array}$ & $\begin{array}{l}0 \\
.05 \\
.01 \\
0 \quad .24\end{array}$ & $\begin{array}{l}2 \\
1 \\
2 \\
4 \\
3\end{array}$ \\
\hline $\begin{array}{r}87 \\
109 \\
148 \\
158 \\
168\end{array}$ & $\begin{array}{l}13 \\
15 \\
30 \\
25 \\
22\end{array}$ & $\begin{array}{c}6.2 \\
8.2 \\
15 \\
11 \\
7.5\end{array}$ & $\begin{array}{l}6.1 \\
5.7 \\
9.3 \\
7.0 \\
6.6\end{array}$ & $\begin{array}{c}.54 \\
.10 \\
4.0 \\
6.0 \\
7.0\end{array}$ & $\begin{array}{l}.20 \\
.17 \\
.90 \\
.60 \\
.77\end{array}$ & $\begin{array}{l}.05 \\
.05 \\
.20 \\
.20 \\
.15\end{array}$ & $\begin{array}{l}0 \\
0 \\
0 \\
0 \\
0\end{array}$ & $\begin{array}{l}.01 \\
.01 \\
.01 \\
.01 \\
.01\end{array}$ & $\begin{array}{l}0 \\
0 \\
0 \\
0 \\
0\end{array}$ & $\begin{array}{l}0 \\
.04 \\
.03 \\
.01 \\
.01\end{array}$ & $\begin{array}{l}.01 \\
0 \\
0 \\
0 \\
0\end{array}$ & $\begin{array}{l}.01 \\
.01 \\
.36 \\
.03 \\
.40\end{array}$ & $\begin{array}{r}4 \\
1 \\
14 \\
24 \\
32\end{array}$ \\
\hline $\begin{array}{l}185 \\
197 \\
209 \\
223 \\
233\end{array}$ & $\begin{array}{l}27 \\
30 \\
32 \\
29 \\
25\end{array}$ & $\begin{array}{c}12 \\
14 \\
15 \\
13 \\
6.8\end{array}$ & $\begin{array}{l}4.9 \\
6.2 \\
5.5 \\
4.9 \\
6.0\end{array}$ & $\begin{array}{r}8.0 \\
8.0 \\
9.0 \\
9.0 \\
11\end{array}$ & $\begin{array}{c}1.1 \\
.50 \\
.84 \\
.90 \\
1.0\end{array}$ & $\begin{array}{l}.15 \\
.16 \\
.15 \\
.13 \\
.20\end{array}$ & $\begin{array}{l}0 \\
0 \\
0 \\
0 \\
0\end{array}$ & $\begin{array}{l}.005 \\
.005 \\
.005 \\
.01 \\
.005\end{array}$ & $\begin{array}{l}0 \\
0 \\
0 \\
0 \\
0\end{array}$ & $\begin{array}{l}.03 \\
.03 \\
.04 \\
.03 \\
.03\end{array}$ & $\begin{array}{l}0 \\
0 \\
0 \\
0 \\
0\end{array}$ & $\begin{array}{l}.14 \\
.07 \\
.23 \\
.16 \\
.08\end{array}$ & $\begin{array}{l}31 \\
27 \\
30 \\
32 \\
49\end{array}$ \\
\hline $\begin{array}{l}243 \\
266\end{array}$ & $\begin{array}{l}40 \\
30\end{array}$ & $\begin{array}{r}13 \\
8\end{array}$ & $\begin{array}{l}10 \\
8.6\end{array}$ & $\begin{array}{l}12 \\
11\end{array}$ & $\begin{array}{r}.73 \\
1.30\end{array}$ & $\begin{array}{l}.33 \\
.20\end{array}$ & $\begin{array}{l}0 \\
0\end{array}$ & $\begin{array}{l}.012 \\
.10\end{array}$ & $\begin{array}{l}0 \\
0\end{array}$ & $\begin{array}{l}.02 \\
.01\end{array}$ & $\begin{array}{l}0 \\
0\end{array}$ & $\begin{array}{l}.03 \\
.001\end{array}$ & $\begin{array}{l}33 \\
38\end{array}$ \\
\hline
\end{tabular}


determinations of the cation-exchange characteristics and calculations of selectivity coefficients on samples from the Gascoyne Mine area in southwestern North Dakota showed that the clay minerals and lignitic material comprising the Tongue River Member specifically have large cation-exchange selectivity for calcium relative to sodium. Thus, if calcium-bearing water contacted the sodium-rich clays of the Sentinel Butte Member, cation exchange releasing sodium is likely.

Previously discussed leaching experiments on the Sentinel Butte cores demonstrated the presence of calcium donors (carbonates and lesser amounts of gypsum), that also decrease with depth. Dissolution of such soluble calcium-bearing minerals by downward percolating calcium sulfate-bicarbonate waters could supply calcium for exchange for sodium on clay minerals deeper in the formation according to the following reaction:

$$
\mathrm{Ca}^{2+}+2 \mathrm{Na}(\mathrm{Clay}) \rightarrow 2 \mathrm{Na}^{+}+\mathrm{Ca}(\mathrm{Clay})
$$

This reaction would result in waters enriched in sodium, sulfate, and bicarbonate with tendencies toward an alkaline pH. Removal of calcium from solution would catalyze further dissolution of calcite and gypsum. Thus, as surficial clays become saturated with calcium, cation-exchange processes would occur progressively deeper in the section as long as soluble calcium was still available in agreement with the observed gradation of decreasing exchanged calcium with depth (table 5).

A competing process also may be producing new sodic clays, but at a much slower rate. Sodic plagioclase weathers to a sodium-rich smectite under mildly acidic conditions and in the presence of excess water (Winchell, 1951):

$$
\begin{aligned}
& 7 \mathrm{NaAlSi}{ }_{3} \mathrm{O}_{8}(\mathrm{~s})+6 \mathrm{H}^{+}+2 \mathrm{OH}_{2} \mathrm{O} \\
\longrightarrow & 5 \mathrm{Na}^{+}+10 \mathrm{H}_{4} \mathrm{SiO}_{4}+3 \mathrm{Na}_{0} .33 \mathrm{Al}_{2} .33^{\mathrm{Si}_{3}} 3.670{ }_{10}(\mathrm{OH})_{2}(\mathrm{~s}) .
\end{aligned}
$$

However, in the absence of acidic conditions, albite preferentially weathers to kaolinite:

$2 \mathrm{NaAlSi}{ }_{3} \mathrm{O}_{8}(\mathrm{~s})+11 \mathrm{H}_{2} \mathrm{O}$

$$
\rightarrow 2 \mathrm{Na}^{+}+2 \mathrm{OH}^{-}+4 \mathrm{H}_{4} \mathrm{SiO}_{4}+\mathrm{Al}_{2} \mathrm{Si}_{2} \mathrm{O}_{5}(\mathrm{OH})_{4} \text {. }
$$

Both reactions release considerable amounts of sodium into the water. Busenberg (1975) has demonstrated that under nonacid con- 
ditions reaction (5) may still be the intermediary for continued hydration to smectite, accompanied by sodium uptake. However, if weathering of albite is extensive, sodium release can inhibit divalent cation-exchange processes. Petrographic analysis of this core shows the albite present has been weathered by etching, probably along dislocation outcrops, not by surface alteration. Notably, the only sample to contain appreciable kaolinite (148-149 feet; table 3) also contained anomalously small amounts of albite. As sodic smectites also are unusually abundant in this sample, a coupled weathering reaction may well be producing new sodic smectite, creating new potential exchange sites for divalent cations.

\section{Basal Sentinel Butte Aquifer}

Four water samples collected from wells tapping the aquifer in the basal sentinel Butte sandstone were analyzed for dissolved ionic species (table 6). Sodium plus potassium constituted more than 80 percent of the cations. Sodium concentrations ranged from 390 to $870 \mathrm{mg} / \mathrm{L}$, whereas calcium and magnesium concentrations were less than $8 \mathrm{mg} / \mathrm{L}$ in all samples. Bicarbonate and carbonate constituted from 68 to 84 percent of the anions, and sulfate ranged from 14 to 32 percent. Chloride concentrations ranged from 3.0 to $250 \mathrm{mg} / \mathrm{L}$. Concentrations of trace metals, including iron and manganese, were minimal in all samples analyzed. Dissolved-solids concentrations ranged from 1,010 to $2,150 \mathrm{mg} / \mathrm{L}$.

Calculation of mineral saturation coefficients for two of these samples (table 7) indicates the ground water in this zone is near saturation to very slightly undersaturated with respect to calcite and dolomite and significantly undersaturated with respect to gypsum and fluorite. The aquifer water is siightly saturated with quartz, but undersaturated with respect to other silica polymorphs. The minimal degree of saturation of this water with respect to carbonate and silica minerals indicates that the probability of precipitation of chemical cements in the basal Sentinel Butte sandstone is small. Petrographic analysis of the basal Sentinel Butte sandstone shows the lack of precipitate. Cementation is relatively rare and is dominated by quartz overgrowths. Where detected, secondary calcite appeared to have been replaced by recent silica.

Petrographic examination of the sediments throughout the Sentinel Butte Member indicates calcite and dolomite occur as void fillings and cement between grains in the sandstone and silty claystone units. The sandstone penetrated at 77 feet in core 77-103 is completely cemented with calcite. Elsewhere, it appears that calcite is being selectively replaced by microcrystalline silica polymorphs, consistent with the results 


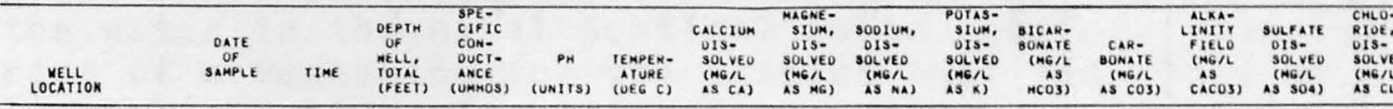
Basal Sentinel Butte aquifer

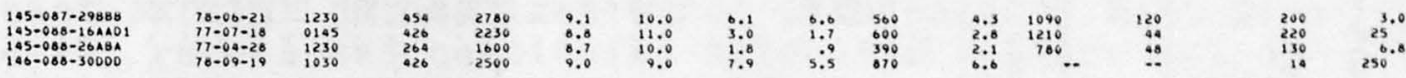

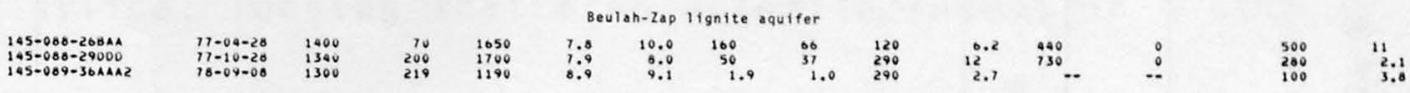

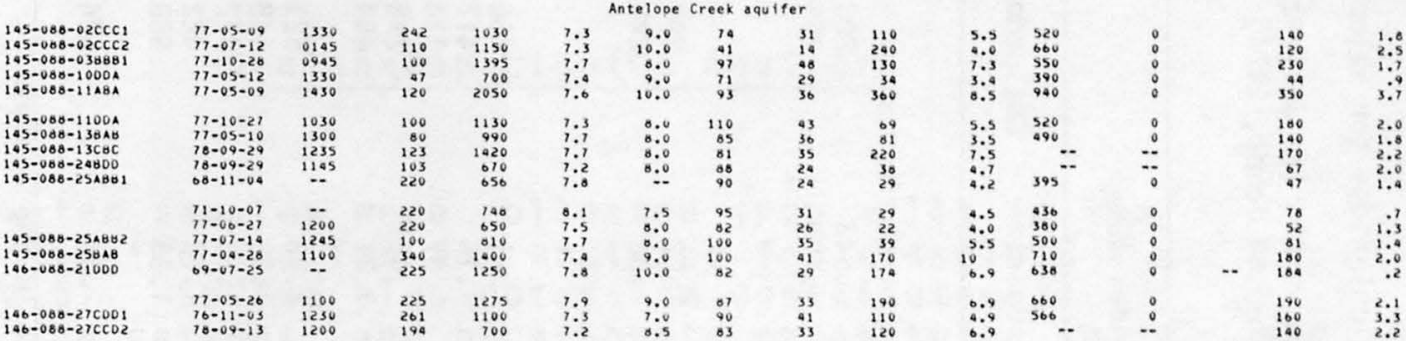

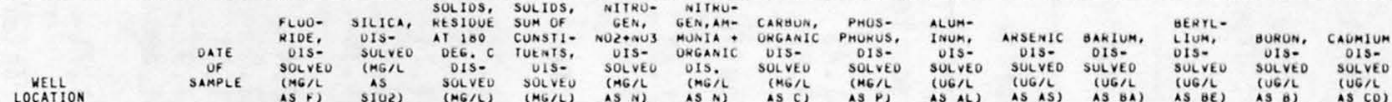

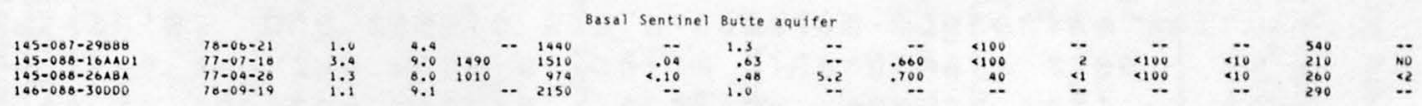

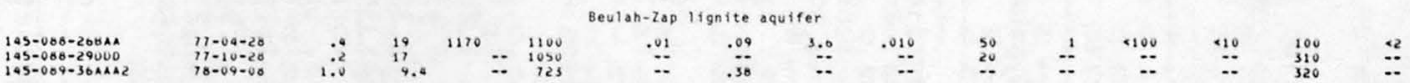

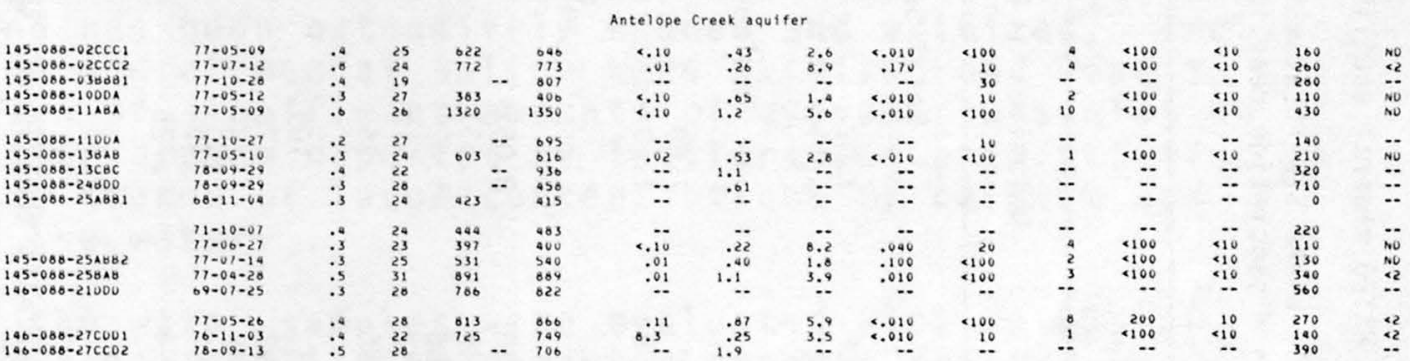

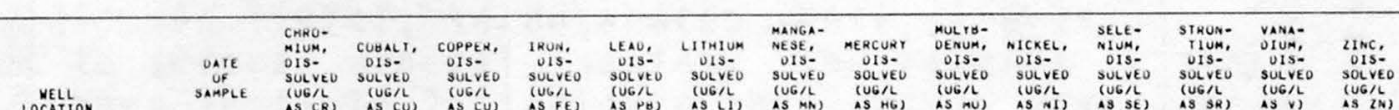

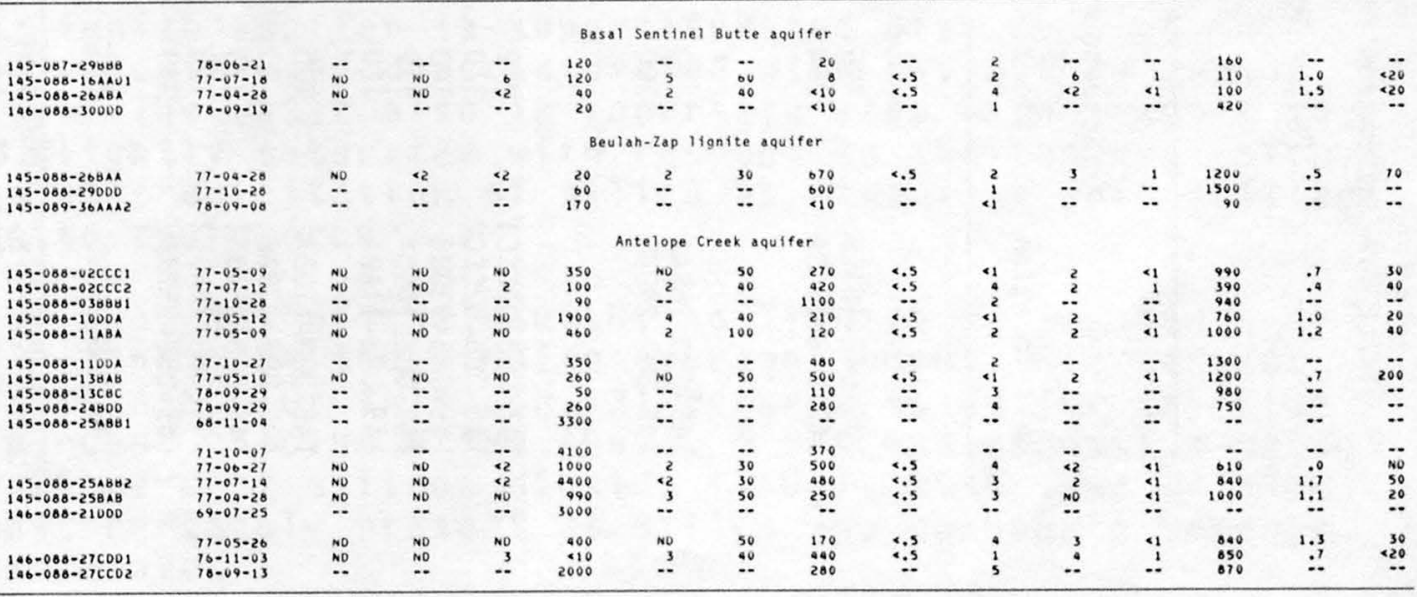


TABLE 7.--Saturation indices of WATEQ mineral equilibrium and solubility calculations for selected ground-water samples

$\left[S I_{M}=\log (I A P / K)\right.$, where $S I_{M}=$ saturation index for mineral $M$, IAP = ion activity product, and $K=$ dissociation reaction constant 1/; Truesdale and Jones, 1974]

\begin{tabular}{|c|c|c|c|c|c|c|c|c|c|}
\hline \multirow[b]{2}{*}{ Well location } & \multirow{2}{*}{$\begin{array}{c}\text { Screened } \\
\text { depth } \\
\text { (feet) }\end{array}$} & \multicolumn{8}{|c|}{ Saturation index (SIM) } \\
\hline & & Calcite & Dolomite & Gypsum & Fluorite & Quartz & Chalcedony & glass & Magnesite \\
\hline \multicolumn{10}{|c|}{ Basal Sentinel Butte aquifer } \\
\hline $\begin{array}{l}145-088-16 A A D \\
145-088-26 A B A\end{array}$ & $\begin{array}{l}426 \\
264\end{array}$ & $\begin{array}{r}.588 \\
-.021\end{array}$ & $\begin{array}{l}1.02 \\
-.293\end{array}$ & $\begin{array}{l}-3.68 \\
-4.09\end{array}$ & $\begin{array}{l}-1.43 \\
-2.67\end{array}$ & $\begin{array}{l}.543 \\
.493\end{array}$ & $\begin{array}{l}-.203 \\
-.255\end{array}$ & $\begin{array}{l}-.925 \\
-.953\end{array}$ & $\begin{array}{r}.035 \\
-.675\end{array}$ \\
\hline \multicolumn{10}{|c|}{ Beulah-Zap lignite aquifer } \\
\hline $\begin{array}{l}145-088-26 B A A \\
145-088-29 D D D\end{array}$ & $\begin{array}{r}70 \\
200\end{array}$ & $\begin{array}{l}1.02 \\
.878\end{array}$ & $\begin{array}{l}1.69 \\
1.69\end{array}$ & $\begin{array}{l}-.845 \\
-1.77\end{array}$ & $\begin{array}{l}-1.57 \\
-2.94\end{array}$ & $\begin{array}{l}1.02 \\
1.00\end{array}$ & $\begin{array}{l}.298 \\
.240\end{array}$ & $\begin{array}{l}-.411 \\
-.460\end{array}$ & $\begin{array}{l}.278 \\
.422\end{array}$ \\
\hline \multicolumn{10}{|c|}{ Antelope Creek aquifer } \\
\hline $\begin{array}{l}145-088-02 C C C 1 \\
145-088-02 C C C 2 \\
145-088-03 B B B \\
145-088-10 D D A \\
145-088-11 A B A\end{array}$ & $\begin{array}{l}242 \\
110 \\
100 \\
117 \\
120\end{array}$ & $\begin{array}{r}0.220 \\
-.089 \\
.886 \\
.267 \\
.965\end{array}$ & $\begin{array}{l}0.057 \\
-.657 \\
1.47 \\
-.572 \\
.160\end{array}$ & $\begin{array}{l}-1.77 \\
-2.26 \\
-1.43 \\
-2.38 \\
-1.35\end{array}$ & $\begin{array}{l}-1.77 \\
-1.36 \\
-1.71 \\
-2.02 \\
-1.36\end{array}$ & $\begin{array}{l}1.21 \\
1.16 \\
1.07 \\
.451 \\
1.21\end{array}$ & $\begin{array}{r}0.456 \\
.417 \\
.314 \\
-.298 \\
.464\end{array}$ & $\begin{array}{r}-0.246 \\
-.283 \\
-.387 \\
-1.02 \\
-.237\end{array}$ & $\begin{array}{r}-0.573 \\
-.984 \\
.191 \\
-1.26 \\
.165\end{array}$ \\
\hline $\begin{array}{l}145-088-11 D D A \\
145-088-13 B A B \\
145-088-25 A B B 1 \\
145-088-25 A B B 2 \\
145-088-25 B A B\end{array}$ & $\begin{array}{r}100 \\
80 \\
220 \\
100 \\
340\end{array}$ & $\begin{array}{l}.311 \\
.693 \\
.842 \\
.659 \\
.564\end{array}$ & $\begin{array}{l}.169 \\
.978 \\
1.16 \\
.730 \\
.725\end{array}$ & $\begin{array}{l}-1.49 \\
-1.73 \\
-1.91 \\
-2.23 \\
-1.58\end{array}$ & $\begin{array}{l}-2.41 \\
-2.06 \\
-1.91 \\
-1.97 \\
-1.43\end{array}$ & $\begin{array}{l}1.28 \\
1.20 \\
1.23 \\
1.18 \\
1.33\end{array}$ & $\begin{array}{l}.521 \\
.448 \\
.472 \\
.422 \\
.588\end{array}$ & $\begin{array}{l}-.178 \\
-.255 \\
-.229 \\
-.283 \\
-.118\end{array}$ & $\begin{array}{l}-.528 \\
-.103 \\
-.076 \\
-.323 \\
-.237\end{array}$ \\
\hline $146-088-21000$ & 225 & 1.12 & 1.79 & -1.62 & -1.71 & 1.27 & .524 & -.178 & .278 \\
\hline
\end{tabular}

1/ Where SIM is positive, WATEQ indicates the mineral species is supersaturated in the anaTyzed

water; where SIM is negative, the mineral species is undersaturated in the analyzed water. The significance of differing magnitudes of SIM varies depending upon the mineral species being considered, largely as a result of kinetic considerations. The significance of the numeric values reported above is qualitatively interpreted in the text. 
obtained using WATEQ. Altering volcanic glass abundant in some beds within the Sentinel Butte could be the principal supply of silica to the water in the basal sentinel Butte aquifer. The apparent order of cementation for the samples examined could be: (1) An early precipitation of calcite as cement and void fill, (2) subsequent partial dolomitization of carbonate by magnesium waters, and (3) recent and continuing selective replacement of calcite by silica, leaving scattered dolomite rhombs in a silica matrix.

\section{Beulah-Zap Lignite Aquifer}

Three water samples were collected from wells in the Beulah-Zap lignite aquifer and analyzed for dissolved ionic species (table 6). Sodium plus potassium constituted 29, 70 , and 99 percent of the cations, and bicarbonate constituted 40, 67, and 82 percent of the anions present. Dissolved solids were 1,170, 1,050 , and $723 \mathrm{mg} / \mathrm{L}$ (mi11igrams per 1iter).

Composition of the water in the Beulah-zap lignite appears to be quite variable. One sample was a calcium-magnesium sulfatebicarbonate type and two were a sodium bicarbonate type. Well 145-088-26BAA is located within a shallow, eroded part of the Beulah-Zap lignite and produced water of a calcium-magnesium sulfate type. Near the well, another small bed of lignite subcrops and has been extensively eroded and oxidized. Included iron sulfide and elemental sulfur were oxidized and lead to the precipitation of significant amounts of gypsum. Dissolution of this and other gypsum deposits by infiltrating precipitation is the probable source of large concentrations of calcium and sulfate in the water.

Two of the water samples were evaluated with WATEQ, a mineral-solution equilibrium computer program devised by Truesdale and Jones (1974), to determine their saturation with respect to several mineral species. The results of the evaluation, shown in table 7, indicate that ground water in the Beulah-Zap lignite aquifer is supersaturated with respect to calcite and dolomite and undersaturated with respect to gypsum and fluorite. The water also is supersaturated with respect to quartz and sightly saturated with respect to chalcedony, which indicates that precipitation of silica as cement or void fillings in the lignite could occur.

Chemical analyses of the Beulah-Zap lignite by Swanson and others (1974) indicate the lignite averages about 10.2 percent noncombustible ash. Of this ash, 21 percent is sulfur trioxide $\left(\mathrm{SO}_{3}\right), 18$ percent calcium oxide $(\mathrm{CaO}), 5$ percent magnesium oxide (MgO), and 26 percent silicon dioxide ( $\left.\mathrm{SiO}_{2}\right)$, with some of the latter almost certainly present as silica and carbonate cements as indicated above. 
The leachate of average ash from the Beulah-Zap lignite contained $925 \mathrm{mg} / \mathrm{L}$ barium, $115 \mathrm{mg} / \mathrm{L}$ boron, $7.1 \mathrm{mg} / \mathrm{L}$ copper, 20.0 $\mathrm{mg} / \mathrm{L}$ fluoride, $4 \mathrm{mg} / \mathrm{L}$ lithium, $56 \mathrm{mg} / \mathrm{L}$ manganese, $2 \mathrm{mg} / \mathrm{L}$ molybdenum, $812 \mathrm{mg} / \mathrm{L}$ strontium, and $8.6 \mathrm{mg} / \mathrm{L}$ zinc. Other trace metals were found only in minimal concentrations, probably due to the relative insolubility of these trace metals in alkaline waters. Leaching of trace elements from the Beulah-Zap lignite may account for some of the large trace-element concentrations determined in water from the Beulah-Zap and basal Sentinel Butte aquifers.

The barium concentration appears large in the lignite based on the one sample where it was determined. As barium commonly replaces calcium in marine gypsum (Stewart, 1963), the secondary gypsum may be the source of this barium. The barium was perhaps originally associated with marine clays in the lignite.

\section{Antelope Creek Aquifer}

Fifteen water samples collected from various zones in the Antelope Creek aquifer were analyzed to determine their chemical composition (table 6). Water composition within the Antelope creek aquifer was found to be variable; water types ranged from calcium-magnesium bicarbonate to sodium bicarbonate.

Sodium plus potassium comprised from 16 to 78 percent of the cations present, and bicarbonate and carbonate from 62 to 84 percent of the anions. Dissolved-solids concentratons ranged from 383 to $1,320 \mathrm{mg} / \mathrm{L}$. Ground-water $\mathrm{pH}$ remained relatively constant, ranging from 7.20 to 7.90 .

The WATEQ (table 7) evaluation of water samples from the Antelope Creek aquifer indicates most samples are near saturation with respect to calcite and dolomite, supersaturated with respect to quartz and chalcedony, and greatly undersaturated with respect to gypsum and fluorite. Active precipitation of chemical cements in areas of slow water movement in the aquifer could be expected, and precipitation of silica is predominant over carbonate.

Although unreported in table 7 , WATEQ also indicates the Antelope Creek waters are saturated with respect to all clay minerals detected. Thus, if alterable parent material is present, clay mineral formation would be likely to occur. Examination of core samples from the study area indicates the porosity decrease with depth is due largely to a general increase in the abundance of matrix clays in the basal Sentinel Butte sandstone. At least some of this clay matrix increase might reflect diagenetic formation of clays. 
Water chemistry in the upper unit of the Antelope Creek aquifer appears to be controlled primarily by infiltration of precipitation through soils and rocks of varying soluble mineral compositions and cation-exchange potentials. For example, wells 145-088-11ABA and 145-088-03BBB are 1ocated near subcrops of extensively eroded and oxidized Beulah-Zap lignite. Dissolution of secondary gypsum produced by oxidation of pyrite in the lignite probably explains the large sulfate concentrations in water from these wells. In fact, sulfate concentrations in water from the upper unit of the Antelope Creek aquifer appear to decrease proportionally with distance from lignite outcrops or subcrops. This decrease is a result of areal recharge over the aquifer and downward leakage into the lower aquifers. Similarly, the large concentration of bicarbonate in water from well 145-088-11ABA may reflect the effects of dissolution of calcite near the surface by infiltrating precipitation, as water from the well currently is more saturated with respect to calcite than water from other Antelope Creek wells of similar depth.

The effects of leaching processes on water chemistry in the aquifer appear to be modified by other processes. Dissolution of gypsum also releases calcium ions into solution. However, in the Antelope Creek aquifer, calcium and magnesium concentrations decrease with depth and sodium concentrations increase, probably reflecting exchange of divalent cations for sodium on sodic smectites as discussed previously. Weathering of albite to smectite also could contribute some sodium to solution if acidic conditions locally prevail near the lignite outcrops. As WATEQ indicates that silica, which would simultaneously be released by this weathering reaction, is supersaturated in these waters, precipitation of silica cement would decrease any increase in dissolved silica, which might be expected as confirmation of the effects of plagioclase weathering.

The dominant chemical controls on water in the Antelope Creek aquifer also vary with hydrologic regime. Wells 145088-13BAB, 145-088-25ABB1, and 145-088-25ABB2 are 10cated in the center of the Antelope Creek aquifer. Analyses of ground-water samples from this area indicates little effect due to weathering of lignite along the east edge of the aquifer. North of well 145-088-13ABA, the hydraulic gradient is northward. South of well 145-088-13BAB, the hydraulic gradient is southward. Ground waters north of the divide are enriched in sodium, sulfate, and dissolved solids; reflecting the effect of local lignite outcrops. Ground waters south of the divide contain much less sulfate and smaller sodium/calcium ratios. These waters are alkaline and calcium-magnesium bicarbonate in type, which indicates that carbonate is the dominant soluble mineral available for leaching by infiltrating precipitation. Analyses of samples from three wells screened at different depths in section 25 indicate that the concentration of sodium increases with depth and the concentration of calcium decreases, indicating that the 
exchange of divalent cations for univalent cations on clays is an effective means of altering ground-water chemistry in the area.

\section{SURFACE-WATER HYDROLOGY}

The study area is drained by West Branch Antelope Creek (herein considered a third-order stream) which is a tributary of Antelope Creek (a fourth-order stream). West Branch Antelope Creek enters Antelope Creek about 9 river miles upstream from the Antelope Creek confluence with the Knife River. The downstream $1 \mathrm{imit}$ of the study area is in the SW $1 / 4 \mathrm{SE} 1 / 4 \mathrm{SE} 1 / 4 \mathrm{sec} .32$, T. 145 N., R. 87 W. (fig. 20), where the altitude is about 1,860 feet. The altitude at the divide near the headwaters of the longest water course is about 2,300 feet. With a total length of 15.8 river miles, the mean slope of the stream is about $27.8 \mathrm{ft} / \mathrm{mi}$. The drainage generally is well developed, although there are isolated areas of shallow prairie potholes or depressions and scattered manmade stock-watering ponds. West Branch Antelope Creek is an ephemeral stream with most of the flow usually occurring during the spring snowmelt period.

From river mile 0 at the southeastern end of the study area to river mile 5.2, West Branch Antelope Creek flows through a cultivated valley that has an average width of 0.7 mile and a mean channel slope of about $15 \mathrm{ft} / \mathrm{mi}$. From river mile 5.2 to 10.4 the valley is much narrower and channel slope is $39 \mathrm{ft} / \mathrm{mi}$. The surrounding land is used mostly for grazing. Upstream from river mile 10.4, the valley disappears and only a small channel remains. The land in this area is mostly cultivated.

At river mile 4.5 an unnamed second-order tributary enters West Branch Antelope Creek. This unnamed tributary drains the north-central and northeastern parts of the study area. The downstream 3.4 river miles of this tributary occur in a northward continuation of the valley of West Branch Antelope Creek. The valley is extremely flat and there is no significantly defined channe1. Runoff spreads out and a significant amount of water is lost through infiltration.

Assessment of the potential impacts of mining on the surfacewater hydrology necessitates the defining of peak flows, flow regimes, volumes, water quality, sediment yields, soil-water relationships, and ground-water recharge and discharge before, during, and after mining. To adequately evaluate present hydrologic conditions and the probable changes that may occur as a result of mining, the temporal and spatial variations of these factors is believed best defined through the use of a hydrologic model. To develop a model simulating this regime, hydrologic, meteorologic, and basin-characteristic data are required. The actual modeling was beyond the scope of this project and is being 


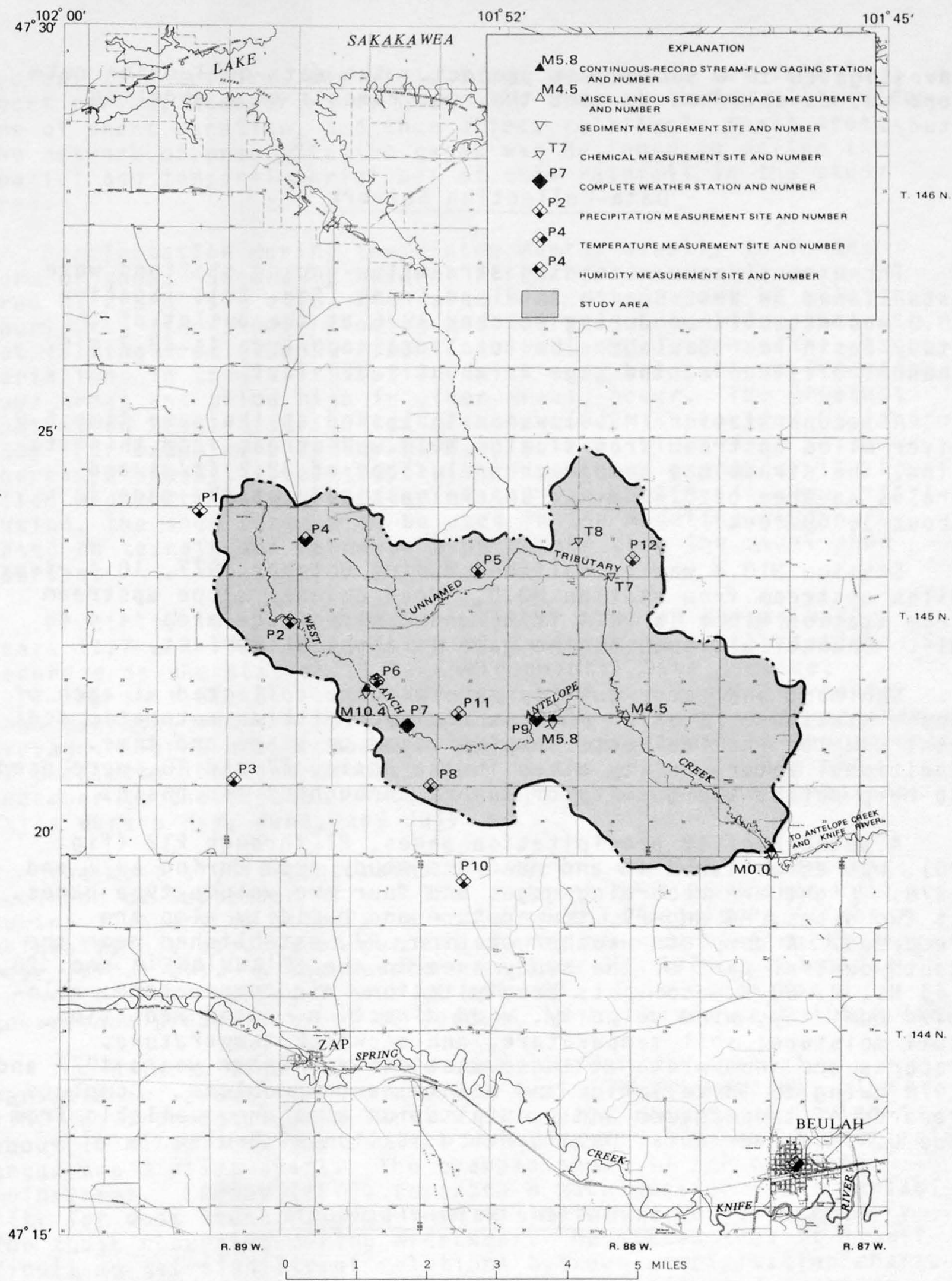

FIGURE 20.-Location of data-collection sites, excluding wells, in the study area and vicinity. 
investigated in a subsequent project. The data-collection network was established to meet the requirements of a modeling study.

\section{Data-Collection Network}

Three continuous-recording streamflow-gaging stations were established on West Branch Antelope Creek (fig. 20). Station MO. 0 was established during 0ctober 1976 at the outlet of the study basin near Beulah. The total drainage area is $28.3 \mathrm{mi}^{2}$. Channel altitude at the gage is about 1,860 feet.

A second station (M5.8) was established at the same time 5.8 river miles upstream from station M0.0. Upstream from this station, the stream has a mean channel slope of $32.2 \mathrm{ft} / \mathrm{mi}$ and drains an area of $8.46 \mathrm{mi}^{2}$. Channel altitude at the gage is about 1,960 feet.

Station M10.4 was established during 0ctober 1977, 10.4 river miles upstream from station MO.0. Mean channel slope upstream from station Ml0.4 is $22.4 \mathrm{ft} / \mathrm{mi}$ and the drainage area is 4.45 $\mathrm{mi}^{2}$. Channel altitude at the gage is about 2,130 feet.

Sediment and water-quality samples were collected at each of these stations. Station M5.8 is equipped with an automatic sediment sampler that collects samples based on stage and time.

Additional water-quality sites in the basin, T7 and T8, were used to help define the quality of runoff throughout the basin.

A network of 12 precipitation gages, Pl through P12 (fig. 20), was established in and near the study area during 1977 and 1978. Eight are recording gages and four are volume-type gages. At two sites, P4 and P9, temperature and humidity also are recorded. A complete weather station, P7, established near the south-central part of the study area in the SE1/4NW1/4NE1/4 sec. $28, T$. 145 N., R. 88 W. collects precipitation, air temperature, relative humidity, wind velocity, wind direction, solar radiation, soil moisture, soil temperature, and snowpack temperature. Records are incomplete at these stations for water years 1977 and 1978 owing to installation and maintainance problems. Complete records of temperature and precipitation also are available from the U.S. Environmental Data Service station at Beulah.

\section{Snowmelt and Rainfall Runoff}

of the components that comprise climate, precipitation has the greatest effect on the local surface-water hydrology. Most of the precipitation during the summer is from thunderstorms. 
Typical thunderstorms may yield large amounts of rainfall in a short period; however, they generally are only a few miles wide, are of short duration, and thus affect relatively small areas. The network of precipitation gages was designed to define the spatial and temporal variations of this rainfall in the study area.

Precipitation during the winter months usually is in the form of snow. Generally several blizzards occur each year. A true blizzard is a cold, high wind (exceeding about 15 miles per hour) with fine snow. Blowing and drifting snow (snow that is not falling from clouds) also is quite common. Therefore, large variations in snow distribution, with snow being blown free from some areas and piled high in other areas, occur. The greatest control on areal distribution of snow cover is provided by land use. For example, a fallow hilltop will be blown free of snow whereas a brushy, steep slope with a southern exposure will be piled high with snow. Because of the variability in snow distribution, the snow surveys to be used in the modeling study are based on terrain and land-use type rather than the usual snow courses.

Precipitation at the Beulah weather station during water years 1977 and 1978 is compared to the average precipitation recorded at the station (U.S. Environmental Data Service, 1977-79) in table 8. The 1977 water year was 9 percent wetter than average, and the 1978 water year was 10 percent dryer than average. There are pronounced seasonal variations in the amount of precipitation that occurs; June is the wettest month and December is the dryest. About 50 percent of the precipitation falls during May, June, and July.

The most significant rainstorm during the 1978 water year occurred on September 11 and 12 . A total of 1.95 inches fell during 10 hours at site P9, a storm of this magnitude (12-hour rainfal1) has about a 35 percent chance of occurring during any year (fig. 21). A thunderstorm on June 29, 1978, produced 1.05 inches of rain during 1 hour at site P9. This storm has a recurrence probability of 58 percent in any given year (fig. 21).

The data in figure 22 give some idea of the spatial variation of precipitation amounts during thunderstorms. The U.S. Environmental Data Service rain gage located at Beulah is about 10 miles from the project rain gages. The two project rain gages are 3 miles apart. The example shown is for moderate rainstorms. Crosby (1974) reported a much greater areal variability for most thunderstorms than is indicated here, especially for those occurring during midsummer. He stated that it is difficult to get significant relations between precipitation characteristics such as total precipitation, intensity and duration, and peak discharge because of this areal variability. 
TABLE 8.--Monthly, annual, and average precipitation for water years 1977-78 at Beulah (Data from U.S. Environmental Data Service, 1973, 1977-79)

\section{Precipitation, in inches}

Month Oct. Nov. Dec. Jan. Feb. Mar. Apr. May June July Aug. Sept. Total

\section{7}

water

year

$\begin{array}{llllllllllllll}\text { (Oct. 1976- } & 0.82 & 0.44 & 0.47 & 0.47 & 0.20 & 0.84 & 0.16 & 3.18 & 3.11 & 2.38 & 1.21 & 5.41 & 18.69\end{array}$

1978

water

year

$.90 \quad .89$

(oct. 1977-

Sept. 1978)

$\begin{array}{lllllllllllllllll}\text { Average } & .66 & .55 & .32 & .47 & .43 & .63 & 1.48 & 2.57 & 3.97 & 2.62 & 2.08 & 1.42 & 17.20\end{array}$




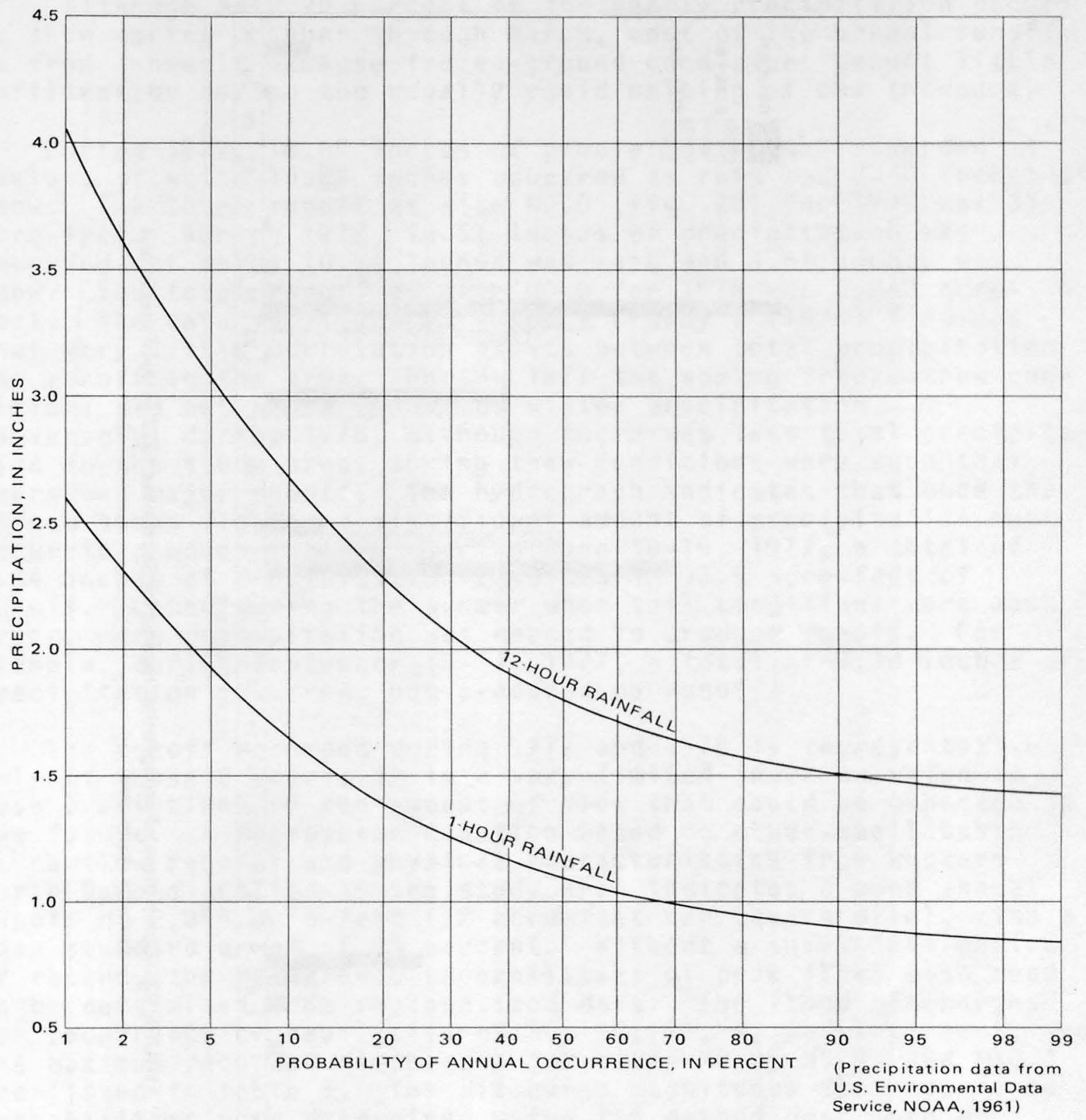

FIGURE 21. -Rainfall frequency curves for the study area.

53 


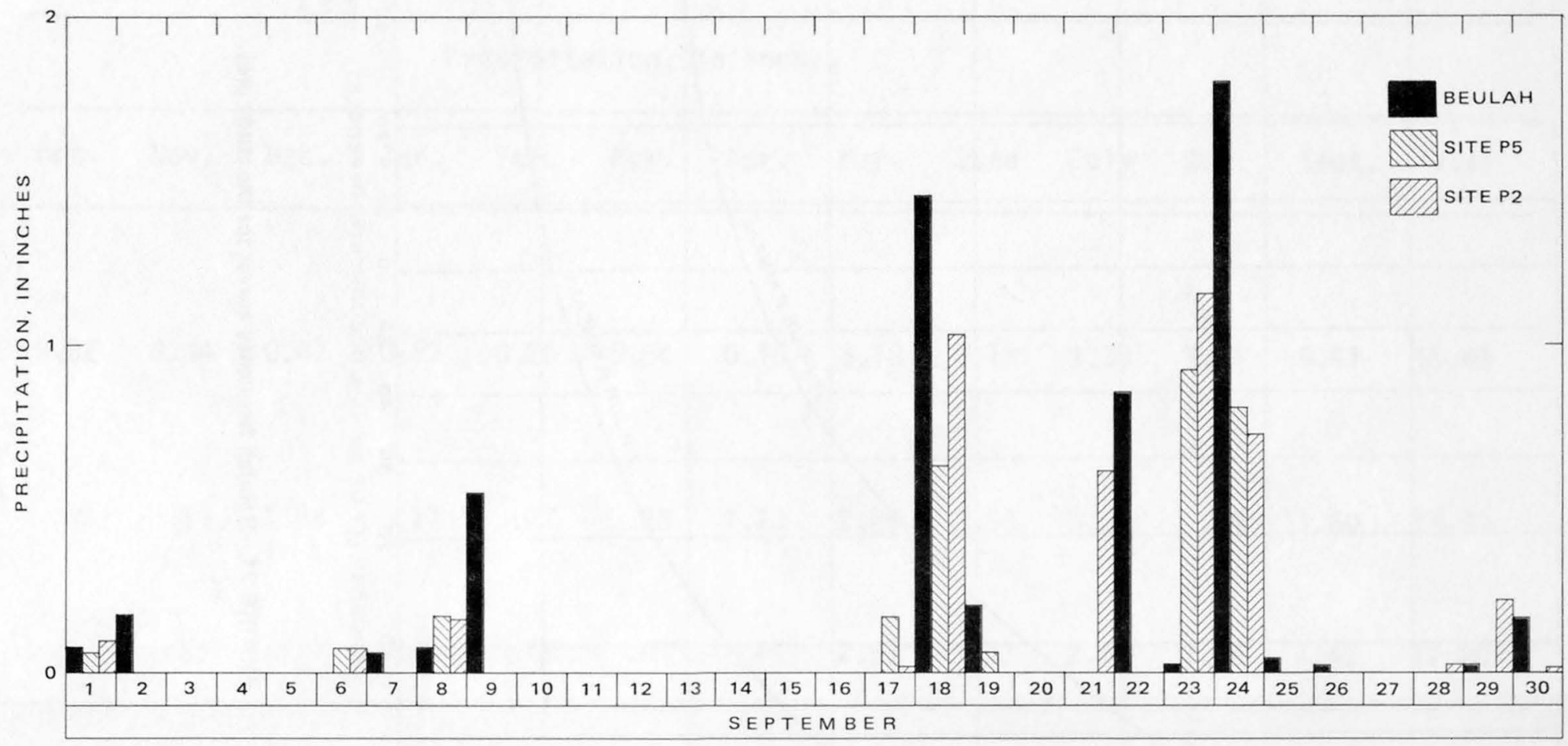

FIGURE 22.-Comparison of precipitation records for September 1977 at three sites in and near the study area. 
Although only 20 percent of the yearly precipitation occurs as snow during october through March, most of the annual runoff is from snowmelt because frozen-ground conditions permit little infiltration during the usually rapid melting of the snowpack.

During $1977,18.69$ inches of precipitation was recorded at Beulah, of which 15.29 inches occurred as rain and 3.40 inches as snow. The total runoff at site M0.0 (fig. 20) for 1977 was 35 acre-feet. During 1978, 15.51 inches of precipitation was recorded, of which 10.84 inches was rain and 4.67 inches was snow. The total runoff at site M0.0 for 1978 was 2,253 acrefeet. The data in figure 23 support Crosby's (1974) findings that very little correlation exists between total precipitation and runoff in the area. During 1977 the spring freeze-thaw conditions did not cause runoff of winter precipitation.

Conversely, during 1978, although there was less total precipitation in the study area, spring thaw conditions were such that there was major runoff. The hydrograph indicates that once the stream stops flowing a significant amount of precipitation must occur to produce runoff. During June 10-16, 1977, a total of 2.34 inches of precipitation resulted in 33.5 acre-feet of runoff. Later during the summer when soil conditions were much dryer, more precipitation was needed to produce runoff. For example, during September 18-24, 1977, a total of 4.30 inches of precipitation occurred, but produced no runoff.

The runoff recorded during 1977 and 1978 is representative only of these 2 years; it is a very limited index on which to base predictions of the amount of flow that could be expected in the future. A regression equation based on other small basin streamflow records and physical characteristics from western North Dakota applied to the study area indicates a mean annual runoff of 2,050 acre-feet (72 acre-feet per square mile), with a mean standard error of 33 percent. Without a sufficient period of record, the recurrence probabilities of peak flows also need to be determined from regionalized data. The flood discharges for recurrence probabilities of $50,20,10,4$, and 2 percent, and the maximum recorded discharges for sites M0.0, M5.8, and M10.4 are 1 isted in table 9. The discharge magnitudes for recurrence probabilities were determined using the method described by Crosby (1975). The tabular data indicate that the peak flow of $296 \mathrm{ft}^{3} / \mathrm{s}$ at site M0.0 for the 1978 water year has a recurrence probability of about 50 percent.

\section{Surface-Water Quality}

Water-quality samples were obtained at seven surface-water sites in the study area. Samples were taken during the rainfallrunoff period of June 15 and 16, 1977, and during the spring snowmelt runoff of March 1978. Analyses of these samples are listed on table 10. 


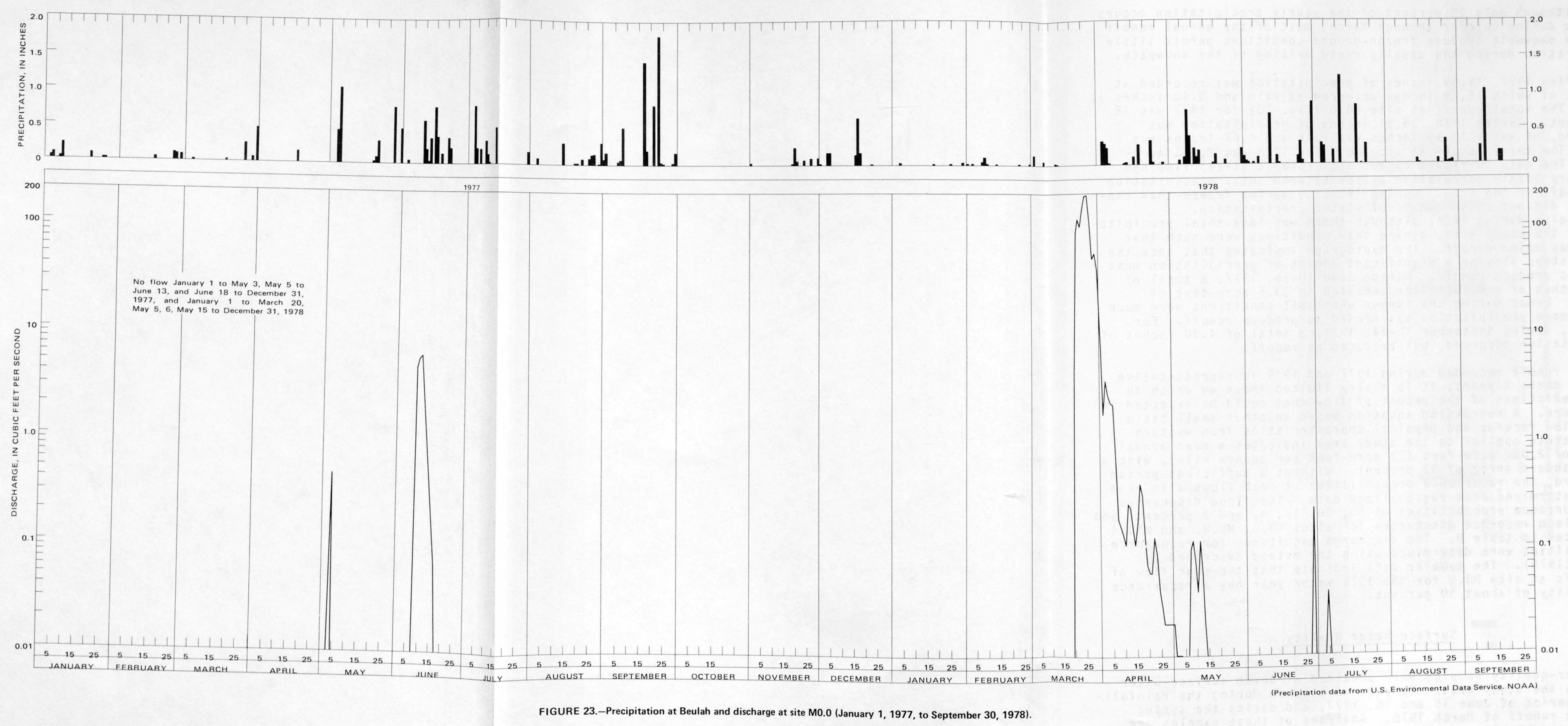


TABLE 9.--Flood discharges at selected recurrence probabilities and maximum recorded annual discharge for water years 1977-78 at sites M0.0, M5.8, and M10.4

Peak discharge (cubic feet per second)

\begin{tabular}{|c|c|c|c|c|c|c|c|}
\hline \multirow[b]{2}{*}{ Site } & \multicolumn{5}{|c|}{ Annual recurrence probabilities (percent) } & \multirow{2}{*}{$\begin{array}{l}1977 \\
\text { maximum }\end{array}$} & \multirow{2}{*}{$\begin{array}{c}1978 \\
\text { maximum }\end{array}$} \\
\hline & 50 & 20 & 10 & 4 & 2 & & \\
\hline M0.0 & 280 & 710 & 1,240 & 1,940 & 2,510 & 37 & 296 \\
\hline M5.8 & 120 & 320 & 510 & 800 & 1,050 & 36 & 155 \\
\hline M10.4 & 71 & 190 & 310 & 480 & 640 & -- & 125 \\
\hline
\end{tabular}


TABLE 10.--Chemical analyses of surface-water samples

(CFS - cubic feet per second; UMHOS = micromhos per centimeter at 25 degrees Celsfus; DEg $C=$ degrees Celsius; $M G / L=m i l l i g r a m s$ per liter; UG/L = micrograms per lifter; ND = not detected)

\begin{tabular}{|c|c|c|c|c|c|c|c|c|c|c|c|c|}
\hline SITE NUMBER & $\begin{array}{c}\text { DATE } \\
\text { OF } \\
\text { SAMPLE }\end{array}$ & TIME & $\begin{array}{l}\text { STKEAM- } \\
\text { FLOM, } \\
\text { INSTAN- } \\
\text { TANEOUS } \\
\text { (CFS) }\end{array}$ & $\begin{array}{l}\text { SPE- } \\
\text { CIFIC } \\
\text { CON- } \\
\text { OUCI- } \\
\text { ANCE } \\
\text { (UMHOS) }\end{array}$ & $\begin{array}{c}P H \\
\text { (UN1TS) }\end{array}$ & $\begin{array}{l}\text { TEMPER- } \\
\text { ATURE } \\
\text { (UEG C) }\end{array}$ & $\begin{array}{l}\text { HARU - } \\
\text { NESS } \\
\text { (MG/L } \\
\text { AS } \\
\text { CACO3) }\end{array}$ & $\begin{array}{l}\text { MARD- } \\
\text { NESS, } \\
\text { NONCAR- } \\
\text { BONATE } \\
\text { (MG/L } \\
\text { CACO3) }\end{array}$ & $\begin{array}{l}\text { CALCIUM } \\
\text { OIS- } \\
\text { SOLVEO } \\
\text { (MG/L } \\
\text { AS CA) }\end{array}$ & $\begin{array}{l}\text { MAGNE- } \\
\text { SIUAA, } \\
\text { DIS- } \\
\text { SOLVEO } \\
\text { (MG/L } \\
\text { AS MG) }\end{array}$ & $\begin{array}{l}\text { SUDIUM, } \\
\text { DIS- } \\
\text { SOLVED } \\
\text { (MG/L } \\
\text { AS NA) }\end{array}$ & $\begin{array}{l}\text { POTAS- } \\
\text { SIUM, } \\
\text { DIS-" } \\
\text { SOLVED } \\
\text { (MG L } \\
\text { AS K) }\end{array}$ \\
\hline M1 0.4 & $\begin{array}{l}77-06-15 \\
78-03-23 \\
78=03-30\end{array}$ & $\begin{array}{l}1400 \\
1400 \\
1215\end{array}$ & $\begin{array}{l}2.3 \\
18 \\
4.3\end{array}$ & $\begin{array}{l}205 \\
100 \\
124\end{array}$ & $\begin{array}{l}6.8 \\
7.2 \\
7.2\end{array}$ & $\begin{array}{r}21.0 \\
11.0 \\
11.5\end{array}$ & $\begin{array}{l}66 \\
27 \\
51\end{array}$ & $\begin{array}{l}7 \\
0 \\
4\end{array}$ & $\begin{array}{l}15 \\
5.9 \\
12\end{array}$ & $\begin{array}{l}6.9 \\
2.9 \\
5.1\end{array}$ & $\begin{array}{l}3.1 \\
.0 \\
1.3\end{array}$ & $\begin{array}{l}11 \\
9.5 \\
6.2\end{array}$ \\
\hline M5. 8 & $\begin{array}{l}77-0 b-15 \\
78-03-22 \\
78-03-30\end{array}$ & $\begin{array}{l}1100 \\
1700 \\
1100\end{array}$ & $\begin{array}{c}1.7 \\
16^{-0}\end{array}$ & $\begin{array}{l}890 \\
240 \\
255\end{array}$ & $\begin{array}{l}7.5 \\
7.1 \\
7.4\end{array}$ & $\begin{array}{r}20.5 \\
1.0 \\
3.0\end{array}$ & $\begin{array}{r}330 \\
84 \\
99\end{array}$ & $\begin{array}{r}210 \\
24 \\
32\end{array}$ & $\begin{array}{l}66 \\
19 \\
23\end{array}$ & $\begin{array}{l}40 \\
8.9 \\
10\end{array}$ & $\begin{array}{l}66 \\
11 \\
11\end{array}$ & $\begin{array}{l}6.1 \\
8.7 \\
6.2\end{array}$ \\
\hline M4. 5 & $78-03-29$ & 1000 & - & -- & 7.5 & $\cdots$ & 68 & 11 & 16 & 0.7 & 9.1 & 7.7 \\
\hline Mo. 0 & $\begin{array}{l}77-06-16 \\
78=03-22 \\
78=03-23 \\
78=03-30\end{array}$ & $\begin{array}{l}0945 \\
1345 \\
1400 \\
1345\end{array}$ & $\begin{array}{r}5.4 \\
78^{-.} \\
--\end{array}$ & $\begin{array}{r}180 \\
140 \\
90 \\
200\end{array}$ & $\begin{array}{l}7.5 \\
7.4 \\
7.2 \\
7.7\end{array}$ & $\begin{array}{r}16.0 \\
.2 \\
10.0 \\
9.3\end{array}$ & $\begin{array}{l}64 \\
32 \\
27 \\
72\end{array}$ & $\begin{array}{r}2 \\
0 \\
0 \\
12\end{array}$ & $\begin{array}{r}17 \\
7.5 \\
5.9 \\
17\end{array}$ & $\begin{array}{l}5.2 \\
3.3 \\
2.9 \\
7.1\end{array}$ & $\begin{array}{l}7.4 \\
5.9 \\
.6 \\
8.8\end{array}$ & $\begin{array}{l}11 \\
10 \\
9.5 \\
7.4\end{array}$ \\
\hline T8 & $76-03-29$ & 1110 & - & 770 & 8.0 & 7.5 & 280 & 110 & 60 & 32 & 73 & 5.0 \\
\hline$T 7$ & $77-05-05$ & 1100 & -- & -- & 8.4 & 10.0 & 91 & 19 & 25 & 7.0 & 13 & 10 \\
\hline
\end{tabular}

\begin{tabular}{|c|c|c|c|c|c|c|c|c|c|c|c|c|}
\hline SITE NUMBER & $\begin{array}{l}\text { DATE } \\
\text { UF } \\
\text { SAMPLE }\end{array}$ & $\begin{array}{c}\text { BICAR- } \\
\text { BUNATE } \\
\text { (MG/L } \\
\text { AS } \\
\text { HCUS) }\end{array}$ & $\begin{array}{l}\text { CAR- } \\
\text { BONAIE } \\
\text { (MG/L } \\
\text { AS CUS) }\end{array}$ & $\begin{array}{l}\text { ALKA: } \\
\text { LINITY } \\
\text { FIELL } \\
\text { (MG/L } \\
\text { AS } \\
\text { CACOS) }\end{array}$ & $\begin{array}{l}\text { SULFATE } \\
\text { OIS- } \\
\text { SOLVEU } \\
\text { (MG/L } \\
\text { AS SO4) }\end{array}$ & $\begin{array}{l}\text { CHLO- } \\
\text { RIUE, } \\
\text { OIS- } \\
\text { SOLVEO } \\
\text { (MLIL } \\
\text { AS CL) }\end{array}$ & $\begin{array}{l}\text { FLUO- } \\
\text { RIUE: } \\
\text { OIS: } \\
\text { SOLVED } \\
\text { (MG L } \\
\text { AS F) }\end{array}$ & $\begin{array}{l}\text { SILICA, } \\
\text { OIS- } \\
\text { SOLVED } \\
\text { (MG/L } \\
\text { AS } \\
\text { SIOL2) }\end{array}$ & $\begin{array}{l}\text { SOLIUS, } \\
\text { RESIOUE } \\
\text { AT } 180 \\
\text { OEG.C } \\
\text { UIS- } \\
\text { SOLVEO } \\
\text { (MG/L) }\end{array}$ & $\begin{array}{l}\text { SUL IUS, } \\
\text { SUM UF } \\
\text { CONSTI- } \\
\text { TUENTS, } \\
\text { DIS- } \\
\text { SULVED } \\
\text { (MG/L) }\end{array}$ & $\begin{array}{l}\text { NIIKU- } \\
\text { GEN, } \\
\text { NOZ+ND3 } \\
\text { OIS- } \\
\text { SOLVEU } \\
\text { (MG } \\
\text { AS N) }\end{array}$ & $\begin{array}{l}\text { NITHO- } \\
\text { GEN, AM- } \\
\text { MONIA } \\
\text { ORGANIC } \\
\text { OIS. } \\
\text { (MGIL } \\
\text { AS N) }\end{array}$ \\
\hline M10.4 & $\begin{array}{l}77=06-15 \\
78=05-23 \\
78=03-30\end{array}$ & $\begin{array}{l}72 \\
42 \\
57\end{array}$ & $\begin{array}{l}0 \\
0 \\
0\end{array}$ & & ${ }_{12}^{17} 7.5$ & $\begin{array}{l}2.0 \\
1.9 \\
1.3\end{array}$ & $\begin{array}{l}+1 \\
<1 \\
<1\end{array}$ & $\begin{array}{l}11 \\
6.1 \\
7.8\end{array}$ & $\begin{array}{rr}134 & \\
& \ldots \\
& \end{array}$ & $\begin{array}{l}104 \\
55.0 \\
74.0\end{array}$ & .30 & $\begin{array}{l}.93 \\
2.5 \\
.70\end{array}$ \\
\hline M5. 8 & $\begin{array}{l}77-0 b-15 \\
78-0 s-22 \\
70-0 s-30\end{array}$ & $\begin{array}{r}150 \\
74 \\
81\end{array}$ & $\begin{array}{l}0 \\
0 \\
u\end{array}$ & & $\begin{array}{r}330 \\
53 \\
56\end{array}$ & $\begin{array}{l}3.0 \\
2.3 \\
1.8\end{array}$ & $\begin{array}{l}.2 \\
<.1 \\
.1\end{array}$ & $\begin{array}{l}8.0 \\
5.7 \\
7.6\end{array}$ & $626 \quad \ldots$ & $\begin{array}{l}595 \\
106 \\
156\end{array}$ & $\begin{array}{r}.21 \\
-- \\
--\end{array}$ & $\begin{array}{l}.41 \\
1.3 \\
.05\end{array}$ \\
\hline M4. 5 & $78-05-29$ & 69 & 0 & & 34 & 1.8 & $<.1$ & 7.5 & $\cdots$ & 117 & -- & .97 \\
\hline Mo. 0 & $\begin{array}{l}77=06-16 \\
78=03-22 \\
78-03-23 \\
78=03-30\end{array}$ & $\begin{array}{l}75 \\
55 \\
42 \\
73\end{array}$ & $\begin{array}{l}0 \\
0 \\
u \\
u\end{array}$ & & $\begin{array}{l}17 \\
15 \\
7.5 \\
34\end{array}$ & $\begin{array}{l}3.1 \\
2.5 \\
1.9 \\
1.8\end{array}$ & $\begin{array}{l}i 1 \\
<1 \\
<1 \\
<1\end{array}$ & $\begin{array}{l}6.3 \\
4.8 \\
6.1 \\
7.5\end{array}$ & $136 \begin{array}{c}\ldots \\
\ldots \\
0\end{array}$ & $\begin{array}{l}107 \\
76.0 \\
55.0 \\
120\end{array}$ & $\begin{array}{l}.43 \\
\because- \\
--\end{array}$ & $\begin{array}{l}.39 \\
2.4 \\
2.5 \\
.89\end{array}$ \\
\hline T8 & $78-03-29$ & 210 & 0 & & 250 & 2.8 & .1 & 10 & $\cdots$ & 538 & $\cdots$ & .61 \\
\hline$T 7$ & $77=05-05$ & 80 & 0 & & 42 & 2.1 & .1 & 7.4 & 178 & 154 & .55 & 1.5 \\
\hline
\end{tabular}

\begin{tabular}{|c|c|c|c|c|c|c|c|c|c|c|c|c|}
\hline SITE NUMBER & $\begin{array}{l}\text { OAIE } \\
\text { UF } \\
\text { SAMPLE }\end{array}$ & $\begin{array}{l}\text { CARBUN, } \\
\text { UKGANIC } \\
\text { OIS- } \\
\text { SULVED } \\
\text { (MG/L } \\
\text { AS C) }\end{array}$ & $\begin{array}{l}\text { PHUS- } \\
\text { PHURUS, } \\
\text { UIS- } \\
\text { SULVEU } \\
\text { (MG/L } \\
\text { AS P) }\end{array}$ & $\begin{array}{l}\text { ALUM- } \\
\text { INUM, } \\
\text { OIS: } \\
\text { SOLVED } \\
\text { (UGAL } \\
\text { AS AL) }\end{array}$ & $\begin{array}{l}\text { ARSENIC } \\
\text { DIS- } \\
\text { SULVED } \\
\text { (UG/L } \\
\text { AS AS) }\end{array}$ & $\begin{array}{l}\text { BARIUM, } \\
\text { OIS- } \\
\text { SOLVEO } \\
\text { (UE/L } \\
\text { AS BA) }\end{array}$ & $\begin{array}{l}\text { BERYL- } \\
\text { LIUM, } \\
\text { UIS- } \\
\text { SOLVEU } \\
\text { (UG GL } \\
\text { AS OES) }\end{array}$ & $\begin{array}{l}\text { BORON, } \\
\text { OIS- } \\
\text { SOLVEU } \\
\text { (UG/L } \\
\text { AS O O) }\end{array}$ & $\begin{array}{l}\text { CAUMIUM } \\
\text { UIS- } \\
\text { SOLVEU } \\
\text { (UG/L } \\
\text { AS CU) }\end{array}$ & $\begin{array}{l}\text { CHKO- } \\
\text { MIUM, } \\
\text { DIS- } \\
\text { SOLVEO } \\
\text { (UG GL } \\
\text { AS CK) }\end{array}$ & $\begin{array}{l}\text { CUBALI, } \\
\text { UIS- } \\
\text { SOLVED } \\
\text { (UG/L } \\
\text { AS CU) }\end{array}$ & $\begin{array}{l}\text { CUPPER, } \\
\text { UIS- } \\
\text { SOLVEO } \\
\text { (UG/L } \\
\text { AS CU) }\end{array}$ \\
\hline$M 10.4$ & $\begin{array}{l}77-06-15 \\
78-03-23 \\
78-03-30\end{array}$ & ${ }^{21}=$ & $\begin{array}{r}.600 \\
-.-\end{array}$ & $\begin{array}{r}200 \\
40 \\
<100\end{array}$ & -3 & $\begin{array}{r}<100 \\
\because-\end{array}$ & \begin{tabular}{l}
$<10$ \\
\hdashline-
\end{tabular} & $\begin{array}{r}100 \\
80 \\
50\end{array}$ & $\begin{array}{l}\text { NU } \\
\therefore- \\
-.\end{array}$ & $\begin{array}{l}\text { NO } \\
\therefore- \\
\therefore-\end{array}$ & $\begin{array}{l}\text { NO } \\
--\end{array}$ & 11 \\
\hline M5. 8 & $\begin{array}{l}77-06-15 \\
78-03-22 \\
78-03-30\end{array}$ & $\begin{array}{l}9.5 \\
-.5\end{array}$ & $\begin{array}{r}100 \\
--\end{array}$ & $\begin{array}{r}20 \\
<100 \\
20\end{array}$ & $\begin{array}{l}1 \\
--\end{array}$ & $\begin{array}{r}<100 \\
\because- \\
-\end{array}$ & 5 & $\begin{array}{r}120 \\
70 \\
60\end{array}$ & $\begin{array}{l}<2 \\
\therefore\end{array}$ & $\begin{array}{l}<20 \\
\because-\end{array}$ & NO & $\frac{3}{-2}$ \\
\hline M4. 5 & $18-03-29$ & -- & -- & 20 & - & -- & -- & 70 & -- & -- & - & -- \\
\hline MO. 0 & $\begin{array}{l}77-06-16 \\
78-03-22 \\
78-05-23 \\
78-03-30\end{array}$ & ${ }^{24}=$ & $\begin{array}{r}.370 \\
-. \\
- \\
-\end{array}$ & $\begin{array}{r}260 \\
30 \\
40 \\
<100\end{array}$ & $\begin{array}{c}2 \\
\because- \\
\cdots\end{array}$ & \begin{tabular}{r}
$<100$ \\
\hdashline- \\
-
\end{tabular} & $\begin{array}{l}<10 \\
\because- \\
\because-\end{array}$ & $\begin{array}{r}120 \\
90 \\
80 \\
00\end{array}$ & $\begin{array}{l}<2 \\
\because \\
\because\end{array}$ & $\begin{array}{l}<20 \\
\because- \\
--\end{array}$ & $\begin{array}{l}\text { Nu } \\
\because- \\
\because-\end{array}$ & $\begin{array}{l}18 \\
\because- \\
\because-\end{array}$ \\
\hline T8 & $78-05-29$ & -- & -. & $<100$ & - & -- & -- & 90 & -- & -- & -- & -- \\
\hline T7 & $77=05=05$ & 16 & .510 & 210 & 2 & $<100$ & $<10$ & 90 & $<2$ & ND & ND & 6 \\
\hline
\end{tabular}

\begin{tabular}{|c|c|c|c|c|c|c|c|c|c|c|c|c|}
\hline SITE NUMBER & $\begin{array}{l}\text { DAIE } \\
\text { UF } \\
\text { SAMPLE }\end{array}$ & $\begin{array}{l}\text { IRUN, } \\
\text { UIS- } \\
\text { SULVEU } \\
\text { (UGIL } \\
\text { AS FE) }\end{array}$ & $\begin{array}{l}\text { LEAD, } \\
\text { DIS- } \\
\text { SOLVEU } \\
(U G / L \\
\text { AS PB) }\end{array}$ & $\begin{array}{l}\text { LITHIUM } \\
\text { UIS- } \\
\text { SOLVEU } \\
\text { (UGIL } \\
\text { AS LI) }\end{array}$ & $\begin{array}{l}\text { MANGA- } \\
\text { NESE, } \\
\text { OIS- } \\
\text { SULVED } \\
\text { (UG L } \\
\text { AS MN) }\end{array}$ & $\begin{array}{c}\text { MERCUKY } \\
\text { OIS- } \\
\text { SULVEO } \\
\text { (UGAL } \\
\text { AS HG) }\end{array}$ & $\begin{array}{l}\text { MULYB- } \\
\text { OENUM, } \\
\text { UIS- } \\
\text { SULVEU } \\
\text { (UG/L } \\
\text { AS MU) }\end{array}$ & $\begin{array}{l}\text { NICKEL, } \\
\text { UIS- } \\
\text { SULVEU } \\
\text { (UG } \\
\text { AS NI) }\end{array}$ & $\begin{array}{l}\text { SELE- } \\
\text { NIUM, } \\
\text { OIS- } \\
\text { SOLVED } \\
\text { (UG/L } \\
\text { AS SE) }\end{array}$ & $\begin{array}{l}\text { SIRUN- } \\
\text { TIUM. } \\
\text { OIS- } \\
\text { SOLVEO } \\
\text { (UG/L } \\
\text { AS SK) }\end{array}$ & $\begin{array}{l}\text { VANA- } \\
\text { OIUMA } \\
\text { DIS- } \\
\text { SOLVED } \\
\text { (UGAL } \\
\text { AS V) }\end{array}$ & $\begin{array}{l}\text { ZINC, } \\
\text { OIS- } \\
\text { SULVED } \\
\text { (UG } \\
\text { AS ZN) }\end{array}$ \\
\hline M10.4 & $\begin{array}{l}77=06-15 \\
78=03-23 \\
78=03-30\end{array}$ & $\begin{array}{l}220 \\
140 \\
110\end{array}$ & -3 & 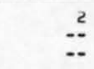 & $\begin{array}{r}r 10 \\
30 \\
<10\end{array}$ & $<5$ & $\begin{array}{r}41 \\
1 \\
1\end{array}$ & $\begin{array}{l}a \\
\therefore\end{array}$ & $\begin{array}{l}1 \\
\because-\end{array}$ & $\begin{array}{l}80 \\
80 \\
90\end{array}$ & $\begin{array}{r}3.0 \\
-. \\
-.\end{array}$ & $\begin{array}{r}<0 \\
--\end{array}$ \\
\hline M5. 8 & $\begin{array}{l}77=06-15 \\
78=03-22 \\
78=03-30\end{array}$ & $\begin{array}{r}50 \\
110 \\
330\end{array}$ & -5 & $\begin{array}{l}30 \\
\cdots \\
\cdots\end{array}$ & $\begin{array}{l}20 \\
50 \\
50\end{array}$ & $4: 5$ & $\begin{array}{r}<1 \\
1 \\
1\end{array}$ & $\begin{array}{l}2 \\
-2\end{array}$ & $\begin{array}{l}<1 \\
\because-\end{array}$ & $\begin{array}{l}560 \\
180 \\
180\end{array}$ & $\therefore 4$ & NO \\
\hline M4. 5 & $78-03-29$ & 100 & $\cdots$ & $\cdots$ & $<10$ & $\cdots$ & $<1$ & $\cdots$ & $\cdots$ & 190 & $\cdots$ & $\cdots$ \\
\hline MO. 0 & $\begin{array}{l}77=06-16 \\
78-03-22 \\
78=03-23 \\
78=03-30\end{array}$ & $\begin{array}{l}220 \\
120 \\
140 \\
100\end{array}$ & $\begin{array}{l}5 \\
-- \\
--\end{array}$ & $\begin{array}{l}<0 \\
\because- \\
--\end{array}$ & $\begin{array}{r}100 \\
20 \\
30 \\
20\end{array}$ & $\begin{array}{l}\because 5 \\
\therefore \\
\therefore\end{array}$ & $\begin{array}{r}<1 \\
1 \\
1 \\
1\end{array}$ & $\begin{array}{l}7 \\
-\therefore \\
--\end{array}$ & $\therefore$ & $\begin{array}{r}100 \\
90 \\
80 \\
140\end{array}$ & $\because 0$ & $\begin{array}{r}<0 \\
-\because \\
--\end{array}$ \\
\hline$T 8$ & $78-03-29$ & 40 & $\cdots$ & $\cdots$ & $<10$ & $\cdots$ & $<1$ & $\cdots$ & $\cdots$ & 500 & -- & $\cdots$ \\
\hline T7 & $77-05=05$ & 210 & 8 & $<10$ & 190 & $<.5$ & $<1$ & 6 & 1 & 80 & 4.0 & 20 \\
\hline
\end{tabular}


Water at site $M 10.4$ was a calcium-magnesium bicarbonate type for all samples analyzed (fig. 24). Calcium never exceeded 50 percent and magnesium never exceeded 35 percent of the cations, and bicarbonate never exceeded 80 percent of the anions. Water quality did not vary significantly between snowmelt runoff and rainfall runoff. Dissolved-solids concentrations remained relatively small, ranging from 55 to $134 \mathrm{mg} / \mathrm{L}$.

The snowmelt water at site M5.8 was a calcium-magnesium bicarbonate type. Although the discharge varied by about one order of magnitude between samples, the snowmelt runoff remained quite similar in composition, with calcium never exceeding 45 percent and magnesium never exceeding 35 percent of the cations, and with bicarbonate never exceeding 55 percent and sulfate never exceeding 46 percent of the anions. The dissolved-solids concentrations in these samples were $146 \mathrm{mg} / \mathrm{L}$ and $156 \mathrm{mg} / \mathrm{L}$. The quality of water resulting from rainfall on June 15, 1978, was significantly different from the snowmelt sample of March 22 , 1978 , even though stream discharge was about the same. In the rainfall runoff sample, calcium and magnesium comprised 34 percent of the cations each, bicarbonate comprised 26 percent of the anions, and sulfate 73 percent. The dissolved-solids concentration was $626 \mathrm{mg} / \mathrm{L}$, which was much greater than for snowmelt runoff. The variation between rainfall and snowmelt runnoff samples probably was due to increased amounts of ground water entering the stream, either spatially between sites $M 5.8$ and M10.4, temporally due to the resumption of infiltration after the ground thawed, or both.

Water in West Branch Antelope Creek at site M0.0 was a calcium bicarbonate or a calcium-magnesium bicarbonate type for all samples analyzed. Calcium never exceeded 53 percent of the cations, and magnesium never exceeded 43 percent of the cations. water quality at this site did not vary significantly between rainfall runoff and snowmelt runoff. Dissolved-solids concentrations were relatively small, remaining within a range between 55 and $120 \mathrm{mg} / \mathrm{L}$ and varied inversely with measured discharge.

The general trend of water quality in the West Branch Antelope Creek is illustrated in figure 25. The graphs are plots of the concentrations of the major dissolved constituents versus river miles. The increase in all the major constituents from site M10.4 to site M5.8 may show the effect of increased amounts of ground water entering the stream between these sites. A small decrease in the concentrations of the major dissolved constituents from site M5.8 to site M0.0 may be due to dilution.

Suspended sediment samples were collected for a runoff period during June 1977 and for several periods of runoff during 1978. The sediment concentrations vary for a given discharge by one to two orders of magnitude (table 11). This variability precludes 


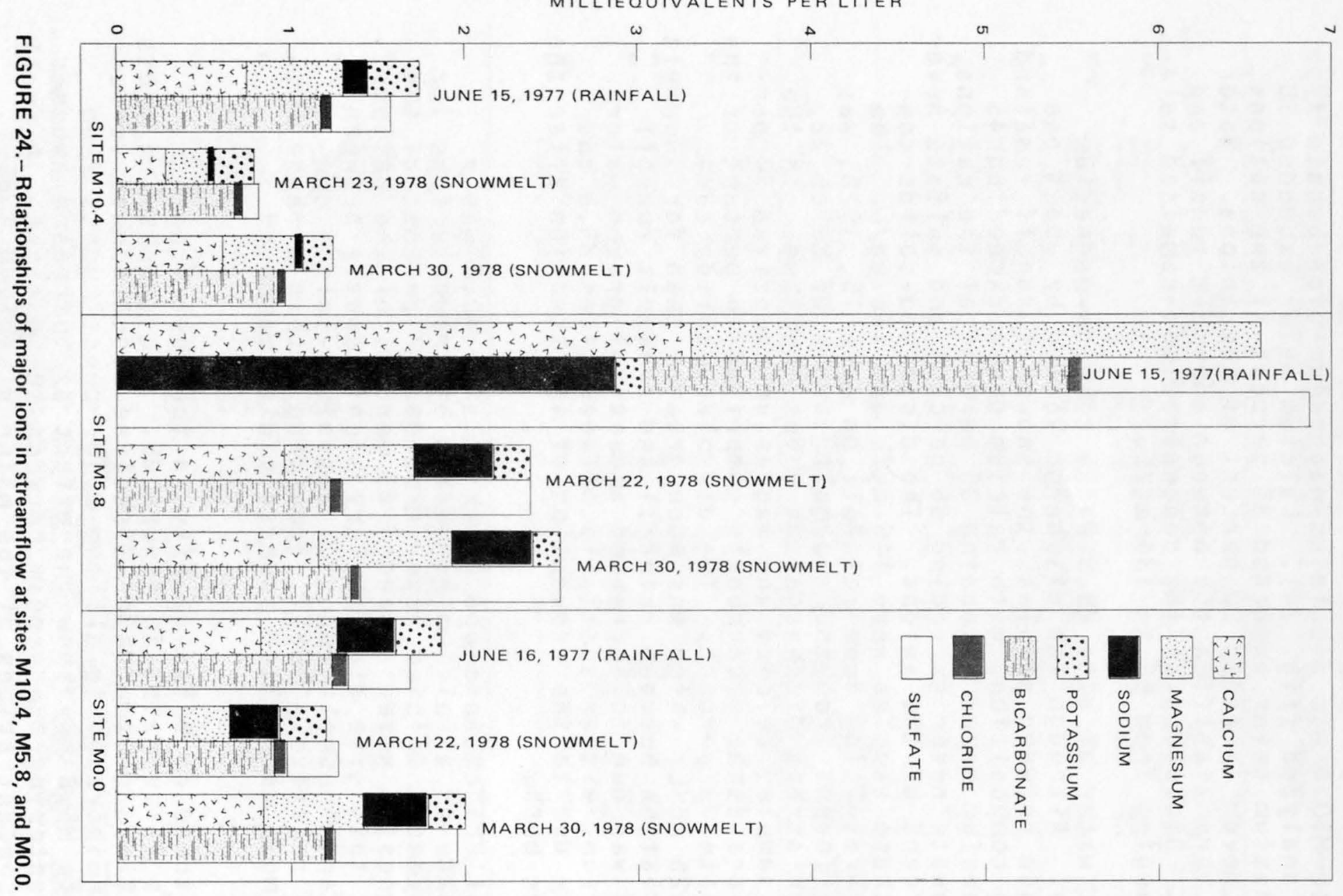



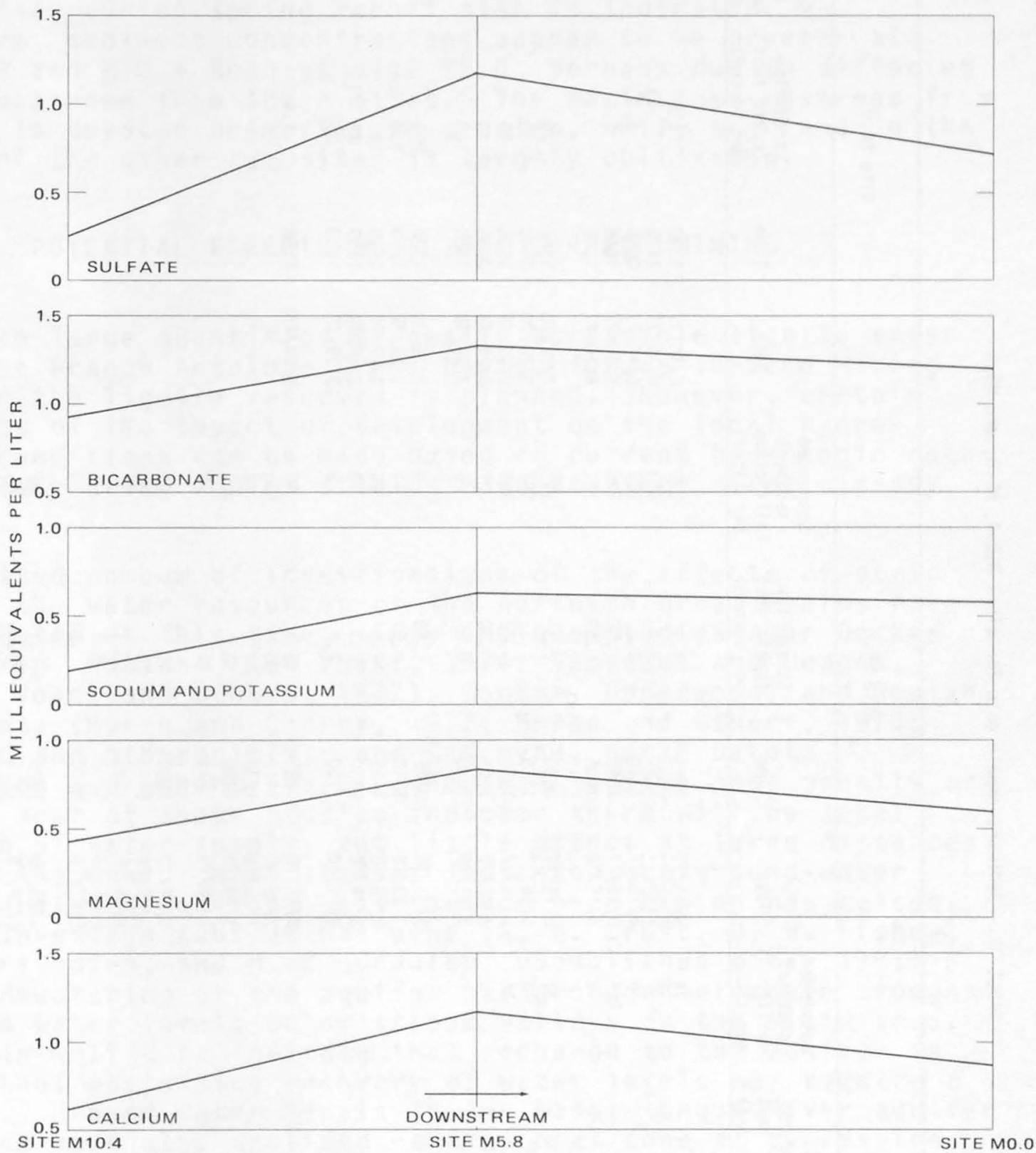

FIGURE 25.-Concentrations of dissolved constituents in streamflow at sites M10.4, M5.8, and M0.0 for March 30, 1978. 
TABLE 11.--Sediment-sample data for sites M10.4, M5.8, and M0.0

Site $M 10.4$

\begin{tabular}{lcc}
\hline Date & Time & $\begin{array}{c}\text { Streamflow } \\
\text { (cubic fe } \\
\text { per second) }\end{array}$ \\
\hline & & \\
$3 / 23 / 78$ & 1345 & 18 \\
$3 / 24 / 78$ & 1010 & 41 \\
$3 / 25 / 78$ & 1425 & 43 \\
$3 / 26 / 78$ & 1445 & 72 \\
$3 / 27 / 78$ & 1315 & 41 \\
$3 / 28 / 78$ & 1220 & 7.6 \\
$3 / 29 / 78$ & 1355 & 7.0 \\
$3 / 30 / 78$ & 1235 & 7.3 \\
$4 / 04 / 78$ & 1105 & 1.8 \\
$5 / 02 / 78$ & 0805 & .01
\end{tabular}

Site $M 5.8$

\begin{tabular}{|c|c|c|c|}
\hline $\begin{array}{c}\text { Suspended } \\
\text { sediment } \\
\text { (milligrams } \\
\text { per liter) }\end{array}$ & Date & Time & $\begin{array}{l}\text { Streamflow } \\
\text { (cubic feet } \\
\text { per second) }\end{array}$ \\
\hline
\end{tabular}

Suspended

sediment milliarams per liter)

$\begin{array}{ll}6 / 15 / 77 & 1055 \\ 6 / 15 / 77 & 1200 \\ 6 / 15 / 77 & 1310 \\ 6 / 15 / 77 & 1340 \\ 6 / 15 / 77 & 1435\end{array}$

1.9

1.9
1.3
1.2

1.2

.59

$6 / 16 / 77$

\section{$6 / 16 / 77$}

$6 / 16 / 77$

$3 / 22 / 78$

0850

1115
1355

1555

$3 / 22 / 78 \quad 1630$

$3 / 23 / 78 \quad 0745$

$3 / 23 / 78$

$3 / 23 / 78$

$3 / 24 / 78$

$3 / 24 / 78$

$3 / 25 / 78 \quad 1225$

$3 / 25 / 78 \quad 1445$

$3 / 26 / 78 \quad 1230$

$3 / 28 / 78$

$3 / 28 / 78$

$3 / 29 / 78 \quad 1230$

$3 / 30 / 78$

$4 / 04 / 78$

$4 / 05 / 78$

$5 / 02 / 78$

$6 / 29 / 78$

$6 / 29 / 78$

$6 / 29 / 78$

$9 / 12 / 78$
1015

1455

0930

1150

1230
1020

1315

1145
1035

1035
1200

0930

1625

1715

1740
1045

Site MO.0

Date Time $\quad \begin{aligned} & \text { Streamflow } \\
& \text { (cubic feet } \\
& \text { per second) }\end{aligned} \quad$\begin{tabular}{c}
$\begin{array}{c}\text { Suspended } \\
\text { sediment } \\
\text { (milligrams } \\
\text { per liter) }\end{array}$ \\
\hline
\end{tabular}

$\begin{array}{rrrcr}230 & 6 / 15 / 77 & 1030 & 2.0 & 1,180 \\ 158 & 6 / 15 / 77 & 1525 & .49 & 914 \\ 134 & 6 / 16 / 77 & 0855 & 6.3 & 191 \\ 126 & 6 / 16 / 77 & 1045 & 5.4 & 748 \\ 122 & 6 / 16 / 77 & 1345 & 3.5 & 730 \\ 191 & 3 / 22 / 78 & 1350 & 78 & \\ 167 & 3 / 23 / 78 & 0940 & 50 & 524 \\ 180 & 3 / 23 / 78 & 1535 & 80 & 44 \\ 21 & 3 / 24 / 78 & 0855 & 140 & 166 \\ 26 & 3 / 24 / 78 & 1300 & 140 & 32 \\ & & & & 135 \\ 9 & 3 / 25 / 78 & 1500 & 213 & \\ 11 & 3 / 26 / 78 & 1250 & 160 & 277 \\ 26 & 3 / 27 / 78 & 1630 & 191 & 292 \\ 10 & 3 / 28 / 78 & 1430 & 74 & 139 \\ 9 & 3 / 29 / 78 & 1110 & 36 & \\ 50 & 4 / 04 / 78 & 1155 & 1.4 & \end{array}$


quantitative conclusions, but the data indicate an approximately inverse relationship between concentration and discharge during spring runoff. A greater contribution of sediment during summer rainfall than during spring runoff also is indicated.

Furthermore, sediment concentrations appear to be greater at sites M0.0 and $M 10.4$ than at site M5.8, perhaps due to differing 1 and use upstream from these sites. The basin just upstream from site M5.8 is devoted primarily to grazing, while the land in the vicinity of the other two sites is largely cultivated.

\section{POTENTIAL EFFECTS OF FUTURE SURFACE MINING}

Because large quantities of easily accessible lignite exist in the West Branch Antelope Creek basin, future surface mining to recover the 1 ignite reserves is planned. However, certain predictions of the impact of development on the local hydrogeologic conditions can be made based on current hydrologic data for the study area, and on studies made at other sites already mined.

A 1 imited number of investigations of the effects of strip mining on the water resources of the northern Great Plains have been completed at this time. They include studies near Decker and Colstrip, Montana (Van Voast, 1974; VanVoast and Hedges, 1975; Van Voast and others, 1977); Center, Underwood, and Beulah, North Dakota (Moran and Cherry, 1977; Moran and others, 1978; Groenewold and others 1979); and Gascoyne, North Dakota

(Thorstenson and others, 1979). Because lignite beds usually are aquifers, most of these studies indicate there will be local disruption of water supply, but little effect at large distances away from the mine. Most studies indicate that ground-water levels and flow directions will recover once mining has ceased. However, investigations at Gascoyne (M. G. Croft, D. W. Fisher, D. C. Thorstenson, and M. E. Crawley, unpublished data, 1981) indicate dewatering of the aquifer has produced elongate troughs of lowered water levels below stream valleys in the mined area. observation-well data indicate that recharge to the aquifer is minimal, thus postmining recovery of water levels may require a long time. Ground-water levels in the basal Tongue River aquifer at Gascoyne have also declined, and a local cone of depression has formed beneath the mine due to the dewatering. Movement of water has been attributed to blasting, which has greatly increased vertical permeabilities in the sandstone beneath the mine area.

Surface- and ground-water quality in the immediate vicinity of surface-mining operations in the northern Great Plains has been shown to be degraded by increased concentrations of sulfate and dissolved solids. Locally, increases in pH, and in concentrations of hydrogen sulfide, sodium, bicarbonate, iron, or fluoride also may occur. 
These observations from the surface-mining operations provide a basis for evaluating probable future mining effects in the Antelope creek tributary area.

\section{Ground-Water Flow}

Future strip mining of coal reserves owned by the Federal government probably will begin on the western edge of the West Branch Antelope Creek tributary valley. The western edge of the valley represents the local terminus for the ground-water-flow system in the Beulah-zap lignite and shallow water-table aquifers above the coal. Stripping of overburden and removal of coal would result in increased discharge from the lignite and other shallow aquifers. Recharge to the shallow water-table aquifers above the coal is from direct infiltration of precipitation. Recharge to the lignite aquifers is from downward leakage from the shallow aquifers. In areas where thick bedrock or glacial till overlie the Beulah-zap lignite, recharge and vertical movement of precipitation to the lignite aquifer is very slow. This slow vertical movement, coupled with the increased water withdrawals at a mine site could lower water levels significantly in areas upgradient from a new mine site. However, the apparent minimal permeability of the lignite and clay-silt bedrock of the Sentinel Butte may decrease or at least delay the decline in water levels at large distances away from a proposed mine site. It is reasonable to assume that significant deciines in water levels in wells in lignite and shallower aquifers would not extend more than 1 to 2 miles from an active mine site.

Water levels in deeper aquifers would not be adversely affected, because the hydraulic heads are lower in progressively deeper aquifers. However, mining and dewatering of shallow aquifers would result in changes in hydraulic gradients and a reduction in local recharge to aquifers beneath the Beulah-Zap lignite.

\section{Ground-Water Quality}

The chemistry of ground water in areas of strip mining in the northern Great Plains is being studied in detail at several 1ocations. To accurately determine the effects of strip mining on water quality, a premining data base needs to be established in areas of proposed mining. Resampling of wells after mining has begun will indicate if there is any alteration of water chemistry due to mining. A brief discussion of the effects of mining on water quality at Gascoyne, based on the unpublished study of Croft and others, is presented here to provide evidence as to possible effects in similar unmined areas such as the West Branch Antelope Creek basin. 
The Gascoyne study indicated that leachate from exposed spoils and from the mine pit walls and floor was rich in sulfate derived from dissolved gypsum. Ground-water samples from within the area of mining operation contained concentrations of sulfate of as much as $6,500 \mathrm{mg} / \mathrm{L}$ and sodium concentrations of as much as $2,900 \mathrm{mg} / \mathrm{L}$. The significant increases were attributed to oxidation of pyrite and dissolution of minerals and salts in exposed overburden and subsequent infiltration of this leachate into the shallow ground-water system. The characteristics of overburden at Gascoyne are similar to those of the Sentinel Butte material in West Branch Antelope Creek present study area; therefore, changes in ground-water chemistry could be similar to those determined at Gascoyne.

The geochemistry of overburden in the West Branch Antelope Creek study area has been discussed in detail in a previous section; therefore, only references to that section will be made here.

Normal dragline procedure results in the redeposition of materials in reverse order of their original state, except for the topsoil. Near-surface material is placed at the base of the spoil piles and deeper sediments on the surface. Sediments that contain soluble and exchangeable sodium would be deposited near the surface. Therefore, sediment that was deeply buried and at equilibrium with a reducing environment would be placed in an environment of rapid oxidation and alteration. Available pyrite would be oxidized quickly; however, the resulting acidity probably would be buffered by solution of carbonate minerals and subsequent cation exchange of divalent cations for sodium. Resultant leachate from spoil piles should then have large concentrations of sodium, bicarbonate, and sulfate and smaller concentrations of calcium and magnesium. Ground-water samples from shallow areas in reclaimed spoils at Gascoyne (M. G. Croft, oral commun., 1978) were a sodium sulfate type that had dissolvedsolids concentrations of as much as $24,000 \mathrm{mg} / \mathrm{L}$.

Geochemical studies of spoil-pile samples from mines in North Dakota indicated that leachate from spoils was more alkaline and contained considerably more soluble-salt material than did the leachate from natural topsoil from nearby locations (Sandoval and others, 1973). Sodium-adsorption ratios for spoil extracts ranged from 2 to 48 , with most large enough to indicate limited revegetation potential. Other analyses (Power and others, 1974) indicated that Paleocene shales from depths greater than 30 feet contained considerable exchangeable ammonium nitrogen. When these shales were exposed to the atmosphere, nitrification of exchangeable ammonium occurred resulting in increased soil nitrate content for a short period after mining.

Infiltration of precipitation that leaches through spoils may be expected to contain more dissolved material than normal ground 
or surface waters. Because strata exposed in mine pits are open to the same oxidation processes as affect the spoils, ground water seeping from exposed aquifers into mine pits may display a similar enrichment in dissolved constituents. Therefore, dissolved-solids concentrations in shallow ground water beneath mine sites may increase. If mine sites are located at or near the edge of the Antelope creek aquifer, it seems probable that shallow ground water in areas of the aquifer that are downgradient from the mine sites will become more mineralized with time.

The available geochemical and hydrologic data for the Sentinel Butte and Antelope Creek aquifers indicate that local small plumes of water rich in sodium and sulfate could result from mining along the edge of the West Branch Antelope Creek tributary valley. Present hydrologic data for the Antelope Creek aquifer indicate that the parts of the aquifer that lie in $T$. 145 , R. 88, secs. 13 and 24 are major recharge areas for the upper unit of the Antelope Creek aquifer. Effluent from strip pits or runoff from rain and snow that infiltrates through spoils could easily move into the shallow ground-water system in these areas. An extensive unit of fine-grained sediment that divides the aquifer into upper and basal units may prevent the transport of solute to the basal aquifer unit.

The quantity and nature of the clay minerals in both the Sentinel Butte and Antelope Creek aquifers would indicate that transport of trace metals would be greatly retarded by adsorption and cation exchange. Furthermore, the large bicarbonate concentration in ground and surface waters would produce rapid precipitation of most trace metals even though present in small concentrations. Thus, the potential for contamination of ground waters by toxic concentrations of trace metals for people would be very small. Solution and transport of toxic organics derived from coal could present a problem; however, no study in this field was found in the literature.

Further site-specific geochemical studies are necessary to make accurate predictions of the potential for the increase in concentration and transport of any given chemical species from a mine site to ground-water supplies.

\section{Surface-Water Flow}

The impacts of mining on the quantity and timing of runoff will be dependent on mining practices, but probably will be very minor. There could be some realignment of small tributaries of the main streams, but the overall drainage area should remain virtually unchanged. Alteration of existing stream channels to intercept and divert surface runnoff within the mining area could cause alterations in the existing flow regimen downstream. 
Because spoils or reclaimed areas probably will, at least initially, have greater infiltration capacity than undisturbed material, there would be decreased runoff from snowmelt or rainfall. With the increased permeability, there is the possibility of the development of springs. and consequent temporal extension of base flow in the streams. The overall flow regimen of West Branch Antelope Creek probably will be altered only slightly unless impoundments or other alterations are made on the mainstream.

Further study is planned on the effects of mining on surface runoff. Data collection will continue in this study area for several years; the objective will be to develop a surface-water model to evaluate the effects of changing land use.

\section{Surface-Water Quality}

Erosion and transportation of sediment will increase, at least initially, due to removal of vegetative cover from land contributing runoff to the streams. The sediment yield will depend on the mining practices--the development of sedimentation ponds, the stability of diversion channels, and the speed with which vegetative cover can be re-established. There should be little change in the chemical quality of water diverted around the active mining areas. However, runoff from the spoils, reclaimed areas, or both, probably will have increased salinity. Recharge to the streams will be affected by increased infiltration in spoils, and reclaimed land could be expected to have a greater than present salinity.

Further study is being made on the present water quality of the study area in conjunction with the study of surface runoff. Predictive capability of changes with altered land use will be explored as a part of the study.

\section{SUMMARY}

The proposed strip-mining activities in the West Branch Antelope Creek basin area will result in changes in the streamflow, ground-water, and geochemical regime.

The lignite beds and abundant discontinuous sandstone intervals of the Sentinel Butte Member and the glaciofluvial sand and gravel deposits supply most of the water for domestic and livestock water use. Generally, the sandstones occurring in the Sentinel Butte in the study area are unconsolidated, but they are poorly sorted and have a large clay content; therefore, they have relatively small porosity and permeability. Most of the 
sandstone occurs as a basal unit that has a variable thickness. The Beulah-Zap lignite bed forms a shallow confined aquifer on the western side of the study area. Permeability and groundwater flow in this lignite bed probably are controlled by fractures and joints. Ground water in the lignite and upper

sandstones of the sentinel Butte moves from the highlands area in the west toward the Antelope Creek aquifer. Ground-water levels in the basal Sentinel Butte sandstone appear to be controlled by the level of Lake Sakakawea.

The deposits forming the Antelope Creek aquifer consist of glaciofluvial sand and gravel interbedded with silt and clay. The deposits generally are unconsolidated and very permeable. Transmissivity at one location near the center of the aquifer exceeds 25,000 $\mathrm{ft}^{2} / \mathrm{d}$. Ground-water movement from the aquifer is northward to Lake Sakakawea and southward to the Knife River.

The water from the basal sandstone unit of the Sentinel Butte Member is a sodium bicarbonate type, and that from the Beulah-Zap lignite is a calcium-magnesium sulfate or a sodium bicarbonate type. The quality of water from the Antelope Creek aquifer is variable; water types ranged from calcium-magnesium bicarbonate to sodium bicarbonate.

West Branch Antelope Creek is, for the most part, an ephemeral stream with most of the flow occurring during the snowmelt period. Based on a regression analysis of the records of other streams in the area, the mean annual runoff from the area would be about 72 acre-feet per square mile.

The surface-water chemical analyses generally show calcium and magnesium as the dominant cations. The dominant anion is bicarbonate, though some samples had a relatively large concentration of sulfate. The quality generally did not vary significantly between snowmelt runoff and summer rainfall runoff.

Slow vertical movement of recharge water from precipitation, coupled with rapid water withdrawals at mine sites, could lower water levels significantly in areas upgradient from the mine. However, with the apparent minimal permeabilities of the bedrock, it is reasonable to assume that large declines would not extend more than 1 to 2 miles from the mine site. Water levels in the deeper aquifers should not be adversely affected by mining.

The Sentinel Butte Member is mineralogically complex and variable. Excluding carbonaceous and lignitic units, quartz comprises from 15 to 60 percent of the material. Carbonate mineral concentrations range from 1 to 45 percent. Clay minerals are very abundant; smectite and illite dominate.

From a single-core sample, leachates above the Beulah-Zap lignite were alkaline. The upper leachate samples were a 
calcium-magnesium bicarbonate type and the lower leachate samples were predominantly a sodium bicarbonate type. Leachate from the lignite was enriched in sodium and sulfate.

Data available indicate that small local plumes of water rich in sodium and sulfate could result from mining along the edge of the West Branch Antelope Creek tributary. In some locations there will be movement of this enriched water toward the Antelope Creek aquifer. The potential for contamination of ground waters by toxic concentrations of trace metals for people would be smal1. Transport would be greatly retarded by adsorption and cation exchange and the large bicarbonate concentration in the water would produce rapid precipitation of most trace metals.

The impact of the mining on the quantity and timing of runoff will probably be minor and will be dependent on mining practices. There would be major changes on small areas for short periods of time but the overall flow regimen would be altered only slightly.

Sediment yields will change depending on mining practices. Runoff from spoils, reclaimed areas, or both, will have increased salinity.

\section{SELECTED REFERENCES}

Alger, R. P., 1966, Interpretation of electric logs in freshwater wells in unconsolidated formations: Society of Professional Well Log Analysts Transactions, 7 th Annual Logging Symposium, sec. cc, p. 1-25.

Benson, W. E., 1952, Geology of the Knife River area, North Dakota: U.S. Geological Survey open-file report.

Bolt, G. H., and Bruggenwert, M. G. M., 1976, Composition of the soil, in Bolt, G. H., and Bruggenwert, M. G. M., eds., Soil chemistry--A. Basic elements: New York, Elsevier Scientific Publishing Company, p. 1-12.

Bradley, Edward, and Jensen, H. M., 1962, Test drilling near Beulah, Mercer County, North Dakota: North Dakota State Water Commission Ground-Water Studies No. 40, 19 p.

Busenberg, E., 1975, Incongruent dissolution of feldspars: Stanford University, unpublished Ph. D. dissertation.

Carlson, C. G., 1973, Geology of Mercer and 01 iver Counties, North Dakota: North Dakota Geological Survey Bulletin 56 , pt. I, and North Dakota State Water Commission County Ground-Water Studies 15, pt. I, 72 p. 
Cavancara, A. V., 1976, Geology of the Cannonball Formation

(Paleocene) in the Williston basin, with reference to

uranium potential: North Dakota Geological Survey Report

of Investigation No. $57,22 \mathrm{p}$.

Croft, M. G., 1970, Ground-water basic data, Mercer and 01 iver Counties, North Dakota: North Dakota Geological Survey

Bulletin 56, pt. II, and North Dakota State Water Commission County Ground-Water Studies 15, pt. II, 268 p.

1971, A method of calculating permeability from electric Togs: U.S. Geological Survey Professional Paper 750-B, p. $265-269$.

1973, Ground-water resources, Mercer and 01 iver Counties, North Dakota: North Dakota Geological Survey Bulletin 56 , pt. III, and North Dakota State Water Commission County Ground-Water Studies 15, pt. III, 81 p.

Crosby, 0. A., 1974, An investigation of basin effects on flood discharges in North Dakota: U.S. Geological Survey open-File Report 74-346, 49 p.

1975, Magnitude and frequency of floods in small drainage basins in North Dakota: U.S. Geological Survey Water Resources Investigations 19-75, $24 \mathrm{p}$.

Denson, N. M., and Gi11, J. R., 1965, Uranium-bearing lignite and carbonaceous shale in the southwestern part of the Williston basin--A regional study, with a section on Heavy minerals in cretaceous and Tertiary rocks associated with uranium occurrences, by W. A. Chisholm: U.S. Geological Survey Professional Paper 463, 75 p.

Garrels, R. M., and Mackenzie, F. T., 1967, Origin of the chemical compositions of some springs and lakes, in Gould, R. F., ed., Equilibrium concepts in naturat water systems: Washington, D.C., Advances in Chemistry, series 67 , p. $222-242$.

Groenewold, G. H., Hemish, L. A., Cherry, J. A., Rehm, B. W., Meyer, G. N., and Winczewski, L. M., 1979, Geology and geohydrology of the Knife River basin and adjacent areas of west-central North Dakota: North Dakota Geological Survey Report of Investigation No. 64, 402 p.

Hickey, L. V., 1966, The paleobotany and stratigraphy of the Golden Valley Formation in western North Dakota: Princeton University, unpublished Ph. D. thesis, $265 \mathrm{p}$. 
Jacob, A. F., 1975, Criteria for differentiating the Tongue River and Sentinel Butte Formations (Paleocene), North Dakota: North Dakota Geological Survey Report of Investigation $53,55 \mathrm{p}$.

Johnson, W. D., Jr., and Kunkel, R. P., 1959, The Square Buttes coal field, 01 iver and Mercer Counties, North Dakota: U.S. Geological Survey Bulletin 1076, 91 p.

Krauskopf, K. B., 1967, Introduction to geochemistry: New York, McGraw-Hill Publishing Company, 721 p.

Kume, Jack, and Hansen, D. E., 1965, Geology and ground-water resources of Burleigh County, North Dakota; pt. I, Geology: North Dakota Geological Survey Bulletin 42 and North Dakota State Water Commission County Ground-Water Studies $3,111 \mathrm{p}$.

Lloyd, E. R., and Hares, C. J., 1915, The Cannonball marine member of the Lance Formation of North and South Dakota and its bearing on the Lance-Laramide problem: Journal of Geology, v. 23, p. 523-547.

Mackenzie, R. C., 1963, Retention of exchangeable ions by montmorillonite, in Rosenquist, I. Th., and Graff Petersen, P., eds., International Clay Conference 1963, at Stockholm, Sweden, August 12-16: New York, Pergamon Press, Macmillan Company, p. 183-193.

Moran, S. R., and Cherry, J. A., 1977, Subsurface-water chemistry in mined-1and reclamation: Key to development of a productive post-mining landscape: Proceedings Second Annual General Meeting Canadian Land Reclamation Association, August 1977, Edmonton, Alberta, Paper No. 4, $29 \mathrm{p}$.

Moran, S. R., Groenewold, G. H., and Cherry, J. A., 1978, Geologic, hydrologic, and geochemical concepts and techniques in overburden characterization for mined-land reclamation: North Dakota Geological Survey Report of Investigation No. $63,152 \mathrm{p}$.

Papike, J.J., 1969, Pyroxenes and amphiboles: Crystal chemistry and phase petrology: Mineralogical Society of America Special Paper No. 2, 314 p.

Pipiringos, G. N., Chisholm, W. A., and Kepferle, R. C., 1965, Geology and uranium deposits in the Cave Hills area, Harding County, South Dakota: U.S. Geological Survey Professional Paper 476-A, $64 \mathrm{p}$. 
Power, J. F., Bond, J. J., Sandoval, F. M., and Willis, W. 0., 1974, Nitrification in Paleocene shales: Science 183: $1077-1079$.

Rehbein, E, A., 1978, Depositional environments and lignite resources of the Fort Union Formation, west-central North Dakota: Montana Geological Society 24 th Annual Conference, 1978 Williston basin symposium, The economic geology of the Williston basin, September 24-27, 1978, Billings, Montana, p. 295-305.

Renick, B. C., 1925, Base exchange in ground water by silicates as illustrated in Montana: U.S. Geological Survey WaterSupply Paper 520-D, p. 53-72.

Sandoval, F. M., Bond, J. J., Power, J. F., and Willis, W. 0., 1973, Some environmental aspects of strip mining in North Dakota: North Dakota Geological Survey Educational Series 5, $121 \mathrm{p}$.

Schultz, L. G., 1960, Quantitative X-ray determination of some aluminous clay minerals in rocks, in Swineford, Ada, ed., Clays and clay minerals: National Conference on Clays and Clay Minerals, $7 \mathrm{th}$, Washington, D.C., Dctober 1958, Proceedings, p. 216-224 (Issued as International Earth Science Series Monograph 5 of Pergamon Press, New York).

Stanton, T. W., 1920, The fauna of the Cannonball marine member of the Lance Formation: U.S. Geological Survey Professional Paper 128-A, p. 1-60.

Stewart, F. H., 1963, Marine evaporites: U.S. Geological Survey Professional Paper 440-Y, $52 \mathrm{p}$.

Swanson, V. E., Huffman, C., Jr., and Hamilton, J. C., 1974, Composition and trace element content of coal, northern Great Plains area, in Northern Great Plains Resource Program, Mineral Resources Work Group Report, February 1974: U.S. Department of the Interior Open-File Report, p. 52-83.

Tettenhorst, R., 1962, Cation migration in montmorillonites: American Mineralogist, v. 47, p. 769-773.

Thorstenson, D. C., Fisher, D. W., and Croft, M. G., 1979, The geochemistry of the Fox Hills-basal Hell Creek aquifer in southwestern North Dakota and northwestern South Dakota: Water Resources Research, vol. 15, no. 6, p. 1479-1498.

Truesdale, A. H., and Jones, B. F., 1974, WATEQ, A computer program for calculating chemical equilibria of natural waters: U.S. Geological Survey Journal of Research, v. 2 , no. 2, p. 233-248. 
U.S. Department of Agriculture, Soil Conservation Service, 1978, Soil survey of Mercer County, North Dakota: 223 p.

U.S. Environmental Data Service, 1960-79, Climatological data, North Dakota: U.S. Department of Commerce, National Oceanic and Atmsopheric Administration, Annual Summaries 1959-78, v. $68-87$, no. 13 .

1973, Montly normals of temperature, precipitation, and heating and cooling degree days, 1941-1970: U.S. Department of Commerce, National Oceanic and Atmospheric Administration Climatography of the United States, no. 81 (by state), North Dakota.

U.S. Salinity Laboratory Staff, 1954, Diagnosis and improvement of saline and alkali soils: U.S. Department of Agriculture, Agriculture Handbook No. 60, 160 p.

U.S. Weather Bureau, 1961, Rainfall frequency atlas of the United States: U.S. Weather Bureau Technical Paper No. $40,115 \mathrm{p}$.

Van Voast, W. A., 1974, Hydrologic effects of strip mining in southeastern Montana; Emphasis--One year of mining near Decker: Montana Bureau of Mines and Geology, Bulletin 93,24 p.

Van Voast, W. A., and Hedges, R. B., 1975, Hydrogeologic aspects of existing and proposed strip coal mines near Decker, southeastern Montana: Montana Bureau of Mines and Geology, Bulletin 97, $31 \mathrm{p}$.

Van Voast, W. A., Hedges, R. B., and McDermott, J. J., 1977, Hydrogeologic conditions and projections related to mining near Colstrip, southeastern Montana: Montana Bureau of Mines and Geology, Bulletin 102, 43 p.

Winchell, A. N., 1951, Elements of optical mineralogy, An introduction to microscopic petrography, pt. II, Descriptions of minerals: New York, John Wiley and Sons, Inc., $551 \mathrm{p}$. 
